\title{
Review \\ Mesenchymal Stem Cell-Derived Exosomes: Applications in Regenerative Medicine
}

\author{
Mangesh D. Hade, Caitlin N. Suire (D) and Zucai Suo *(D) \\ Department of Biomedical Sciences, College of Medicine, Florida State University, Tallahassee, FL 32306, USA; \\ mangesh.hade@med.fsu.edu (M.D.H.); csuire@fsu.edu (C.N.S.) \\ * Correspondence: zucai.suo@med.fsu.edu; Tel.: +1-(850)-645-2501
}

Citation: Hade, M.D.; Suire, C.N.; Suo, Z. Mesenchymal Stem Cell-Derived Exosomes: Applications in Regenerative Medicine. Cells 2021, 10, 1959. https://doi.org/10.3390/ cells10081959

Academic Editor: Mujib Ullah

Received: 30 June 2021

Accepted: 30 July 2021

Published: 1 August 2021

Publisher's Note: MDPI stays neutral with regard to jurisdictional claims in published maps and institutional affiliations.

Copyright: (c) 2021 by the authors. Licensee MDPI, Basel, Switzerland. This article is an open access article distributed under the terms and conditions of the Creative Commons Attribution (CC BY) license (https:// creativecommons.org/licenses/by/ $4.0 /)$.

\begin{abstract}
Exosomes are a type of extracellular vesicles, produced within multivesicular bodies, that are then released into the extracellular space through a merging of the multivesicular body with the plasma membrane. These vesicles are secreted by almost all cell types to aid in a vast array of cellular functions, including intercellular communication, cell differentiation and proliferation, angiogenesis, stress response, and immune signaling. This ability to contribute to several distinct processes is due to the complexity of exosomes, as they carry a multitude of signaling moieties, including proteins, lipids, cell surface receptors, enzymes, cytokines, transcription factors, and nucleic acids. The favorable biological properties of exosomes including biocompatibility, stability, low toxicity, and proficient exchange of molecular cargos make exosomes prime candidates for tissue engineering and regenerative medicine. Exploring the functions and molecular payloads of exosomes can facilitate tissue regeneration therapies and provide mechanistic insight into paracrine modulation of cellular activities. In this review, we summarize the current knowledge of exosome biogenesis, composition, and isolation methods. We also discuss emerging healing properties of exosomes and exosomal cargos, such as microRNAs, in brain injuries, cardiovascular disease, and COVID-19 amongst others. Overall, this review highlights the burgeoning roles and potential applications of exosomes in regenerative medicine.
\end{abstract}

Keywords: exosomes; extracellular vesicles; mesenchymal stem cells; regenerative medicine; microRNA; growth factors; wound healing; traumatic brain injury; cardiovascular disease; COVID-19

\section{Introduction}

Exosomes are membranous extracellular vesicles that range from 30-200 nm in diameter. Exosomes have been found to be secreted by most cell types including immune cells (B cells, T cells, mast cells, dendritic cells), neuronal cells, epithelial cells, endothelial cells, embryonic cells, cancer cells, and mesenchymal stem cells (MSCs). The term "extracellular vesicle" broadly encompasses several types of vesicles including exosomes, microvesicles, and apoptotic bodies. However, the word "exosome" specifically denotes vesicles that are formed inside multivesicular bodies (MVBs) within cells [1-3]. Exosomes carry vital information and macromolecules from their source of origin and thus have a significant role in cell-cell communication. These macromolecules consist of a variety of proteins, enzymes, transcription factors, lipids, extracellular matrix proteins, receptors, and nucleic acids, and can be found both on the inside and outside of the exosomal surface (Figure 1). Exosomes have been detected in almost all body fluids in both heathy and disease conditions, including fluids such as urine, blood, serum, breast milk, amniotic fluid, cerebrospinal fluid, malignant ascites, saliva, bile, and lymph (Figure 2) [4-12]. 


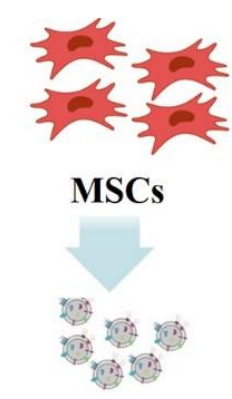

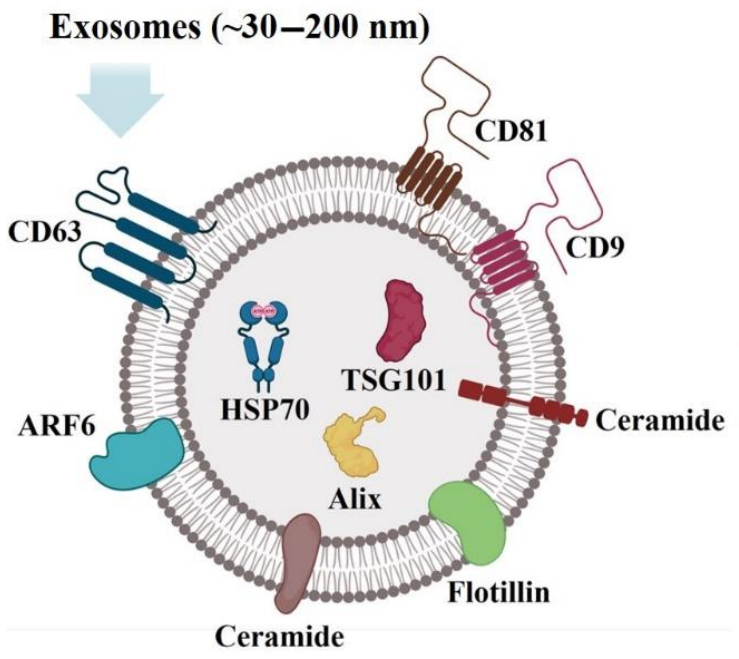

Biomarkers of exosomes

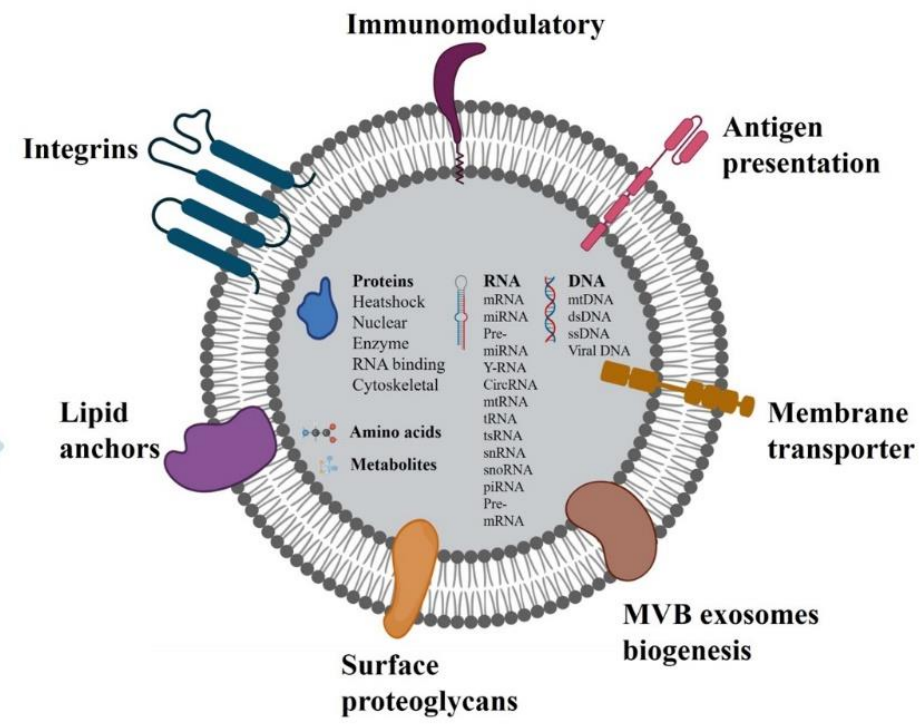

Content of exosomes

Figure 1. Typical exosomes. A powerful communication system between local and distant cells in the human body with pleiotropic functions. Exosomes are a type of extracellular vesicle secreted by cells such as MSCs that carry therapeutic payloads, including proteins, nucleic acids, lipids, enzymes, and metabolites.

Exosomes were first discovered by Pan and Johnstone while investigating the maturation mechanisms of sheep reticulocytes into erythrocytes [13-15]. The researchers discovered a type of vesicle (which they later named: "exosome") that was released from reticulocytes and contained lipids, proteins, and enzymes of reticulocyte origin [16]. Exosomes were initially assumed to be cellular debris or garbage disposal and considered signs of cell death [17-19]. Since their discovery, extensive research has been carried out to determine the biology, function, and potential clinical uses of exosomes. It is now established that exosomes are released by donor cells into the extracellular environment to perform diverse biological functions, including intracellular communication and the exchange of genetic material and proteins between a parent cell and surrounding cells (Figure 1) $[20,21]$. The clinical importance of exosomes has been established in their use as alternatives to liposome-mediated drug delivery in cancer immunotherapy. Exosomes are also a promising biological gene delivery system due to their microRNA and mRNA content [22-25]. However, there are still many aspects of exosomes that are not fully understood or characterized. For example, as many potential targets for cancer therapy are tumor-specific biomarkers, it is crucial to study the biomarkers present on the surface of exosomes in order to develop tumor-targeting therapies [26,27]. The great potential of these small wonder vesicles to aid in gene delivery, disease diagnostics, intracellular communication, drug delivery, and biomarker-driven therapies has progressively drawn the attention of researchers. 


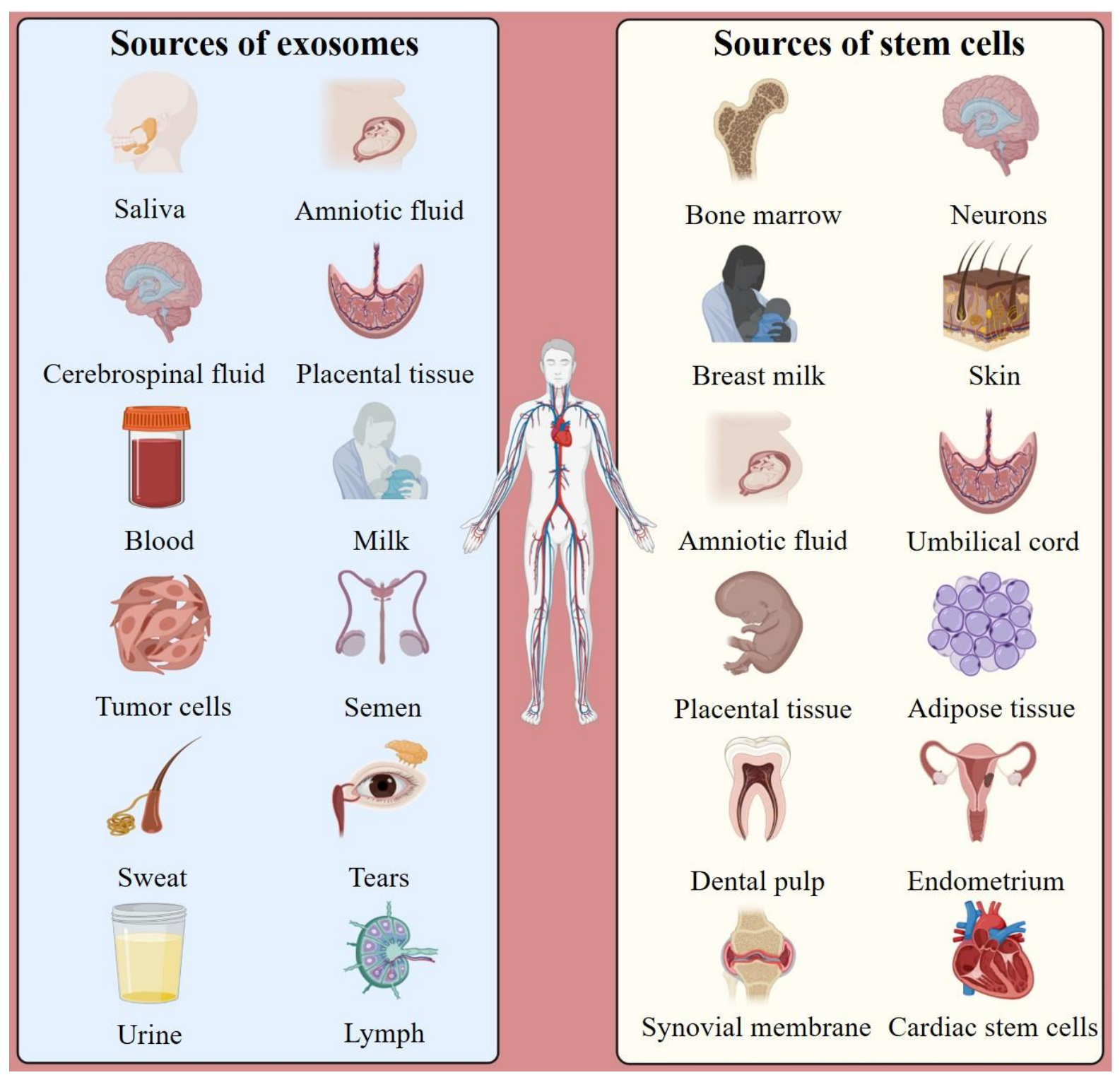

Figure 2. Sources of exosomes and stem cells. Exosomes have been detected in almost all body fluids, including, amniotic fluid, urine, cerebrospinal fluid, blood, serum, breast milk, malignant ascites, saliva, bile, etc. MSCs are non-hematopoietic, multipotent, adult stem cells which can be isolated from bone marrow, umbilical cord, placental tissue, adipose tissue, dental pulp, neurons, skin, breast milk, etc.

Stem cell therapies have increasingly gained momentum in treatment of disease; much of the research that has been done in recent years has focused on the potential significance of applying MSCs [28,29]. MSCs are non-hematopoietic, multipotent, adult stem cells which can be isolated from many biological sources including bone marrow, umbilical cord, adipose tissue, brain, spleen, kidney, and liver (Figure 2) [30-35]. MSCs can differentiate into adipocytes, chondrocytes and osteocytes, as well as endodermal (hepatocytes) and ectodermal lineages (neurocytes) [36]. In addition to their mechanical differentiation properties, MSCs also secrete exosomes and biomolecules including cytokines, chemokines, and growth factors. Though initial reports indicated that MSCs may play a critical role in tissue repair, investigations have shown poor survival and low grafting potential of MSCs in damaged tissue areas, limiting MSC effectiveness in tissue repair [37-41]. Further studies have demonstrated that beneficial effects of MSCs applications in repair are attributable to paracrine signaling, which includes secreted vesicles such as exosomes [42-46]. Interestingly, several studies indicate that exosomes secreted by MSCs can replace the MSC-based 
stem cell therapies in various injury and disease models [28,29]. For example, MSC-derived exosomes (MSC-Exos) have been shown to induce repair in mouse models of wound healing and myocardial infarction (Figure 3) [47-51]. In particular, investigations have revealed that exosomes secreted by placental umbilical cord MSCs play a significant role in wound healing and tissue regeneration [52]. Similarly, in the past few decades, studies have demonstrated that MSC-Exos can have advantageous effects in various contexts including neurological, respiratory, cartilage, kidney, cardiac, and liver diseases, bone repair, and cancer (Figure 3) [28,29,48,53-59].

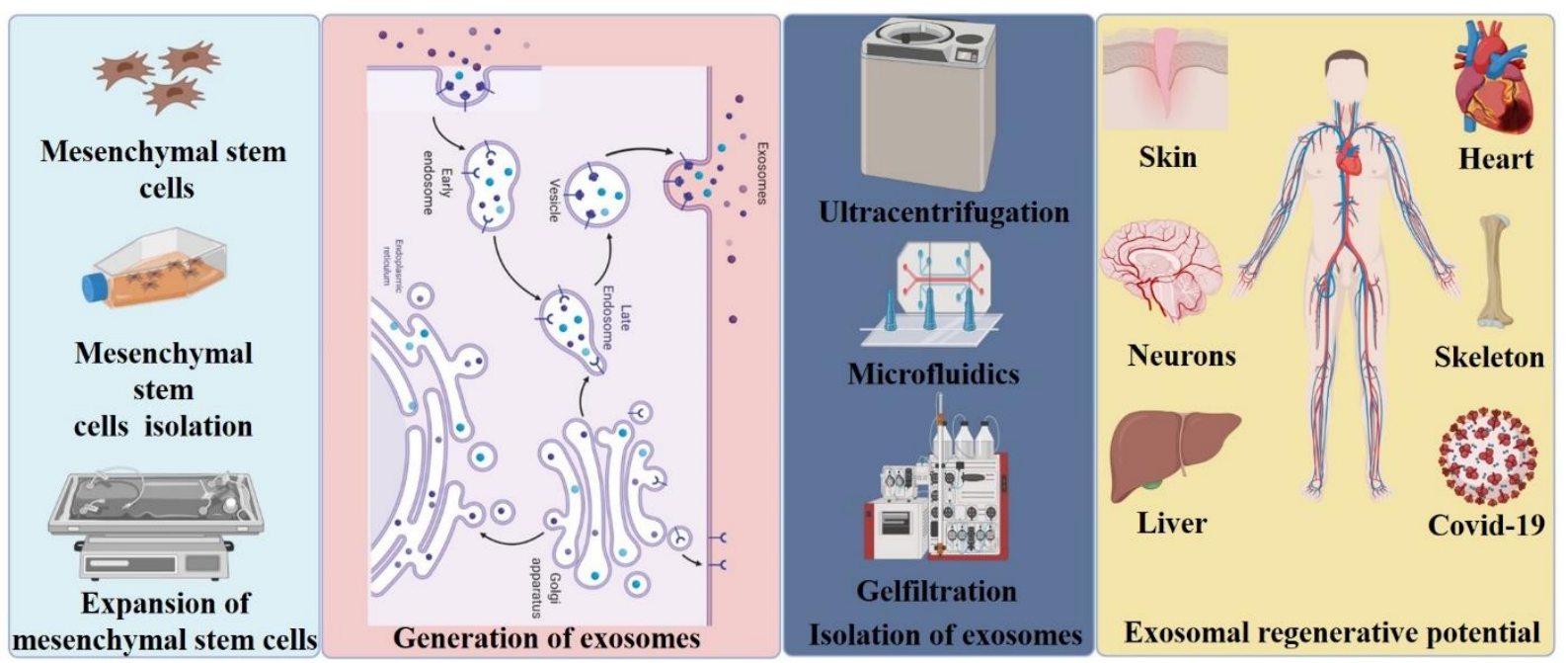

Figure 3. MSC-derived exosome methodology. Graphical representation of isolation of MSCs, exosome biogenesis, isolation of exosomes. and therapeutic applications of exosomes in regenerative medicine.

In short, MSC-Exos can serve as a smart drug delivery approach through the transportation of exogenous chemicals and biomolecules for stem cell-free regenerative medicine. MSC-Exos have many potential therapeutic advantages when compared to synthetic nanoparticles, liposomes, single molecules, and cells. This stems from their novel beneficial characteristics such as smaller size, lower complexity, lack of nuclei (thus preventing neoplastic transformation), increased stability, easier production, longer preservation, and potential for loading proteins, small molecules, or RNAs for delivery of biomolecules [60]. MSC-Exos can also be modified to display distinct antibodies or surface receptors to transfer therapeutic payloads to specific organs, tissues, and cells. Additionally, MSC-Exos host numerous types of biological molecules, enabling them to participate in various therapeutic approaches simultaneously, which cannot be accomplished with conventional small molecules. Therefore, here, we review the recent advancements in the field of molecular mechanisms of exosomes in regenerative medicine and exosome research, as well as address the potential therapeutic approaches of exosomes in tissue regeneration due to disease and injury recovery.

\section{Exosome Biogenesis, Secretion and Uptake}

The structure and composition of exosomes depends on several factors including the donor cell, microenvironment, and physiological conditions. Exosomes are formed from endosomal vesicles via the exocytosis process (Figure 4). As cargo transporters, exosomes can carry proteins, peptides, nucleic acids, and lipids. Studies investigating the protein composition of exosomes have shown that, while some proteins specifically arise from parental tissue, some were unique to exosomes [1,2,9]. Specific proteins contained within exosomes include those present in the endosome, plasma membrane, and cytoplasm, implying differential selection [20]. Additionally, several studies have shown that exosomes carry nucleic acids including different RNA types, e.g., microRNA, messenger RNA, 
and non-coding RNA [61-67]. Interestingly, the composition of proteins, peptides, and nucleic acids in exosomes are independent of donor cell types; on the other hand, the lipid composition in exosomes primarily depends on exosome-producing cells. Typically, exosomes contain plasma membrane lipids including sphingomyelin (SM), desaturated phosphatidylethanolamine, phosphatidylserine (PS), desaturated phosphatidylcholine (PC), cholesterol (CHOL), GM3, and ganglioside [68-73].

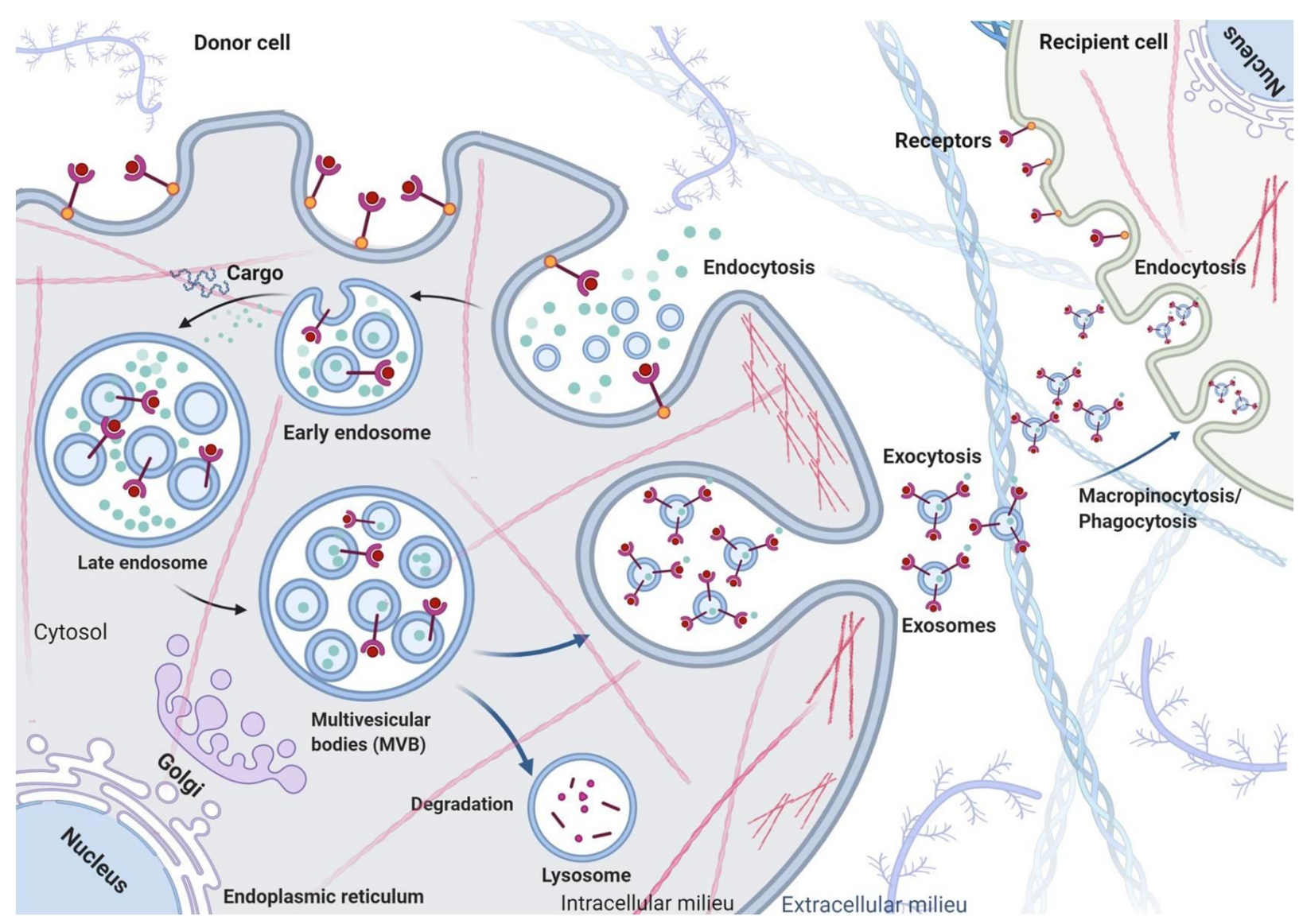

Figure 4. Exosome biogenesis, secretion and uptake. Extracellular milieu is composed of various components including proteins, lipids, small molecules, numerous metabolites, which enter the cell through the process of endocytosis. This process leads to the formation of early endosomes; cargo is wrapped into intraluminal vesicles within multivesicular bodies (MVB) upon inward budding of the membrane. Further, early endosomes are transformed into late endosomes, which later give rise to the multivesicular bodies. The modified multivesicular bodies have a cargo of extracellular milieu and cytoplasmic constitutes. Multivesicular bodies and their exosomal content can follow two primary pathways. In the first, they can be fused with autophagosomes and follow the degradation pathway through lysosomes. In the second pathway, multivesicular bodies can fuse to the plasma membrane through the microtubule and cytoskeletal network, and be released by budding from cytomembrane. Furthermore, the exosomes released through exocytosis interact with recipient cells through cell signaling molecules on their respective surfaces. Exosomes can also enter into recipient cells by employing different mechanisms such as endocytosis, macropinocytosis, phagocytosis and direct fusion of plasma membranes. Various proteins are involved in exosome biogenesis, secretion and uptake, include ESCRT, AAA ATPases, ESCRT-associated protein, SNAREs, Rabs, and other enzymes (Table 1).

The biogenesis of exosomes occurs via exocytosis: a depiction of exosome biogenesis, secretion, and uptake is detailed in Figure 4. Exosomes are generated from multivesicular endosomes (MVEs); generally, the intraluminal vesicles (ILVs) of MVEs are subjected to lysosomal degradation by hydrolases. However, escaped MVEs, such as multivesicular bodies (MVBs), can directly fuse with cellular plasma membrane and, through the process of budding, are subsequently secreted to the extracellular milieu as exosomes. There, the 
exosomes have pleiotropic functions through paracrine signaling [20]. Currently, little is known about the underlying mechanism behind the sorting of exosomes into the different populations. Studies have revealed that MVBs specifically contain various lysosomeassociated molecules such as lysosomal-associated membrane protein 1, 2, and 3 (LAMP-1, $-2,-3)$, tetraspanins, and a cluster of differentiation factors (CD-107a, CD-107b, CD-208 or CD-63) (Figure 1), whereas late endosomes possess major histocompatibility complex (MHC) class II [20,74]. Hanson and Cashikar explored the morphogenesis mechanism of MVBs and found that the endosomal sorting complex required for transport (ESCRT) plays a crucial role in driving both exosomal and ectosomal biogenesis [75]. ESCRT comprises approximately 30 different proteins that are organized into four machinery complexes, namely ESCRT-0, -I, -II, and -III in association with vacuolar protein sorting associated protein 4 (VPS4), vesicle trafficking 1, and apoptosis-linked gene 2-interacting protein $X$ (Alix) which is also called programmed cell death six interacting protein [75]. The initial ESCRT-0 complex assists in recognizing and sorting ubiquitinated intracellular cargos that are prescribed for lysosomal degradation. ESCRT-I and -II contribute to deforming the membrane into buds with sequestered vesicles, whereas ESCRT-III plays a role in vesicle scission [76]. ESCRT-independent biogenesis mechanisms are proposed to involve tetraspanins (CD63, CD9, CD37, CD82 or CD81), which have been identified as exosomal markers. These proteins are vital in extracellular vesicle biogenesis and essential for extracellular vesicle secretion and uptake by receptor cells. Hydrolysis of sphingomyelin into ceramide is also known to contribute to the biogenesis of exosomes [20,77]. As a summary, Table 1 includes the composition and functions of proteins, e.g., ESCRT, AAA ATPases, ESCRT-associated proteins, SNAREs, Rabs, and other enzymes, that are actively involved in exosome biogenesis, sorting, transport, and secretion [78-89].

Table 1. Composition and function of complexes and key enzymes related to exosome biogenesis, sorting, transport, and secretion.

\begin{tabular}{|c|c|c|c|c|}
\hline Complexes & Subunits & Localization & Function & References \\
\hline ESCRT & ESCRT-O (HRS, STAM) & MVBs & $\begin{array}{l}\text { Recognizes and binds } \\
\text { ubiquitinated proteins and sorts } \\
\text { them into spatially restricted } \\
\text { areas on the endosomal } \\
\text { membrane; HRS recognizes the } \\
\text { mono-ubiquitinated proteins } \\
\text { and recruits TSG101 }\end{array}$ & {$[78,79,88]$} \\
\hline ESCRT & $\begin{array}{l}\text { ESCRT-1 (TSG101, } \\
\text { VPS28, VPS37, MVB12); } \\
\text { ESCRT-2 (VPS36, } \\
\text { VPS22, VPS25) }\end{array}$ & MVBs & $\begin{array}{l}\text { Regulates the initial deformation } \\
\text { of membrane into buds with } \\
\text { sequestered cargo and may be } \\
\text { involved in cargo transfer }\end{array}$ & {$[78,79,88]$} \\
\hline ESCRT & ESCRT-3 (VPS2, VPS20) & ILV, MVBs & $\begin{array}{l}\text { Drives membrane invagination } \\
\text { and subsequent vesicle scission }\end{array}$ & {$[78,79,88]$} \\
\hline AAA ATPases & VPS4 & ILVs & $\begin{array}{l}\text { Interact with ESCRT-3 to cause } \\
\text { constriction and scission of ILV }\end{array}$ & [88] \\
\hline $\begin{array}{l}\text { ESCRT-associated } \\
\text { proteins }\end{array}$ & ALIX & ILVs, MVBs & $\begin{array}{l}\text { Controls exosomal cargo } \\
\text { incorporation and regulates } \\
\text { sorting of PD-L1 on to ILVs; } \\
\text { ALIX and syntenin-ALIX and } \\
\text { syntenin-ALIX complex } \\
\text { stimulate intraluminal budding }\end{array}$ & {$[82,86]$} \\
\hline Rabs & Rab5 & PM, Early endosome & $\begin{array}{l}\text { Mediates endocytosis and } \\
\text { generation and maintenance of } \\
\text { early endosomes }\end{array}$ & {$[80,87]$} \\
\hline
\end{tabular}


Table 1. Cont.

\begin{tabular}{|c|c|c|c|c|}
\hline Complexes & Subunits & Localization & Function & References \\
\hline Rabs & Rab7 & MVBs & $\begin{array}{l}\text { Mediates maturation and } \\
\text { trafficking of MVBs to lysosomes }\end{array}$ & [87] \\
\hline Rabs & Rab27a & MVBs & $\begin{array}{c}\text { Involved in the fusion of MVBs } \\
\text { to the PM }\end{array}$ & {$[83,85]$} \\
\hline Rabs & Rab27b & MVBs & $\begin{array}{l}\text { Promotes formation and stability } \\
\text { of MVB docking and facilitates } \\
\text { exosome shedding }\end{array}$ & {$[83,84]$} \\
\hline Rabs & Rab35 & MVBs & $\begin{array}{l}\text { Controls MVB transport and } \\
\text { influences the docking process }\end{array}$ & [89] \\
\hline SNAREs & t-SNARE; v-SNARE & $\begin{array}{c}\text { Widespread } \\
\text { distribution in } \\
\text { endosomal system }\end{array}$ & $\begin{array}{l}\text { Drive membrane fusion and } \\
\text { mediate fusion of MVBs with the } \\
\text { PM }\end{array}$ & {$[89,90]$} \\
\hline Enzyme & Heparanase & $\begin{array}{l}\text { PM, endosome } \\
\text { membrane }\end{array}$ & $\begin{array}{l}\text { Exogenous heparanase impacts } \\
\text { intraluminal budding and, } \\
\text { therefore, exosome biogenesis }\end{array}$ & [86] \\
\hline Enzyme & snMase2/SMPD3 & PM, endosomes & $\begin{array}{l}\text { Regulates biosynthesis of } \\
\text { ceramide and promotes budding } \\
\text { of intravesicular vesicles }\end{array}$ & {$[81,85]$} \\
\hline
\end{tabular}

Abbreviation: ESCRT, endosomal sorting complex required for transport; STAM, signaling transducing adaptor molecule; MVB, multivesicular body; VPS, vacuolar protein sorting associated protein; ILV, intraluminal vesicles; ALIX, apoptosis-linked gene 2-interacting protein X; PM, plasma membrane.

\section{Complicated Architecture of Exosomes}

All exosomes share typical characteristic compositions of donor cells, and cargo can include proteins (tetraspanins, annexins, heat shock proteins, etc.), lipids (glycosphingolipids, sphingomyelins, cholesterol), genetic materials (DNA, tRNA, mRNA, miRNA, small and long noncoding RNAs (sncRNA and lncRNA, respectively)), and small-molecule metabolites (amino acids, ATP, amides, sugars, etc.) (Tables 2-4) [67,91-98]. The main database available for protein content in exosomes is ExoCarta (http:/ / exocarta.ludwig.edu.au/ accessed on 17 April 2021); the recent version of ExoCarta includes listings from over 286 exosomal investigations annotated with International Society for Extracellular Vesicles' minimal experimental requirements for definition of exosomes: data include 41,860 proteins, 1116 lipid molecules, and more than 7540 RNAs. Other databases include Vesiclepedia (http:/ / www.microvesicles.org/ accessed on 17 April 2021), and the Urinary Exosomes Protein Database (http:/ / dir.nhlbi.nih.gov/papers/lkem/exosome/ accessed on 17 April 2021) [99-102].

Table 2. Distinct protein families identified in exosomes from different cell types.

\begin{tabular}{cccc}
\hline Protein Class & Name & Cell Type & Reference \\
\hline & & B cells & \\
& MHC class I & Dendritic cells \\
Enterocytes & Tumors \\
& & T cells & [103-107] \\
Antigen Presentation & & B cells & Dendritic cells \\
& & Enterocytes \\
& MHC class II & Mastocytes & T cells \\
& & Dendritic cells & {$[109,105,107,108]$} \\
\hline
\end{tabular}


Table 2. Cont

\begin{tabular}{|c|c|c|c|}
\hline Protein Class & Name & Cell Type & Reference \\
\hline \multirow{5}{*}{ Integrins } & $\alpha 4 \beta 1$ & Reticulocytes & [110] \\
\hline & $\alpha \mathrm{M} \beta 2$ & Dendritic cells & [111] \\
\hline & $\beta 2$ & $\mathrm{~T}$ cells & [103] \\
\hline & $\alpha \mathrm{L} \beta 2$ & Mastocytes & [112] \\
\hline & $\alpha 3$ & & \\
\hline \multirow{3}{*}{$\begin{array}{l}\text { Immunoglobulin family } \\
\text { members }\end{array}$} & ICAM1/CD54 & $\begin{array}{l}\text { B cells } \\
\text { Dendritic cells } \\
\text { Mastocytes }\end{array}$ & [112-114] \\
\hline & P-selection & Platelets & [112] \\
\hline & A33 antigen & Enterocytes & [105] \\
\hline \multirow{2}{*}{ Cell surface peptidases } & Dipeptidylpeptidase IV/CD26 & Enterocytes & [105] \\
\hline & Aminopeptidase n/CD13 & Mastocytes & [112] \\
\hline \multirow[t]{3}{*}{ Tetraspanins } & CD63 & $\begin{array}{c}\text { B cells } \\
\text { Dendritic cells } \\
\text { Enterocytes } \\
\text { Mastocytes } \\
\text { T cells } \\
\text { Platelets }\end{array}$ & {$[103,105,107,114-116]$} \\
\hline & CD37, CD53, CD81, CD82 & B cells & [114] \\
\hline & CD9 & Dendritic cells & [111] \\
\hline \multirow{3}{*}{ Heat shock proteins } & HSC70 & $\begin{array}{c}\text { Tumors } \\
\text { Reticulocytes } \\
\text { Dendritic cells }\end{array}$ & {$[16,106,111]$} \\
\hline & HSP70 & $\begin{array}{c}\text { Tumors } \\
\text { Peripheral blood mononuclear } \\
\text { cells }\end{array}$ & [117-120] \\
\hline & HSP84/90 & $\begin{array}{l}\text { Enterocytes } \\
\text { Dendritic cells }\end{array}$ & {$[105,111]$} \\
\hline \multirow{3}{*}{ Cytoskeletal proteins } & Actin & $\begin{array}{l}\text { Mastocytes } \\
\text { Dendritic cells } \\
\text { Enterocytes }\end{array}$ & \\
\hline & Actin binding protein (cofilin) & Dendritic cells & \\
\hline & Tubulin & $\begin{array}{l}\text { Dendritic cells } \\
\text { Enterocytes }\end{array}$ & \\
\hline \multirow{3}{*}{$\begin{array}{l}\text { Membrane transport and } \\
\text { fusion }\end{array}$} & Annexins I, II, IV, V, VI & Dendritic cells & [121] \\
\hline & Annexin VI & Mastocytes & [112] \\
\hline & RAB7/RAP1B/RABGDI & Dendritic cells & [121] \\
\hline \multirow{2}{*}{ Signal transduction } & Gi2 $\alpha / 14-3-3$ & Dendritic cells & [121] \\
\hline & CBL/LCK & $\mathrm{T}$ cells & [103] \\
\hline \multirow{2}{*}{ Metabolic enzymes } & Enolase 1 & Enterocytes & [105] \\
\hline & Thioredoxin peroxidase & Dendritic cells & [121] \\
\hline
\end{tabular}


Table 3. Important protein families identified within or externally located on exosomes [122-125].

\begin{tabular}{|c|c|}
\hline Protein Class & Name \\
\hline Metabolic enzymes & $\begin{array}{c}\text { Phosphoglycerate kinase } 1 \\
\text { NADP-dependent malic enzyme } \\
\text { Citrate synthase } \\
\text { Malate dehydrogenase } \\
\text { Fatty acid binding protein-3 } \\
\text { Fatty acid binding protein- } 4\end{array}$ \\
\hline Secretory/membrane proteins & $\begin{array}{c}\text { MFG-E8 } \\
\text { Adiponectin } \\
\text { Fasting-induced adipose factor } \\
\text { CD9 } \\
\text { CD63 } \\
\text { Integral membrane protein TAPA-1 } \\
\text { Clathrin heavy chain } \\
\text { MMP-2 } \\
\text { MMP-9 } \\
\text { Coagulation factor II } \\
\text { Coagulation factor V } \\
\text { Fibulin 2 } \\
\text { Annexin II }\end{array}$ \\
\hline Heat shock proteins & $\begin{array}{c}\text { Hsp1 } \\
\text { HSP60 } \\
\text { HSP70 } \\
\text { HSP75 } \\
\text { HSP84 } \\
\text { TCP-1 chaperone family } \beta \text {-subunit } \\
\text { TCP-1 chaperone family } \gamma \text {-subunit } \\
\text { TCP-1 chaperone family } \varepsilon \text {-subunit }\end{array}$ \\
\hline GPI-anchored proteins & $\begin{array}{l}\text { Gce1 } \\
\text { CD73 }\end{array}$ \\
\hline Ubiquitin/proteasome-related proteins & $\begin{array}{c}\text { 26S proteasome subunit } \alpha 1 \\
26 \mathrm{~S} \text { proteasome subunit } \beta 3 \\
\text { 26S proteasome subunit } \beta 5 \\
\text { 26S proteasome subunit Rpn13 } \\
\text { Ubiquitin-activating enzyme E1 }\end{array}$ \\
\hline Nuclear proteins & $\begin{array}{c}\text { Histone H1.1 } \\
\text { Histone H1.5 } \\
\text { Histone H1.3 } \\
\text { Histone H2A } \\
\text { Histone H2B } \\
\text { Histone H4 } \\
\text { 40S ribosomal protein SA } \\
\text { 40S ribosomal protein S8 } \\
\text { 60S ribosomal protein L7 } \\
\text { 60S ribosomal protein L18a }\end{array}$ \\
\hline Cytoskeleton & $\begin{array}{c}\text { Actr1b protein } \\
\beta \text {-Actin } \\
\text { Tubulin } \alpha 2 \\
\text { Tubulin } \beta 2 \\
\text { Tubulin } \beta 5 \\
\end{array}$ \\
\hline Membrane transport/fusion & $\begin{array}{l}\text { Annexin II } \\
\text { Annexin V }\end{array}$ \\
\hline Miscellaneous & $\begin{array}{c}\text { Galectin } 1 \\
\text { Galectin } 3 \\
\text { Translation elongation factor-1 } \\
\text { Translation elongation factor-2 } \\
\text { Translation initiation factor 4A } \\
\text { Major vault protein } \\
\text { 14-3-3 } \beta \\
\text { Dynein heavy chain } \\
\text { Albumin }\end{array}$ \\
\hline
\end{tabular}


Table 4. Lipid families identified in exosomes released from various cell types.

\begin{tabular}{|c|c|c|}
\hline Lipids & Cell Types & References \\
\hline SM, PC, PE, PS, PI, CHOL, Plip & Erythrocytes & [126] \\
\hline $\begin{array}{c}\text { SM, PC, PE, PS, PI, LPC, CHOL, Plip, HexCer, } \\
\text { LacCer }\end{array}$ & Mast cells & {$[70,126,127]$} \\
\hline SM, PC, PE, PS, PI, LPC & Dendritic cells & [126] \\
\hline SM, GM3, PCP, SPI, PE, EthLip, CholPlip, DAG & B lymphocytes & {$[70,126]$} \\
\hline SM, PC, PS, PE, CholPlip & T lymphocytes & {$[70,126]$} \\
\hline $\begin{array}{c}\text { Acylcarnitine, Cholesterol, Sphingolipids, glyserolipids, } \\
\text { glycerophospholipids }\end{array}$ & $\begin{array}{c}\text { Non-tumorigenic (RWPE1), tumorigenic } \\
\text { (NB26) and metastatic (PC-3) prostate cell } \\
\text { lines }\end{array}$ & [128] \\
\hline $\begin{array}{c}\text { CHOL, SM, PC, PS, PE, PE, ethers, DAG, PC ethers, PG, PA, PI, } \\
\text { Cer, HexCer, LacCer }\end{array}$ & PC-3 Cells & {$[70,92]$} \\
\hline $\begin{array}{c}\text { CHOL, SM, PC, PS, PE, PE, ethers, DAG, PC, ethers, PG, PA, PI, } \\
\text { Cer, HexCer, LacCer }\end{array}$ & PC -3 cells + HG & [70] \\
\hline CHOL, SM, PC, PS, PE, PI, Cer, HexCer, LacCer & Oli-neu Cells & [70] \\
\hline CHOL, SM, PC, PS, PE, PI, CerHex, Cer, LacCer & HepG2/C3a & {$[70,129]$} \\
\hline CHOL, SM, PC, PS, PE, PI, Cer, HexCer, LacCer, Gb3 & Prostasome & {$[70,130]$} \\
\hline $\begin{array}{l}\text { CHOL, SM, PC, PS, PE, PE, ethers, PC, ethers PI, Cer, HexCer, } \\
\text { LacCer, Gb3 }\end{array}$ & Urine & {$[70,131]$} \\
\hline CHOL, SM, PC, PS, PE, PE, ethers, PC, ethers & Nematodes & {$[70,132]$} \\
\hline CHOL, SM, PC, PS, PE, PI, Cer, HexCer, LacCer & Reticulocytes & {$[71,73]$} \\
\hline CHOL, SM, PC, PS, PE, PE, ethers, PC, ethersPI, Cer & Platelets & {$[71,133]$} \\
\hline CHOL, SM, PC, PS, PE, PE, ethers, DAG, PI, CerHexCer & Adipocytes & {$[71,134]$} \\
\hline
\end{tabular}

Abbreviation: EthLip, ether lipids; CHOL, cholesterol; PLIP, phospholipids; Prot, proteins; SM, sphingomyelins; PC, phosphatidylcholines; PE, phosphatidylethanolamines; PS, phosphatidylserines; PI, phosphatidylinositols; LPC, lysophosphatidylcholines; PE, Phosphatidylethanolamine; PG, Phosphatidylglycerol; PA, Phosphatidic acid; SMG, Sphingomyelin; GSLe, lycosphingolipids; CE, Cholesterol ester; LPCb, Lysophosphatidylcholine; DAG, diacylglycerol; LacCer, lactosylceramide.

\section{Proteins}

Exosomal proteins perform various functions such as targeting/adhesion, anti-apoptosis, membrane fusion, signal transduction, metabolism, and structural dynamics $[2,9]$. There are similarities in protein content between species, as the available proteomic data for exosomes isolated from mouse and human dendritic cells (DCs) suggest that about $80 \%$ of the proteins are conserved in the two species $[2,9,121]$. However, based on proteomic studies, exosomes isolated from different cell types contain specific groups of proteins depending on the secreting cell types (Table 2). Western blot and fluorescence-activated cell sorting analysis can identify known cellular proteins in exosomes prepared from different cell types $[74,107,108,135,136]$. For unknown cellular proteins, mass spectrometry associated with trypsin digestions can analyze exosomes derived from cells like mast cells, DCs, and enterocytes $[2,105,112,121,137-140]$. These methods have been used to identify cytosolic proteins present in exosomes including actin, tubulin, cytoskeletal components, and actin-binding proteins, as well as Rab and annexins, which are important in intracellular membrane fusions and transport function (Tables 2 and 3). Exosomes also contain different types of 14-3-3, heterotrimeric G proteins, and protein kinases, which are critical in signal transduction during critical physiological processes. Further, exosomes derived from human DCs and enterocytes contain various types of metabolic enzymes such as enolases, peroxidases, and lipid kinases. The two constitutive forms of heat shock proteins (i.e., HSP70 and HSP90) are found in exosomes which perform the function of antigen presentation and aid in loading antigenic peptides onto MHC class I molecules (Table 3). Notably, the MHC class I molecules are present in most isolated exosomes [141-144]. 
Exosomes also consist of proteins that are involved in specific cellular functions. For example, MHC class II molecules are present in large amounts in exosomes. Exosomes derived from DCs contain CD86, which acts as costimulatory molecule for T cells, and can contain cell-specific transmembrane proteins such as $\alpha \mathrm{M}, \beta 2$ on DCs, and T cells, $\alpha 4 \mathrm{~B} 1$. Other exosome proteins include immunoglobulin-family members, intercellular adhesion molecule 1 (ICAM1)/CD54 on B cells and cell-surface peptidases such as dipeptidylpeptidase IV/CD26 on enterocytes and aminopeptidase N/CD13 on mastocytes [145]. Additionally, exosomes harbor a vast variety of glycosylphosphatidylinositol (GPI) anchored proteins, nuclear proteins, and proteasome related proteins. Finally, the proteome of exosomes of various cell types are also divided into several signaling molecules and enzymes complexes (Tables 2 and 3) [122-125,146].

\section{Lipids}

Lipids are the least studied but most crucial components within exosomal membranes. Exosomes contain an abundance of lipids including glycosphingolipids, sphingomyelins (SM), cholesterol (CHOL), and phosphatidylserine (PS). Lipids not only play an important role in the structure of exosomal membranes, but also facilitate the formation of exosomes and their release into extracellular milieu [73,147,148]. Exosomes mainly contain monounsaturated fatty acids, polyunsaturated fatty acids, and saturated fatty acids, though the lipid composition of an exosome depends on the parent cells from which the exosome is derived [69-72]. Interestingly, exosomes can transport several bioactive lipids and lipid metabolism-related enzymes [126,149]. Fatty acids such as arachidonic acid (AA), leukotrienes prostaglandins, phosphatidic acid, docosahexaenoic acid (DHA), and lysophosphatidylcholine (LPC) have been found in MSC-Exos. The lipid metabolism enzymes of exosomes can modulate the cell homeostasis of a beneficiary [71,150].

The lipid classes found in different exosome types based on the published investigations are shown in Table 4. Methods such as thin-layer chromatography, gas-liquid chromatography, and mass spectrometry have been used to identify the lipids in exosomes [71]. Studies have shown that the content of CHOL, SM, glycosphingolipids, and PS is 2-3 times higher in exosomes compared to their parent cell. In addition to this, the majority of exosomes show lower content of PC and phosphatidylinositol (PI) than in parent cells. Additionally, lipid content can significantly vary by cell type. The lipid composition of exosomes isolated from hepatocyte cells (HepG2/C3a Oli-neu cells), prostate cancer cells (PC-3 cells), and PC-3 cells+ hexadecylglycerol (HG: a precursor of ether phospholipids) exhibit some similarities [66]. Furthermore, the exosome preparation from Oli-neu cells has lower enrichment of SM and higher enrichment of CHOL, as compared to exosomes isolated from PC-3 cells [66]. Reticulocyte-derived exosomes present high levels of CHOL as compared to other cells [56], while the enrichment of exosomes from adipocytes was found to contain a higher level of SM and lower level of PS than other various preparations in Table 4 [134].

Though lipidomic studies conducted on exosomes isolated from different cell types have been published, results are typically given only in the form of the number of different lipid classes. For example, the lipidomic study of exosomes isolated from colorectal cancer cells (LIM1215) identified a total of 500 lipid species [151], whereas Brzozowski et al. reported total of 187 lipid species identified in exosomes enriched from prostate cancer cell lines, i.e., PC-3, RWPE1, and NB26 [71,72,128]. Further studies have shown that exosomes secreted from epithelial cells (RWPE1) contain high amounts of fatty acids, prenol, and glycerolipids lipids. Exosomes from prostate cancer cell lines (PC-3 and NB26) show an abundant amount of sterol lipids, glycerophospholipids, and sphingolipids. In a lipidomic analysis of exosomes isolated from U87 (glioblastoma cells), Huh7 (hepatocellular carcinoma cells), and human bone marrow derived MSCs, Haraszti et al. showed that the lipid composition of MSCs and Huh7 exosomes were similar to each other but distinct from the U87 exosomes [152]. 


\section{RNAs}

Another important cargo of exosomes is RNAs, leading to the emergence of exosomes as a mediator of intracellular communication and a component of various signaling pathways [153-155]. MSC-Exos include RNA, which was found to be enclosed within cholesterol-rich phospholipid. This was demonstrated by the RNA cargo's vulnerability to RNase degradation only in the presence of sodium dodecyl sulfate (SDS)-based lysis buffer, a chelator of cholesterol, cyclodextrin, and phospholipase A2 [154,155].

Ethidium bromide staining, a technique routinely used for the detection of RNA, of MSC exosomal RNAs found that they consist of mainly short RNAs ( $<300 \mathrm{nt})$, whereas $28 \mathrm{~S}$ and 18S RNAs were not visible $[67,154,156,157]$. A primary exosomal mechanism of action is thought to be post-transcriptional gene regulation via microRNA content (miRNAs, miRs), which are small, endogenous RNA molecules around 22 nucleotides in length. miRNAs have been shown to play pivotal roles in health and disease, including cancer, cardiovascular diseases, and wound healing [158]. Microarray hybridization of MSC-derived exosomal RNA against probes for 151 miRNAs revealed the existence of 60 miRNAs and ribosomal RNA degradative products $[154,155]$. Comparative analysis of the composition of MSC exosomal miRNAs with their cellular miRNA revealed that 106 miRNAs from the MSCs were not secreted in the MSC exosomes. These results suggested that MSCs secrete a select population of miRNA through a regulated process. Furthermore, an ample amount of passenger miRNA has been found in MSC-Exos [159].

There have been several studies conducted on exosomal miRNAs involved in intracellular communications and disease $[61,62,64-66]$. The plasma-derived exosomal miR-92a showed an anti-apoptotic effect on fibroblast-like synoviocytes, which ultimately leads into the destruction of bone in rheumatoid arthritis patients [66]. Researchers have found that MSC-derived exosomal miRNAs can both promote [160] and reduce tumor growth [161]. For example, Lee et al. found that miR-16, a microRNA known to target vascular endothelial growth factor (VEGF), was abundantly present in MSC exosomes, leading to an antiangiogenic effect on tumor cells [161]. MSC-derived exosomal miRNAs also play an essential role in cardiovascular protection and repair by regeneration, as well as inhibition of cardiac apoptosis and fibrosis [162]. Shao et al. discovered that MSC-Exos enclosed a higher amount of cardioprotective miRNA such as miR-29 and miR-24, and lower amount of cardiac-offensive miR-21 and miR-15 as compared to MSCs [163]. Further, it was found that human amniotic epithelial cell-derived exosomal miRNAs play a crucial role in wound healing by promoting cell migration and proliferation of fibroblasts [164]. Human amnion MSC-derived exosomal miRNA, miR-135a, promotes wound healing and fibroblast migration by downregulating large tumor suppressor kinase 2 expression [165]. Wu el al. further found that MSC-derived exosomal miR-100 provides protection to the articular cartilage and helps in regulation of cartilage homeostasis in the OA mice model via inhibition of mTOR-autophagy pathway [149]. Further, it has been identified that plasma-derived exosomal miRNAs are involved in 'extracellular matrix-receptor interaction' and contribute to Hirschsprung's disease through interfering in cell junctions [166]. Human adipose stem cell-derived exosomes loaded with miR-21 mimics play a critical role in cell proliferation and migration of keratinocytes, and treatment of diabetic chronic wounds with miR-21 mimics results in accelerated healing by collagen remodeling, increasing re-epithelization, vessel maturation, and angiogenesis in vivo [167]. Further descriptions of the role of exosomal miRNA are discussed in later sections.

\section{Emerging Technologies for Exosome Isolation}

The majority of the cells in the body secrete exosomes in the extracellular milieu; however, exosomes are also found with other body fluids (Figure 2). Since their discovery, several methods have been developed to isolate the exosomes from body fluids. In the past decades, there have been many advances in exosome detection and separation techniques, resulting in higher recovery, purity, sensitivity, and specificity of isolated exosomes 
(Table 5). Still, due to overlapping size range, small sizes, and similar morphologies to other extracellular vesicles challenges persist in isolation methods.

Table 5. Characteristics of exosome isolation methods $[3,5,168,169]$.

\begin{tabular}{|c|c|c|c|c|c|}
\hline & $\begin{array}{l}\text { Isolation } \\
\text { Technique }\end{array}$ & Equipment & Isolation Principle & Advantages & Disadvantages \\
\hline \multirow{4}{*}{$\begin{array}{l}\text { Traditional } \\
\text { methods }\end{array}$} & $\begin{array}{c}\text { Ultra- } \\
\text { centrifugation }\end{array}$ & Ultra-centrifuge & Physical method & $\begin{array}{c}\text { High sample capacity; } \\
\text { Protein and RNA } \\
\text { components are not } \\
\text { affected; Facilitated later } \\
\text { research }\end{array}$ & $\begin{array}{c}\text { Time-consuming; } \\
\text { Instrument-dependent; } \\
\text { Low purity }\end{array}$ \\
\hline & Density gradient & Ultra-centrifuge & Physical method & $\begin{array}{l}\text { High separation } \\
\text { efficiency; High purity; } \\
\text { Exosomes will not be } \\
\text { crushed or deformed }\end{array}$ & $\begin{array}{l}\text { Extended run time; } \\
\text { Equipment } \\
\text { dependence; } \\
\text { Low yield; Complex } \\
\text { process }\end{array}$ \\
\hline & $\begin{array}{l}\text { Immuno- } \\
\text { magnetic } \\
\text { beads }\end{array}$ & $\begin{array}{l}\text { Magnetic bead, } \\
\text { antibody }\end{array}$ & Chemical method & $\begin{array}{c}\text { Time efficient; Maintain } \\
\text { integrity; } \\
\text { Convenient operation; } \\
\text { Not affected by exosome } \\
\text { size; } \\
\text { No need for expensive } \\
\text { instruments }\end{array}$ & $\begin{array}{l}\text { High reagent cost; Low } \\
\text { capacity; } \\
\text { Low yields }\end{array}$ \\
\hline & Precipitation & Ultra-centrifuge & $\begin{array}{l}\text { Physical/ } \\
\text { Chemical } \\
\text { method }\end{array}$ & $\begin{array}{c}\text { High yield; Easy; } \\
\text { Concentrates diluted } \\
\text { samples }\end{array}$ & $\begin{array}{l}\text { Post-clean up is } \\
\text { needed for } \\
\text { downstream } \\
\text { applications }\end{array}$ \\
\hline \multirow{8}{*}{$\begin{array}{l}\text { Emerging } \\
\text { methods }\end{array}$} & ExoQuick & ExoQuick kit & $\begin{array}{l}\text { Physical/ } \\
\text { Chemical } \\
\text { method }\end{array}$ & $\begin{array}{l}\text { Simple steps, Quick } \\
\text { operation; Size } \\
\text { uniformity; Suitable for } \\
\text { small } \\
\text { samples, such as serum }\end{array}$ & $\begin{array}{l}\text { Impurity; Affected by } \\
\text { exosome } \\
\text { diameter; Expensive } \\
\text { reagents; Low } \\
\text { production }\end{array}$ \\
\hline & $\begin{array}{l}\text { Size Exclusion } \\
\text { Chromatogra- } \\
\text { phy }\end{array}$ & Gel filtration column & $\begin{array}{l}\text { Physical/ } \\
\text { Chemical } \\
\text { method }\end{array}$ & $\begin{array}{l}\text { High purity; Uniform in } \\
\text { size }\end{array}$ & $\begin{array}{l}\text { Low extraction volume; } \\
\text { Extensive } \\
\text { laboratory equipment } \\
\text { requirements }\end{array}$ \\
\hline & $\begin{array}{c}\text { Stirred } \\
\text { ultrafiltration }\end{array}$ & $\begin{array}{l}\text { Ultra-filtration } \\
\text { membrane, Nitrogen } \\
\text { gas }\end{array}$ & Physical method & $\begin{array}{l}\text { Does not rely on } \\
\text { equipment; Less time } \\
\text { consuming than other } \\
\text { methods; Reduces the } \\
\text { destruction of exosomes } \\
\text { during the process }\end{array}$ & $\begin{array}{c}\text { Moderate purity of isolated } \\
\text { exosomes; Loss of } \\
\text { exosomes during the } \\
\text { process }\end{array}$ \\
\hline & Filtration Device & $\begin{array}{l}\text { Microfluidic devices } \\
\text { (e.g., nano traps) }\end{array}$ & $\begin{array}{l}\text { Physical/ } \\
\text { Chemical } \\
\text { method }\end{array}$ & $\begin{array}{l}\text { Fast, Low cost; Easy } \\
\text { automation and } \\
\text { integration; High } \\
\text { portability }\end{array}$ & $\begin{array}{l}\text { Lack of standardization and } \\
\text { large-scale tests on clinical } \\
\text { samples, Lack of } \\
\text { method validation; Low } \\
\text { sample capacity }\end{array}$ \\
\hline & nPES & $\begin{array}{c}\text { GNPs, } \\
\text { Antibodies }\end{array}$ & Chemical method & $\begin{array}{c}\text { Fast; Efficient; High } \\
\text { purity; } \\
\text { Quantitative analysis }\end{array}$ & $\begin{array}{l}\text { High reagent cost; Complex } \\
\text { statistical tools; Low } \\
\text { capacity }\end{array}$ \\
\hline & $\begin{array}{l}\text { Membrane } \\
\text { modification }\end{array}$ & $\begin{array}{l}\text { Magnetic field, } \\
\text { Magnetic } \\
\text { nanoparticles }\end{array}$ & $\begin{array}{l}\text { Physical/ } \\
\text { Chemical } \\
\text { method }\end{array}$ & $\begin{array}{l}\text { Needs no antibodies; } \\
\text { Save time; preserve the } \\
\text { original structure of } \\
\text { theexosomes; Drug } \\
\text { carriers }\end{array}$ & $\begin{array}{l}\text { Complicated operation; } \\
\text { Impurity }\end{array}$ \\
\hline & ExoTIC & $\begin{array}{l}\text { ExoTIC, Syringe, } \\
\text { Pump }\end{array}$ & $\begin{array}{l}\text { Physical/ } \\
\text { Chemicalmethod }\end{array}$ & $\begin{array}{l}\text { Simple operation; } \\
\text { Exosomes in a } \\
\text { specific range; High } \\
\text { purity }\end{array}$ & $\begin{array}{l}\text { Special equipment } \\
\text { requirements; } \\
\text { Lack of tests on clinical } \\
\text { samples }\end{array}$ \\
\hline & $\begin{array}{l}\text { Flow field-flow } \\
\text { fractionation }\end{array}$ & $\begin{array}{l}\text { Flow field-flow } \\
\text { fractionation } \\
\text { instrument }\end{array}$ & Physical method & $\begin{array}{l}\text { Label free isolation; Large } \\
\text { scale production }\end{array}$ & $\begin{array}{l}\text { Special instrument } \\
\text { requirement; Costly }\end{array}$ \\
\hline
\end{tabular}


The most common and traditional method of exosome isolation is ultracentrifugation/differential ultracentrifugation, which separates exosomes based on size and density $[170,171]$. This technique is comparatively cost-effective and secure, though time consuming. It is generally used for the isolation of exosomes from large volumes of biological cultures. The main disadvantage of this method is a lack of specificity, in that the separated exosomes could contain other extracellular vesicles of similar sizes. To overcome this problem, it is recommended to use iodixanol or sucrose cushions in addition to differential ultracentrifugation [172-174].

Ultrafiltration is another conventional method used for the isolation of exosomes. In this method, exosomes can be isolated based on their molecular weight or size. For example, exosomes can be separated using defined molecular weight cut-off membrane filters. The filtration method is much faster than differential ultracentrifugation and does not require any kind of unique instrument [168,171,175-177]. However, a major drawback is a lack of purity in the isolated fraction. Similar to ultracentrifugation, it is hard to omit compounds of other molecules with similar sizes to exosomes [178,179].

In addition to ultrafiltration, size exclusion chromatography (SEC) also separates exosomes on the basis of size or molecular weight $[180,181]$. SEC isolates exosomes with high purity and high yield, and acts as an essential tool in the process of exosome purification. In SEC, a column made with a solid-phase matrix of beads, with pores of different sizes, is used to separate macromolecules and other particulate matter [47,182]. SEC can be used in combination with ultracentrifugation or other techniques for higher yield of exosomes [183,184].

An immunoaffinity chromatography method can be used to enhance the purity of separated exosomes. Exosomal membrane proteins and receptor molecules are used to develop this highly specific method. In this technique, the exosomes can be captured on the column by immunoaffinitive proteins and their specific antibodies [185-187]. The immunoaffinity chromatography technique is appropriate for smaller-scale production of exosomes from fewer sample volumes. A microplate-based enzyme-linked immunosorbent assay (ELISA) is the best example of immunoaffinity-based chromatography approach used for quantifying the captured exosomes from biological samples such as a serum, plasma, and urine [188].

Exosome purification can also be carried out by precipitation $[189,190]$. Precipitationbased exosome isolation is used to concentrate the exosomes from biological fluids. Exosomes can be precipitated from cell culture media by altering their dispersibility and solubility. This can be achieved by commercially available precipitation reagents such as polyethylene glycol (PEG) [177,191]. Currently, numerous precipitation-based exosome isolation kits are available in the market. These are compatible with biological fluids such as urine, plasma, serum, cerebrospinal fluid, and cell culture medium [192,193].

Recently, microfluidic-based methods were developed for the rapid and efficient isolation of exosomes from biological samples. The main advantages of these techniques are remarkable reductions in reagent consumption, sample volume, analysis cost, and isolation time [194-196]. As scalability is enhanced through technique modification and available technologies, the needs of health care applications such as reproducibility, reliability, low cost, and speed can eventually be fulfilled. A full summary of advantages and disadvantages of the exosome isolation methods is given in Table 5.

\section{Applications of Exosomes in Injury and Disease}

Exosomes, and specifically exosomes derived from mesenchymal stem cells, have been found to have enormous benefits in a variety of diseases and injuries through the proteins and RNAs that they contain. Additionally, because exosomes are representations of their parent cells, as the cellular environment changes, so exosomes change. As such, the number and content of exosomes can be used as a biomarker for changing conditions in disease. In the following sections we summarize recent findings in problems such as wound healing, neurological damage, and hepatic diseases. 


\section{Wound Healing}

Skin damage can commonly arise due to factors such as the sun, parasites, or a fall, often leading to open abrasions with potential for infection. Injuries to the skin are healed in an intricate process that takes place in four overlapping stages: (1) hemostasis, (2) inflammation, (3) proliferation; and (4) maturation/remodeling (Figure 5) [197-199]. In the first stage, hemostasis, platelets form a blood clot to prevent blood loss. Simultaneously, the platelets secrete hormones, cytokines, and chemokines, including tumor growth factor- $\beta$ (TGF- $\beta$ ), epidermal growth factor (EGF), platelet-derived growth factor (PDGF), and fibroblast growth factor (FGF), to attract inflammatory cells (growth factors important in wound healing are summarized in Table 6) [9,40,200-204]. Inflammation, the second step of wound healing, begins within $24 \mathrm{~h}$ of injury as neutrophils infiltrate the wound and secrete products, such as toll-like receptors (TLRs) and nuclear factor K-lightchain-enhancer of activated B cells (NF-kB), to attract and activate pro-inflammatory (M1) macrophages $[9,40,201,202,204]$. M1 macrophages phagocytose pathogens, produce an oxidative burst, and remove apoptotic cells before products including signal transducer and activator of transcription 3 (STAT-3) promote the polarization of M1 macrophages into anti-inflammatory M2 macrophages, thus stimulating inflammatory resolution [205-208]. Proliferation then begins as keratinocytes and fibroblasts proliferate at the edge of the wound. Increased levels of VEGF and FGF stimulate angiogenesis, the process by which new blood vessels are formed to transport necessary nutrients, oxygen, and growth factors to the damaged tissues. Fibroblasts secrete immature type III collagen to form a new extracellular matrix (ECM), and then differentiate into myofibroblasts. These cells have contractile abilities, pulling together the edges of the wound [197,198,203,206,209]. Finally, during the maturation phase, the former ECM gets degraded by a variety of enzymes, including matrix metalloproteinases and plasminogen activators, as the type III collagen is substituted by mature type I collagen. The remodeling of the scar is a longer process than other stages of wound healing: over months or years, the scar tissue reaches its final appearance $[198,209]$. The proper sequence, timing, and regulation of these stages are critical during wound healing; any delinquency in this progression can result in the formation of chronic ulcers or hypertrophic scarring $[197,199,210]$. The major risk factors in this are underlying conditions such as aging, diabetes, and recalcitrant infections. Intemperate fibroblast activity results in hypertrophic scarring and may degenerate into keloids [210-212].
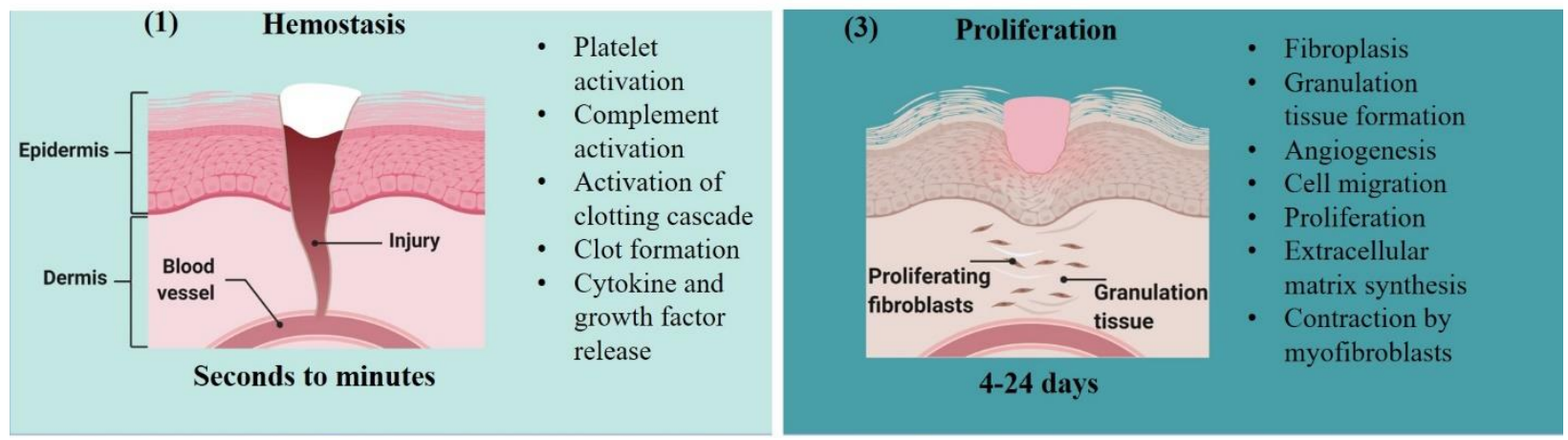

Figure 5. Cont. 

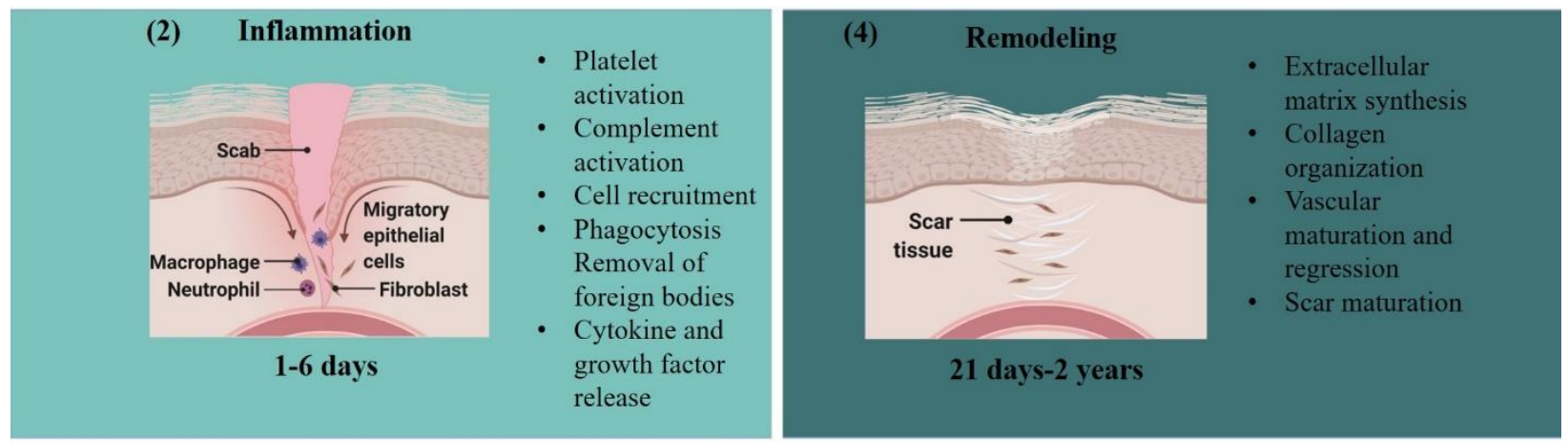

Figure 5. Phases of wound healing. The main events implicated during wound healing are hemostasis, inflammation, proliferation, and remodeling. (1) Hemostasis is the process of blood clotting and is the shortest phase in wound healing, lasting for only a few minutes. (2) The inflammatory phase comprises of blood coagulation, phagocytosis, removal of foreign bodies, and recruitment of growth factors and anti-inflammatory cells at the site of injury. (3) The proliferation phase encompasses fibroplasia, angiogenesis and cell migration, cell recruitment, re-epithelialization, and wound contraction. (4) Finally, in the remodeling phase, type I collagen replaces type III collagen in the wound site. Eventually, scar formation occurs through apoptosis.

Table 6. Summary of major growth factors families and their applications in injury healing.

\begin{tabular}{|c|c|c|c|}
\hline Growth Factor & Source & Molecular Function & References \\
\hline VEGF & $\begin{array}{c}\text { Keratinocytes, } \\
\text { Fibroblasts, } \\
\text { Macrophages, } \\
\text { Endothelial cells } \\
\text { Smooth muscle cells }\end{array}$ & $\begin{array}{l}\text { Inflammation, } \\
\text { Angiogenesis }\end{array}$ & {$[200,213-218]$} \\
\hline CX3CL1 & $\begin{array}{c}\text { Macrophages, } \\
\text { Endothelial cells }\end{array}$ & $\begin{array}{c}\text { Inflammation, } \\
\text { Angiogenesis, } \\
\text { Collagen deposition }\end{array}$ & {$[219,220]$} \\
\hline TGF- $\beta$ & $\begin{array}{l}\text { Fibroblasts, } \\
\text { Keratinocytes, } \\
\text { Macrophages, } \\
\text { Platelets }\end{array}$ & $\begin{array}{c}\text { Inflammation, Angiogenesis, } \\
\text { Granulation tissue } \\
\text { formation, Collagen } \\
\text { synthesis, Tissue } \\
\text { remodeling, Leukocyte } \\
\text { chemotactic function }\end{array}$ & {$[200,217,221-228]$} \\
\hline IL-6 & $\begin{array}{l}\text { Fibroblasts, } \\
\text { Endothelial cells, } \\
\text { Macrophages, } \\
\text { Keratinocytes }\end{array}$ & $\begin{array}{l}\text { Inflammation, Angiogenesis, } \\
\text { Re-epithelialization, Collagen } \\
\text { deposition, Tissueremodeling }\end{array}$ & {$[217,229-231]$} \\
\hline IL-1 & $\begin{array}{l}\text { Macrophages, } \\
\text { Leukocytes, } \\
\text { Keratinocytes, } \\
\text { Fibroblasts }\end{array}$ & $\begin{array}{c}\text { Inflammation, Angiogenesis, } \\
\text { Re-epithelialization, Tissue } \\
\text { remodeling }\end{array}$ & {$[217,232-235]$} \\
\hline PDGF & Platelets & $\begin{array}{c}\text { Inflammation, } \\
\text { Re-epithelialization, Collagen } \\
\text { deposition, Tissue } \\
\text { remodeling }\end{array}$ & {$[212,236]$} \\
\hline IL-27 & Macrophages & $\begin{array}{c}\text { Suppression of } \\
\text { inflammation, Collagen } \\
\text { synthesis }\end{array}$ & {$[237,238]$} \\
\hline
\end{tabular}


Table 6. Cont

\begin{tabular}{|c|c|c|c|}
\hline Growth Factor & Source & Molecular Function & References \\
\hline HGF & Fibroblasts & $\begin{array}{c}\text { Suppression of } \\
\text { inflammation, Granulationtis } \\
\text { sue formation, } \\
\text { Angiogenesis, } \\
\text { Re-epithelialization }\end{array}$ & {$[215,217,239]$} \\
\hline Activin & $\begin{array}{l}\text { Keratinocytes, } \\
\text { Fibroblasts }\end{array}$ & $\begin{array}{c}\text { Granulation tissue } \\
\text { formation, Keratinocyte } \\
\text { Differentiation, } \\
\text { Re-epithelialization, }\end{array}$ & [240-243] \\
\hline FGF-2 & $\begin{array}{l}\text { Keratinocytes, } \\
\text { Fibroblasts, } \\
\text { Endothelial cells }\end{array}$ & $\begin{array}{l}\text { Angiogenesis, Granulation } \\
\text { tissue formation }\end{array}$ & {$[217,244-248]$} \\
\hline Angiopoietin-1/-2 & Fibroblasts & Angiogenesis & {$[216,249]$} \\
\hline EGF, HB-EGF, TGF- $\alpha$ & Keratinocytes, Macrophages & Re-epithelialization & {$[217,250-254]$} \\
\hline FGF-7, FGF-10 & $\begin{array}{l}\text { Fibroblasts, } \\
\text { Keratinocytes }\end{array}$ & $\begin{array}{l}\text { Re-epithelialization, } \\
\text { Detoxification of ROS }\end{array}$ & {$[200,217,255-257]$} \\
\hline CXCL10, CXCL11 & $\begin{array}{l}\text { Keratinocytes, } \\
\text { Endothelial cells }\end{array}$ & $\begin{array}{l}\text { Re-epithelialization, Tissue } \\
\text { remodeling }\end{array}$ & {$[258-260]$} \\
\hline IL-4 & Leukocytes & Collagen synthesis & {$[217,226]$} \\
\hline GM-CSF & $\begin{array}{c}\text { Macrophages, T cells, Mast } \\
\text { cells, Natural killer cells, } \\
\text { Fibroblast, Endothelial cells }\end{array}$ & $\begin{array}{l}\text { Recruit Langerhans cells, Stimulate } \\
\text { proliferation and differentiation }\end{array}$ & {$[239,261]$} \\
\hline TNF- $\alpha$ & $\begin{array}{l}\text { Neutrophils } \\
\text { Macrophages }\end{array}$ & $\begin{array}{c}\text { Inflammation } \\
\text { Re-epithelialization }\end{array}$ & [262] \\
\hline
\end{tabular}

Abbreviation: CXCL10/11, cysteine-X amino acid-cysteine; EGF, epidermal growth factor; FGF, fibroblast growth factor; HB-EGF, heparin binding EGF; HGF, hepatocyte growth factor; IL, interleukin; PDGF, platelet-derived growth factor; TGF, transforming growth factor; VCAM-1, vascular cell adhesion molecule-1; VEGF, vascular endothelial growth factor.

One of the promising approaches for this is an exploitation of cellular therapies using MSCs and the possible role of MSC-Exos in wound healing and regeneration [39]. Though studies using MSCs have revealed that both autologous and allogenous MSCs give promising results [263], several studies have demonstrated that the effectiveness and the regenerative capacity of the conditioned media from MSCs is similar or greater than MSCs when applied to chronic wounds [37,39-41,48,264]. As such, it has been found that the MSC-derived secretome, in the form of exosomes, carries soluble factors and metabolites that play an important part during wound healing [40,41,265]. Recent research has highlighted the potential of MSC-Exos, and in particular the growth factor and microRNA content of exosomes, as a therapeutic treatment of chronic skin ulcers and hypertrophic scarring, as well as the possible role of exosomes in the modulation of different stages of wound healing (see Table 7 for an expansive list of microRNAs in wound healing) $[48,198,200,217,266,267]$. Exosomes can target several pathways including phosphoinositide 3-kinase (PI3K)/AKT, ERK, and STAT-3 which are vital in facilitating and accelerating wound healing through downstream targets such as hepatocyte growth factor (HGF), insulin-like growth factor-1, nerve growth factor (NGF), and stromal cell-derived factor $[48,50,198,268-273]$. Further, a study by Shabbir and team demonstrated a trending increase in VEGF induced by MSC-Exo administration [48]. In addition to activation of growth factors through downstream processes, growth factors such as VEGF, HGF, and PDGF have been found in exosomes isolated from MSCs of different sources [274,275]. TGF- $\beta$ has been found in low levels in umbilical cord MSC-Exos [274,276], and when exosomes are further loaded with TGF- $\beta$ cargo, can stimulate vascularization and matrix remodeling [277]. Exosomes, by proxy of their effect on and containment of growth factor, 
possess cellular proliferation and differentiation modulating properties along with high immunomodulating, immunosuppressing, and angiogenic activities, which have been demonstrated both in cell culture and animal models [50,266,269,278].

Table 7. List of miRNAs involved in the various stages of wound healing. Highly expressed microRNA are bolded [158,160,279-284].

\begin{tabular}{|c|c|c|c|c|c|c|}
\hline \multirow{2}{*}{$\begin{array}{l}\text { Inflammatory } \\
\text { Phase }\end{array}$} & \multicolumn{3}{|c|}{ Proliferation Phase } & \multirow{2}{*}{$\begin{array}{l}\text { Remodeling } \\
\text { Phase }\end{array}$} & \multirow[t]{2}{*}{ Migration } & \multirow[t]{2}{*}{ Invasion } \\
\hline & Re-Epithelialization & Angio-Genesis & $\begin{array}{c}\text { Granulation Tissue } \\
\text { Formation }\end{array}$ & & & \\
\hline miR-17-5p & $\operatorname{miR}-21$ & miR-1 & miR-15a & miR-29a & miR-196a & miR-141 \\
\hline $\operatorname{miR}-18 a$ & miR-31 & $\operatorname{miR}-21$ & miR-15b & $\operatorname{miR}-29 b$ & & $\mathrm{miR}-200 \mathrm{~b}$ \\
\hline miR-34a & miR-203 & $\operatorname{miR}-23 a$ & miR-16 & $\mathrm{miR}-29 \mathrm{c}$ & & miR-200c \\
\hline miR-106b & miR-204 & miR-29b & miR-17 & miR-192 & & \\
\hline miR-181a & miR-205 & miR-126 & miR-17-92 & & & \\
\hline $\operatorname{miR}-181 b$ & $\operatorname{miR}-210$ & miR-133a & miR-20a & & & \\
\hline miR-193b & & miR-133b & miR-20b & & & \\
\hline miR-210 & & miR-146a & miR-21 & & & \\
\hline miR-221 & & $\operatorname{miR}-210$ & $\operatorname{miR}-29$ & & & \\
\hline \multirow[t]{19}{*}{$\operatorname{miR}-222$} & & miR-218 & miR-92a & & & \\
\hline & & miR-377 & miR-98 & & & \\
\hline & & miR-939 & miR-101 & & & \\
\hline & & miR-4530 & miR-126 & & & \\
\hline & & & miR-130a & & & \\
\hline & & & miR-141 & & & \\
\hline & & & miR-184 & & & \\
\hline & & & miR-185 & & & \\
\hline & & & miR-200b & & & \\
\hline & & & miR-203 & & & \\
\hline & & & miR-205 & & & \\
\hline & & & miR-206 & & & \\
\hline & & & miR-210 & & & \\
\hline & & & miR-221 & & & \\
\hline & & & miR-222 & & & \\
\hline & & & miR-296 & & & \\
\hline & & & miR-320a & & & \\
\hline & & & miR-320b & & & \\
\hline & & & miR-378a & & & \\
\hline
\end{tabular}

Exosomes have been identified as an important regulator of inflammation. Importantly, exosomes are even beneficial in instances of chronic inflammation, such as found in diabetic patients, where higher levels of glucose thwart the proper macrophage polarization (M1 $\rightarrow$ M2), making these patients prone to chronic skin wounds [40,201-205]. MSC-Exos can promote macrophage polarization and attenuate cytokine secretion to resolve the inflammatory stage $[49,201,202]$. These effects can be explained in part through microRNA, as microRNAs such as miR-132 are highly upregulated during inflammation and can induce 
M2 polarization through regulation of TLRs [285-287]. Studies have found that miR-132 located within MSC-Exos can elevate IL-10 expression and decrease levels of NF-кB, IL-6 and IL-1 $\beta$ in favor of inflammation resolution [288-290]. Broadly, exosomes have shown significant beneficial effects on proliferation, collagen deposition, and angiogenesis, even in states of chronic wounds and comorbidities such as diabetes [272,273,291]. Several microRNAs participate in this step including miR-132, miR-126, and miR-21. miR-132 plays a role in proliferation, as it can increase the activity of the STAT-3 and ERK pathways, thereby promoting keratinocyte growth. Exosomes loaded with miR-132 improved angiogenesis by increasing the tube formation of endothelial cells $[211,289]$. In a hypoxia-like environment, exosomes have been found to be abundant with miR-126, which aids in angiogenesis through downstream activation of PI3K/AKT signaling [292,293]. Though many miRNAs can be found in exosomes, some are highly expressed, including miR-21 [280]. This important microRNA has been shown to be impactful in several diseases and injuries. miR-21 promotes migration of keratinocytes and fibroblasts, stimulating re-epithelialization, and promotes collagen synthesis [280,285,294-296]. Further, miR-21 can resolve inflammation, as miR-21 is increased in macrophages after they envelop apoptotic neutrophils, a key process in the transition from inflammation into proliferation stages $[39,263]$. Additionally, miR-21 can downregulate TLR-4-mediated inflammation through the inhibition of the expression of programmed cell death protein $4[39,281]$. miR29a and miR29b are also shown to be have elevated levels in MSC-Exos and play pivotal roles in regulation of TGF- $\beta$ and cell growth; in addition to the highly expressed miR-23a, the 29 family also has a large impact on angiogenesis [280,284].

Exosomes, and MSC-Exos specifically, show great potential for the promotion of rapid and efficient wound healing. Exosomes can be applied directly to an injury, which in animal models has been shown to promote collagen synthesis and the proliferation and migration of fibroblasts and keratinocytes (Table 8) [268,297,298]. These effects are shown to be due in part to exosomal regulations of microRNA levels and protease activities $[297,299]$. However, progressively more creative ways to utilize these versatile particles in novel technologies are being developed, such as the incorporation of exosomes into a gel, which is then applied to an injury. This treatment method has been shown to be more beneficial than a single, direct administration of exosomes due to a slow, steady rate of delivery, with some gels delivering exosomes for up to a week [300-302]. These scaffolds offer structure, hydration, and increased flexibility in treatment options, as hydrogels can been used for wounds from basic skin injuries to deep nerve damage [302,303]. In the continued development of wound healing strategies continue, the broad applicability and therapeutic benefits of exosomes will only expand the prospects and efficiency of wound healing technologies. 
Table 8. MSC-derived exosomes in wound healing therapies.

\begin{tabular}{|c|c|c|c|c|c|c|c|}
\hline Study & MSC Source & Particle Isolation & Particle Size & $\begin{array}{l}\text { MSC Exosome } \\
\text { Characterization }\end{array}$ & Model Species/Cells & $\begin{array}{l}\text { Intervention(s), Route, } \\
\text { and Dose }\end{array}$ & $\begin{array}{l}\text { Important Finding from } \\
\text { the Studies }\end{array}$ \\
\hline (Choi et al., 2019) [299] & $\begin{array}{c}\text { Human } \\
\text { adipose-derived (AD) } \\
\text { MSCs }\end{array}$ & Centrifugation, TFF & $133 \pm 14 \mathrm{~nm}$ & EM, WB, NTA & $\begin{array}{l}\text { UV damaged Human } \\
\text { dermal fibroblasts }\end{array}$ & $\begin{array}{c}1 \times 10^{8} \text { particles in } \\
1 \mathrm{~mL} \text { PBS }\end{array}$ & $\begin{array}{l}\text { Increased collagen and } \\
\text { elastin synthesis and } \\
\text { decreased MMP activity }\end{array}$ \\
\hline (Hu et al., 2016) [267] & Human ADMSCs & $\begin{array}{l}\text { Ultrafiltration and } \\
\text { ExoQuick-TC kit }\end{array}$ & $30-100 \mathrm{~nm}$ & EM, WB, NTA & Adult male Balb/c mice & $\begin{array}{l}\text { Injection of } 200 \mu \mathrm{g} \text { of } \\
\text { total exosome protein in } \\
200 \mu \mathrm{L} \text { PBS }\end{array}$ & $\begin{array}{l}\text { Increased wound healing by } \\
\text { regulating the migration, } \\
\text { proliferation, and collagen } \\
\text { synthesis of fibroblast }\end{array}$ \\
\hline $\begin{array}{c}\text { (Cooper et al., 2018) } \\
\text { [304] }\end{array}$ & Human ADMSCs & ExoQuick-TC kit & $90-100 \mathrm{~nm}$ & NTA & $\begin{array}{l}\text { Six-month-old male } \\
\text { Fischer } 344 \text { rats }\end{array}$ & $\begin{array}{l}\text { Injection of conditioned } \\
\text { media from ZenBio }{ }^{\mathrm{TM}} \\
\text { ADSC }(20 \mu \mathrm{L}) \text { or control } \\
\text { (unconditioned) media } \\
(20 \mu \mathrm{L})\end{array}$ & $\begin{array}{l}\text { Increased wound healing } \\
\text { through increased migration } \\
\text { and proliferation of } \\
\text { keratinocytes and } \\
\text { fibroblasts }\end{array}$ \\
\hline (Shi et al., 2020) [297] & Human ADMSCs & UC & $50-120 \mathrm{~nm}$ & EM, WB & Male C57BL mice & $\begin{array}{c}\text { Subcutaneous injection } \\
\text { of exosomes } / 200 \mu \mathrm{g} \text { in } \\
100 \mu \mathrm{L} \text { of PBS }\end{array}$ & $\begin{array}{c}\text { Enhanced wound healing } \\
\text { through inducing miR-128- } \\
\text { 3p/SIRT1-mediated } \\
\text { autophagy }\end{array}$ \\
\hline (Shabbir et al., 2015) [48] & $\begin{array}{l}\text { Human bone-marrow } \\
\text { (BM) MSCs }\end{array}$ & UC & $30-100 \mathrm{~nm}$ & EM, WB, NTA & $\begin{array}{l}\text { Human dermal } \\
\text { fibroblasts }\end{array}$ & $\begin{array}{l}0.1,1 \text {, and } 10 \mu \mathrm{g} \text { total } \\
\text { exosome protein in } \\
1 \mathrm{~mL} ; \text { PBS } / \text { details not } \\
\text { provided }\end{array}$ & $\begin{array}{l}\text { Increased migration and } \\
\text { proliferation of fibroblasts } \\
\text { and tube formation by } \\
\text { endothelial cells }\end{array}$ \\
\hline (Ding et al., 2019) [268] & Human BMMSCs & UC & $50-150 \mathrm{~nm}$ & EM, WB, NTA & $\begin{array}{c}\text { Adult male } \\
\begin{array}{c}\text { Sprague-Dawley (SD) } \\
\text { rats }\end{array}\end{array}$ & $\begin{array}{c}\text { Subcutaneous injection } \\
\text { of exosomes } / 100 \mu \mathrm{g} \text { in } \\
100 \mu \mathrm{L} \text { of PBS }\end{array}$ & $\begin{array}{c}\text { Enhanced wound healing } \\
\text { through elevated } \\
\text { proaniogenic activity }\end{array}$ \\
\hline (Zhang et al., 2016) [298] & $\begin{array}{l}\text { Human umbilical cord } \\
\text { (UC) MSCs }\end{array}$ & $\begin{array}{c}\text { Differential } \\
\text { centrifugation and } \\
\text { sucrose gradient UC }\end{array}$ & $30-100 \mathrm{~nm}$ & EM, NTA & Adult female SD rats & $\begin{array}{l}\text { Injection of } 200 \mu \mathrm{g} \text { of } \\
\text { total exosome protein in } \\
200 \mu \mathrm{L} \text { PBS }\end{array}$ & $\begin{array}{l}\text { Increased wound healing } \\
\text { through increased } \\
\text { proliferation, angiogenesis } \\
\text { of fibroblasts }\end{array}$ \\
\hline
\end{tabular}


Table 8. Cont.

\begin{tabular}{|c|c|c|c|c|c|c|c|}
\hline Study & MSC Source & Particle Isolation & Particle Size & $\begin{array}{l}\text { MSC Exosome } \\
\text { Characterization }\end{array}$ & Model Species/Cells & $\begin{array}{c}\text { Intervention(s), Route, } \\
\text { and Dose }\end{array}$ & $\begin{array}{l}\text { Important Finding from } \\
\text { the Studies }\end{array}$ \\
\hline (Fang et al., 2016) [305] & Human UCMSCs & $\begin{array}{c}\text { Differential } \\
\text { centrifugation and } \\
\text { sucrose gradient UC }\end{array}$ & $30-100 \mathrm{~nm}$ & WB, NTA & $\begin{array}{l}\text { Adult male ICR mice } \\
\text { (Swiss-Hauschka mice) } \\
\text { and nude mice } \\
\text { (BALB/c- } v)\end{array}$ & $\begin{array}{c}\text { Exosome-scaffold } \\
\text { transplantation } \\
\text { (HydroMatrix)/100 } \mu \mathrm{g} \\
\text { of total exosome protein } \\
\text { in } 100 \mu \mathrm{L} \text { PBS }\end{array}$ & $\begin{array}{l}\text { Enhanced wound healing } \\
\text { through supression of } \\
\text { myofibroblast } \\
\text { differentiation }\end{array}$ \\
\hline (Ti et al., 2015) [306] & Human UCMSCs & UC & $40-90 \mathrm{~nm}$ & EM, WB & $\begin{array}{l}\text { Diabetic rats (Details } \\
\text { not provided) }\end{array}$ & $\begin{array}{c}\text { Injection at wound } \\
\text { site } / \mathrm{MSC} \text {-exosomes } \\
(60 \mu \mathrm{g}) \text { and } \\
\text { LPS-preconditioned } \\
\text { MSC-exosomes }(60 \mu \mathrm{g})\end{array}$ & $\begin{array}{l}\text { Increased diabetic } \\
\text { cutaneous wound healing } \\
\text { through regulation of } \\
\text { macrophage polarization } \\
\text { and resolution of chronic } \\
\text { inflammation }\end{array}$ \\
\hline (Zhang et al., 2015) [50] & Human iPSC-MSCs & UC & $30-100 \mathrm{~nm}$ & $\mathrm{EM}, \mathrm{FC}, \mathrm{WB}$ & Adult male SD rats & $\begin{array}{l}\text { Injection } / 160 \mu \mathrm{g} \text { total } \\
\text { exosome protein in } \\
160 \mu \mathrm{L} ; \mathrm{PBS} \text { at wound } \\
\text { sites and } 40 \mu \mathrm{g} \text { total } \\
\text { exosome protein in } 40 \\
\mu \mathrm{L} \text { PBS at wound beds; } \\
\text { 14-day study }\end{array}$ & $\begin{array}{l}\text { Enhanced angiogenesis and } \\
\text { collagen synthesis }\end{array}$ \\
\hline (Li et al., 2016) [302] & Human synovium & UC & $85 \pm 36 \mathrm{~nm}$ & EM, DLS, WB & Adult male SD rats & $\begin{array}{l}\text { Hydroxyapatite/chitosan } \\
\text { composite hydrogels } \\
\text { loaded with exosomes }\end{array}$ & $\begin{array}{c}\text { Increased wound healing } \\
\text { through re-epithelialization, } \\
\text { accelerating angiogenesis, } \\
\text { and expediting collagen } \\
\text { maturity }\end{array}$ \\
\hline
\end{tabular}

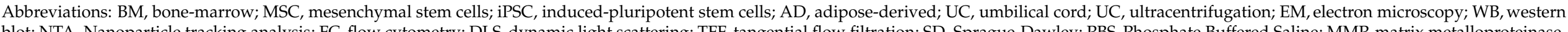

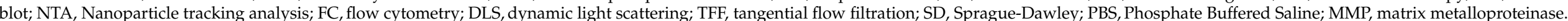




\section{Brain Injury}

Injuries to the brain, including traumatic brain injury (TBI) or stroke, can lead to longterm disability and decreased life expectancy, making them major health and economic issues $[46,308,309]$. These traumas can prompt rapid acute and long-term damage to neuronal tissue and function. Successful treatment of brain injuries is limited due to the need for swift diagnosis and difficulties in delivering therapeutics past the blood-brain barrier (BBB). Additional complications arise due to the myriad of changes that take place following brain damages. MSC-Exos are not only capable of crossing the BBB through intravenous or intranasal delivery, but also have beneficial effects in treating chronic inflammation in and promoting healthy healing, making them a potential therapeutic for complex brain injuries (Figure 6) [310-313].

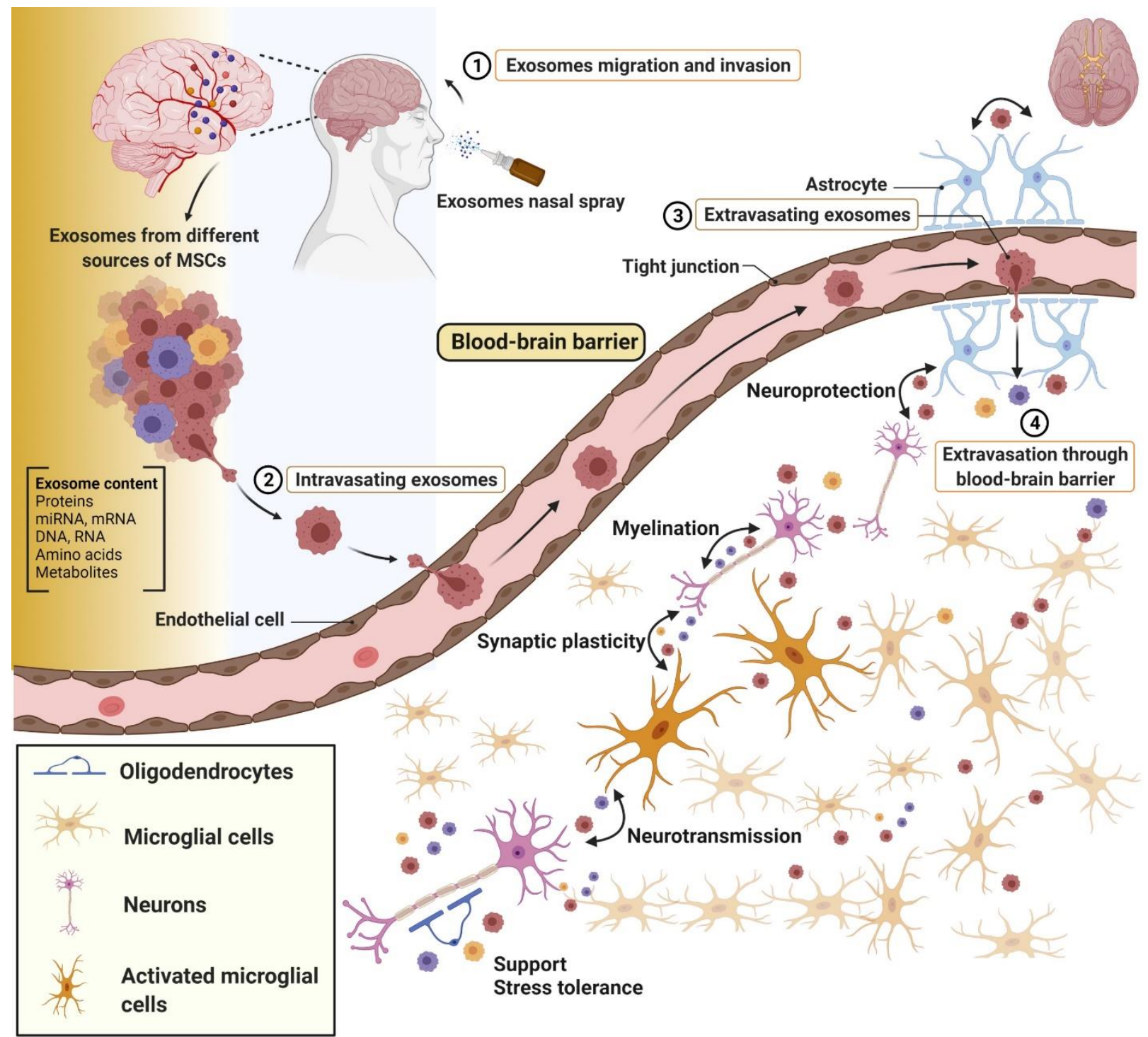

Figure 6. Schematic representation of functions of exosomes in neural cell communication. Exosomes released from different types of MSCs such as human umbilical cord, adipose tissue, bone marrow, and neural stem cells perform several investigated and suggested biological functions. Exosomes delivered via intranasal, intravenous, or other routes can migrate to the brain and penetrate the blood brain barrier. From there, the exosomes can enter general circulation and arrive at far off targets. Conversely, exosomes can travel across the blood brain barrier from inside the blood vessel into the central nervous system and be taken up by neurons and glial cells. Exosomes contain diverse contents (as depicted in Figure 1), that can influence inflammation, misfolded proteins, damage, and disease. In injury states such as TBI or stroke, exosomes interact with synaptic activity and neural survival, facilitating neurite outgrowth, and can promoting myelination and blood brain barrier repair. 
Impacts from sports, car crashes, military experiences, or falls can lead to damage to the brain called a concussion, or traumatic brain injury (TBI). Originally thought to be an acute event, research has now shown that TBIs can lead to long-lasting effects on brain function, reducing life expectancy [308,309,314]. TBIs produce immediate trauma to the brain in which neurons, glia, and blood vessels stretch or tear, inducing apoptosis and damaging the BBB. This is followed by a pro-inflammatory immune response that recruits glial cells to the injury site; upon arrival to the injury, immune cells become activated, phagocytose dead and damaged cells, and secrete pro-inflammatory signals. In moderate to severe injuries, this inflammatory immune response does not properly resolve, causing chronic inflammation: complications of chronic inflammation can last weeks to years following injury [46,308,314]. MSC-Exos from various sources including bone marrow, umbilical cord, and adipose tissue have shown great potential in modulating the inflammatory response that follows a TBI [46,51,315]. When MSC-Exos were delivered 24 hours after injury in a model of TBI, controlled cortical impact, researchers found a decreased inflammatory response, which led to improved recovery via enhanced neurogenesis and angiogenesis $[51,309,315]$. This effect is due in part to microRNAs contained within exosomes, such as $\mathrm{miR}-9, \mathrm{miR}-124$, and $\mathrm{miR}-125 \mathrm{~b}$. These microRNAs regulate important cytokines such as IL-1 $\beta$, and thus promote neurogenesis. Studies have found that treatment with exosomes can decrease inflammatory markers in a dose-dependent fashion [46,308,316,317]. Additionally, exosomes can regulate TLR-4 and macrophage polarization, thereby promoting recovery following a TBI $[46,136,314,317,318]$. Importantly, administration of MSC-Exos following a concussion can not only help the molecular changes that take place, but also lead to improvements in motor and cognitive deficits that commonly occur after brain damage [51,309,315,317-320].

Another common injury to the brain is a stroke, which is a major cause of morbidity globally, with 15 million estimated strokes every year worldwide [310,313,321,322]. There are different types of strokes which can be difficult to differentiate between creating complications in diagnoses, including ischemic (development of a clot that blocks blood flow to a part of the brain) and hemorrhagic (a blood vessel ruptures) [74,323,324]. Following a stroke, there is a loss of oxygen to the brain, cell death, and excess inflammation. Interestingly, exosomes are being considered as a potential biomarker for stroke severity, and importantly for diagnosis, stroke type [8,322,325]. Kalani et al. found that the microRNA content in secreted exosomes is contingent on the type of stroke a patient suffered from, with miRs such as miR-21-3p, miR-27b-3p, and miR-132-3p elevated in patients with an ischemic stroke [8]. In addition to exosomes serving as a stroke biomarker, MSC-Exos have highly beneficial properties in the treatment of stroke. The primary standard of ischemic stroke care is the delivery of tissue plasminogen activator (tPA); interestingly, the addition of exosomes to tPA treatment significantly improved functional outcome following stroke compared to tPA treatment alone [313,317]. Delivery of MSC-Exos in stroke models leads to long-term neuroprotection, improved neurogenesis and neurovascular remodeling, as well as enhanced behavioral and neurological performances in motor function, coordination, sensorimotor, and spatial learning [136,317,324,326-330]. Varied contents of exosomes have been shown to aid recuperation, from growth factors such as VEGF to microRNAs [46,331]. Zheng et al. identified that miR-25 in MSC-Exos improved cell viability following stroke through modulation of BCL2/adenovirus E1B $19 \mathrm{kDa}$ protein-interacting protein 3, while in a model of middle cerebral artery occlusion, miR-133b secreted from MSCs led to improved neurogenesis and stroke recovery $[46,310,311,330]$. Similar to studies in TBI, MSC-Exos can improve recovery through modulation of inflammation [43,136,310,313,328]. A study by Zhao et al. found that delivery of MSC exosomes significantly decreased inflammatory signaling and promoted the polarization of microglia from M1 to M2 activation [136]. miR-21, miR-199a, miR-124a, and miR-17 are a few of many exosomal microRNAs that have been shown to play beneficial roles in neuroprotection, immune regulation, and rejuvenation after injury [324,332]. Together, these studies demonstrate that exosomes are highly beneficial for neurological injuries, not only due to the vast therapeutic value 
provided by exosomal contents, but also because these vesicles can bypass the BBB through both intravenous and intranasal administration. See Figure 6 for depiction of exosomal role in brain healing.

\section{Hepatic Diseases}

Liver diseases include illnesses such as cirrhosis (the scarring of the liver) and hepatocellular carcinoma, and worldwide account for approximately 2 million deaths annually [333]. Treatments for liver diseases vary, but several studies related to acute liver injury and other hepatic diseases have identified that exosomes may have dual function of therapeutic agents as well as specific biomarkers for liver disease diagnosis [334-338]. Recently, a report from Momen-Heravi and group has demonstrated that in alcoholic hepatitis patients, the number of exosomes was found to be elevated compared to the healthy population [338]. Certain RNAs are differentially affected in exosomes derived from patients with liver diseases, with RNAs such as miR-21 elevated in exosomes of patients with hepatocellular carcinoma $[334,335,338,339]$. These findings set a stage for exosomes as biomarkers for noninvasive detection of hepatocellular carcinoma and other acute liver diseases [340-342].

The regenerative capacities of exosomes in liver have been explored as therapeutic agents, as exosomes carry cargo over large distances for cellular communication. Several studies have found that treatment with exosomes benefits liver repair and regeneration following hepatic failure, an effect thought to be due to the promotion of angiogenesis via the Wnt signaling pathway [343]. Further, hepatocyte-derived exosomes can deliver the synthetic machinery to form sphingosine-1-phosphate in target hepatocytes, enabling cell proliferation and liver regeneration after ischemia, reperfusion injuries, or after partial hepatectomy [344]. It has also demonstrated that hepatocyte-derived exosomes stimulate hepatocyte proliferation in vitro and promote liver regeneration in vivo during acute liver injury; the underlying mechanism is thought to involve exosome-mediated transfer of neutral ceramidase and sphingosine kinase 2 at the site of regeneration. Additionally, it was revealed that after liver injury, the enhanced levels of circulating exosomes have proliferative effects [344]. The regenerative potential of MSC-Exos in carbon tetrachloride (CCl4)-induced liver injury has also been investigated. It was found that these exosomes effectively attenuated the CCl4-induced liver injury by promoting proliferative and regenerative responses $[345,346]$. The potential effect of exosomes derived from human-induced pluripotent stem cell-derived mesenchymal stromal cells was studied in hepatic ischemiareperfusion injury. The administration of such exosomes showed promising effects in the recovery of hepatic ischemia-reperfusion injury, with suppressed inflammatory responses, attenuated oxidative stress responses, and inhibited cellular apoptosis, pointing to exosomes as a viable therapeutic option for liver diseases [347].

\section{Cardiovascular Diseases}

Cardiovascular diseases (CVDs), such as heart failure and coronary artery disease, are some of the prime causes of morbidities and mortalities in the United States, accounting for a total of around 655,000 attributable fatalities per year and are associated with immense health and financial expenditure [348,349]. Conventional CVD therapies primarily consist of transplantations and therapeutics; however, receiving a transplant can be a very drawnout process, and therapeutics have limited clinical efficacy. Therefore, focus has shifted to the development and validation of new therapeutics, with numerous cell-based therapeutic interventions initiated for the treatment of CVDs. Though cell-based treatment methods are promising, they face challenges such as low engraftment, poor survival rate of transplant cells, tumorigenesis potential, and immune rejection. Intriguingly, recent experimental data have suggested that myocardial protective functions through autocrine and/or paracrine actions of cell-based therapies may be achieved via through exosomes (Figure 7) [350,351]. Exosomes have major roles physiological and pathological cardiovascular processes including regulation of angiogenesis, cardiomyocyte hypertrophy, cardiac fibrosis, blood pressure 
control, and anti-apoptotic effect (survival) have been broadly acknowledged. Additionally, in the heart, cells including cardiomyocytes, cardiac fibroblasts, endothelial, vascular, cardiac progenitors, and stem cells release exosomes [352-360]. Moreover, exosomes lack some of the issues of cell-based therapies due to their low immunogenicity, minimal embolism risk, and biocompatibility, and can be delivered to the heart in a variety of ways, including engineered exosomes, endogenous exosomes, targeted exosomes, or exosomes contained in a patch [361,362]. The heart undergoes extensive cardiac remodeling following cardiac stressors such as myocardial infarction (MI), to restore contractile function. Numerous studies have indicated that after cardiac stressors, endogenous exosomes can ameliorate heart function (Figure 7) [363-365]. This demonstrates that exosomes can have effective therapeutic utility in the treatment of CVDs.

The therapeutic potential of exosome-based cell-free therapy for CVDs applies to several diseases including MI, atherosclerosis, and dilated cardiomyopathy. The cardioprotective effect of exosomes can be augmented by pretreatments like hypoxia preconditioning, gene programming, or drug intervention [294,366,367]. In MI increasing evidence has shown that the administration of exosomes can enhance cardiac repair. For example, a study has revealed that MSC-Exos improve cardiac function by down-regulating the expression of CD68 [163]. Exosomes obtained from miR-146a-modified adipose-derived stem cells (ADSCExos) have been shown to attenuates acute MI-induced myocardial damage by suppressing the local inflammatory response through inhibition of the release of proinflammatory cytokines (IL-6, IL- $1 \beta$, and TNF- $\alpha$ ). The same report further demonstrated that ADSCExos improves cardiac functions by arresting cardiomyocyte apoptosis via early growth response factor 1 downregulation [368]. Huang and coworkers have discovered that exosomes from atorvastatin (ATV)-pretreated MSC (MSCATV-Exos) ameliorated cardiac dysfunction and reduced infarct area by diminishing IL- 6 and TNF- $\alpha$ levels, promoting angiogenesis, and preventing apoptosis following MI. MSCATV-Exos are abundant in lncRNA H19 that regulates miR-675 expression and activation of pro-angiogenic factors [366]. Adipose-derived stromal cells (ADSC)-derived miR-93-5p-containing exosomes are also beneficial in the treatment of MI by conferring protection against autophagy, apoptosis, and inflammation [369]. Separately, in a mouse model of MI, hypoxia-derived exosomal miR125b-5p exerts cardioprotective function and enhances cardiac repair by suppressing the expression of pro-apoptotic genes $p 53$ and $B A K 1$, thus inhibiting cardiomyocyte apoptosis [370].

The therapeutic promise of exosomes has also been investigated in the treatment of atherosclerosis. MSC-Exos serve a protective role in hindering the progression of atherosclerosis by inducing $\mathrm{M} 1 \rightarrow \mathrm{M} 2$ macrophage polarization through up-regulation of miR-let7 [371], an effect also displayed in different animal models of ischemia-reperfusion (I/R) injury [372,373]. Post myocardial I/R injury, exosomes aid in cardiac repair and contract myocardial infarct size by limiting cardiac fibroblast proliferation, creating an anti-inflammation microenvironment, and improving cardiac function mainly via the shuttling of miRNAs (miR-182, miR-146a, miR-181b, and miR-126) [372,373]. In addition, Lankford and colleagues have shown that the MSC-Exos are effective in dilated cardiomyopathy, as exosomes reduce ventricular dilation by hampering inflammatory cytokines expression and enhancing the production of anti-inflammatory M2 macrophages over M1 macrophages [374]. In chronic heart failure, a study has shown significantly elevated exosomal miR-146 levels, which can inhibit the inflammatory response [375]. 


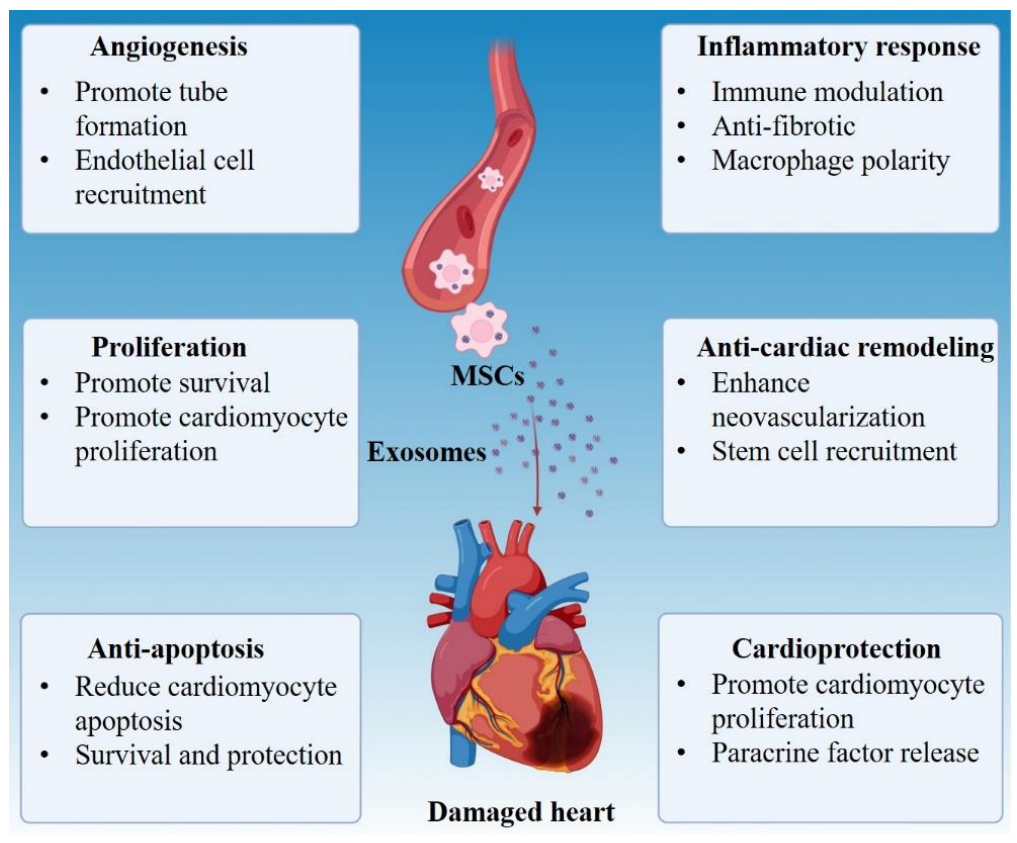

(A)

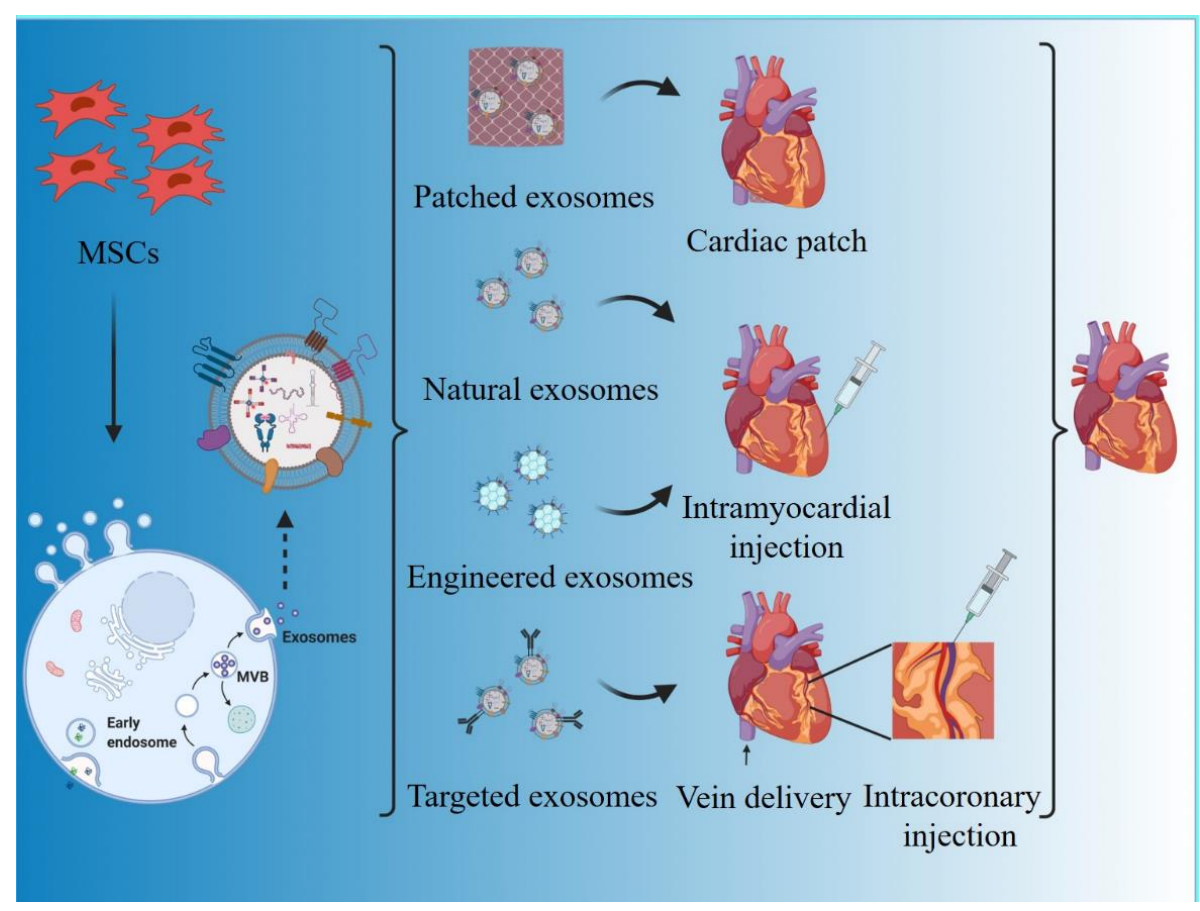

(B)

Figure 7. Stem cell-derived exosomes for cardiac repair therapies. (A) Exosomes isolated from different types of mesenchymal stem cells carry and deliver proteins, nucleic acids (DNA, miRNAs, mRNAs, and other RNAs) and metabolites to the damage heart tissue, consequently promoting cardioprotective effects. (B) Schematic representation of tissue engineering approaches in exosomebased cardiac repair therapies. MSCs or exosomes can be genetically modified with tRNA, miRNA or mRNA to express the desired gene using gene delivery methods or CRISPR/Cas9. MSC-derived exosomes can act as therapeutic vehicles to deliver biological molecules or drug molecules and further immersed in scaffolds and delivered as patch, injectable scaffold, or 3D tissue construct to increase the functions of exosomes. Similarly, exosomes can be chemically conjugated with targeted peptides to further enhance efficacy and retention when delivered intravenously. 
Though exosomes are heavily investigated for their therapeutic potential, they are also capable of propagating detrimental pathology in heart disease. In MI, miR-155enriched exosomes secreted by activated macrophages were found to negatively regulates fibroblast differentiation and promote inflammation, exacerbating cardiac rupture [376]. In atherosclerosis, Gao et al. reported that dendritic cell-derived exosomes induce the progression of atherosclerosis by triggering inflammatory responses [377]. Taken together, although these preliminary studies on CVDs have promising results, there are still many questions that must be answered before exosomal treatment can fully achieve a useful clinical outcome (Figure 7).

\section{Bone Regeneration}

Bone health is a rising issue and public health concern, as in the United States, approximately 850,000 people suffer from bone fractures per year [378,379], while approximately 25 million peoples are at high risk for injury due to low bone density [380,381]. In the bone remodeling and fracture healing process, osteoclasts reabsorb old or damaged bone, while new bone is synthesized by osteoblasts [381,382]. A healing cascade is initiated, leading to the recruitment of inflammatory cells, formation of new vessels, and establishment of hematoma at the fracture site [383]. The management of these bone fractures includes autologous and allogeneic transplantation; however, these procedures have a prolonged recovery time and thus increased likelihood of complications. In recent years, tissue engineering-based biomaterials and cell therapies have emerged as major players in the treatment of bone fractures. Research has identified that the biological effect of cell-based therapies is executed largely via exosomes, and as such, exosomal regulation of bone repair has become a viable therapeutic strategy. Exosomes are secreted by cell types including osteoblasts, osteoclasts, osteocytes, and bone marrow MSCs, which are known to mediate cellular communication and participate in the regulation of bone microenvironment [384-390]. Furthermore, numerous studies have corroborated the potential regulatory roles of exosomes in bone remodeling and fracture healing [381,382], suggesting exosomes can be utilized as individualized therapeutic strategies to promote bone tissue repair.

Exosomes derived from various sources have been demonstrated to be beneficial in bone repair. Chief amongst them are MSC-Exos, which play a promising role in the induction of osteo-differentiational activity through microRNA regulations [391]. Exosomes obtained from adipose tissue MSCs, preconditioned with TNF- $\alpha$, promote primary osteoblast differentiation by regulating the Wnt pathway [392]. Separately, exosomes derived from mineralizing osteoblast cells promote new bone growth through directly regulating osteoblast proliferation and stimulating the differentiation of osteoblast precursors into mature osteoblasts via mediating miRNA profiles. This successively activates downstream signaling pathways for bone formation and matrix mineralization [384]. Another group has reported that exosomes isolated from human-induced pluripotent stem cell-derived MSCs potently enhance osteo-inductivity of $\beta$-TCP through activation of PI3K/AKT pathway [393]. Further, this study demonstrated that in an immunocompetent rat osteochondral defect model, the MSC-Exos promote cartilage regeneration by enhancing early cellular infiltration and proliferation, inducing synovial macrophage polarization, and exhibiting anti-apoptotic activity [393].

Bone remodeling is a long-lasting process in which can exosomes play crucial regulatory roles. Exosomes derived from osteoblasts stimulate the differentiation of osteoclasts in vivo, and as such exosome treatment can be used to enhance the removal of damaged tissue [394,395]. It has also been revealed that in a femur fracture model of $\mathrm{CD}^{-} /^{-}$mice, which lacks exosome production, there is a delay of callus formation resulting in remission of a bone union. Providing further support for the beneficial role of exosomes in bone repair, the administration of MSC-Exos rescued this delayed repair [396]. The same study further explained that, when compared to exosomes isolated from MSCs cultured in preconditioned media, control exosomes were deprived of bone repair-related cytokines such as monocyte chemotactic protein-1(MCP-1), MCP-3, and stromal cell-derived factor-1 [396]. 
In a rat osteochondral defect model, the intra-articular administration of human embryonic MSC-Exos induces an enhanced gross appearance and improved histological scores; by 12 weeks of treatment, the cartilage and subchondral bone was fully restored [397]. In addition, studies have shown that overactivated inflammatory response or inflammation attenuation results in either bone tissue damage or accumulation of necrotic tissue, respectively [398-400]. MSC-Exos are shown to diminish inflammation-based delay of fracture healing by effectively suppressing levels of proinflammation factors IL- $1 \beta$ and TNF- $\alpha$, whereas increasing levels of anti-inflammatory factor TGF- $\beta$ [401].

Vascularization is an important event in bone formation as it improves diffusion of oxygen and nutritional components that are crucial for new bone formation [402]. Various reports have demonstrated the involvement exosomes in the activities of endothelial cells (ECs) including migration, proliferation, and tube formation. Exosomes derived from endothelial progenitor cells induce the formation of vessel-like structures both in vitro and in vivo by activating eNOS and PI3K/AKT pathways in human umbilical vein endothelial cells and human mammalian ECs [403]. In addition, the contribution of MSC-Exos in angiogenesis is well established [404,405]. Researchers have shown that MSC-Exos are internalized into tissue engineering-based matrix, which results in pro-angiogenic and pro-osteogenic activities, suggesting exosomes may regulate synergistic bone regeneration and enhance angiogenesis [406]. Moreover, in an in vivo study, MSC-Exos delivered to osteoporotic rats had elevated angiogenesis and osteogenesis eight weeks post-administration [407]. However, the coupling underlying mechanisms of angiogenesis and osteogenesis is still unclear.

A primary mechanism of action is osteopathic repair is through microRNA activity and regulation, many of which have been identified within exosomes. For example, researchers have identified that miR-199b is involved in the regulation of Runx 2, a master transcription factor for osteoblast and osteocyte differentiation [391]. Let-7 positively regulates osteogenesis and new bone formation by downregulating high-mobility group AT-hook 2 expression [408], while upregulated levels of miR-135b significantly inhibit osteogenic differentiation of MSCs [409]. In both human MSCs and human unrestricted somatic stem cells, miR-221 downregulation showed to stimulate osteogenic differentiation [410]. The crucial role of miR-21 in enhancing the rate of fracture healing has also been illustrated in a rat closed femur fracture model [411]. miR-21 rich exosomes possess anti-apoptotic properties and can contribute to osteoblastogenesis through the regulation of small mothers against decapentaplegic 7 (Smad7) and modulating PI3K/ $\beta$-catenin pathways [412,413]. Exosomes can also serve as a biomarker, as altered miRNA profiles in MSC-Exos have been discovered during osteogenesis [391]. Therefore, the involvement of specialized cargo within exosomes enriched with specific factors such as miRNA, cytokines, or growth factors can play vital roles during bone repair and diagnostics [396]. This collective data and positive outcomes provided new insight for exosome-based synergetic therapy for bone fracture healing.

\section{COVID-19}

In late 2019, Chinese health authorities reported an outbreak of pneumonia of unknown origin in the city of Wuhan [414-416]. This led to the occurrence of a global pandemic, now known as COVID-19, resulting in thousands of deaths and infecting millions of people across the world (https: / / coronavirus.jhu.edu/map.html accessed 25 June 2021). COVID-19 has had an enormous destabilizing impact on society, including the healthcare sector and economies of even the most developed nations. A novel coronavirus named 2019-nCoV (later renamed as SARS-CoV-2) is known to be the causative agent and was first isolated from the airway epithelial cells of a patient [414-416]. SARS-CoV-2 was first sequenced in China and found to be different from previously identified viruses including MERS-CoV and SARS-CoV. It is now considered as the seventh member of the family of coronaviruses that are known to infect humans. SARS-CoV-2 is mainly transmitted via droplets within individuals of a susceptible population. It has also been shown to 
survive on glass and banknotes surfaces for 24-72 h [417]. However, the exact molecular mechanism of infection from SARS-CoV-2 is currently unknown.

MSCs have been substantially investigated as useful tools for stem cell-based therapy of degenerative diseases, cardiovascular disease, and lung diseases due to properties such as high proliferation rate, high differentiation, and vast source potential. Recently, several studies have posited that COVID-19 can hijack the immune system of the body and trigger an overreaction, ultimately leading to extreme inflammation and organ damage. In COVID19 , following its infection of the lungs, SARS CoV-2 virus triggers an immune response of cytokine secretion along with other immune cells, resulting in a hyper inflammation condition called cytokine storm. Numerous studies have shown that MSCs can interact with and regulate the function of immune cells such as B cells, DCs, natural killer cells, macrophages, T cells, and neutrophils [418-420]. In COVID-19, the SARS-CoV-2 enters the body by binding to angiotensin-converting enzyme 2 (ACE2), an enzyme located on the membrane of many cell types, including those in the lung [421,422]. MSCs do not contain any ACE2 receptors, making them immune to SARS-CoV-2. Recent research has found that transplanting MSCs in COVID-19 patients has immunomodulatory effects that can prevent the cytokine storm and decrease the damage to tissues through the regenerative potential of MSCs [423,424].

Interestingly, several studies have demonstrated that exosomes derived from MSCs suppress cytokine release and reduce the level of inflammation [418,425,426]. In addition to this, Dinh et al. showed that exosomes can help in lung regeneration in pulmonary fibrosis conditions [250]. Therefore, exosomes could possibly be used in the treatment of critically ill COVID-19 patients in combination with other therapies (Figure 8). To date, more than 90 MSCs based studies for respiratory diseases have been registered for clinical trials (https:/ / clinicaltrials.gov, accessed 25 June 2021). In addition, Ruijin hospital in China registered a pilot clinical study to explore the inhalation of exosomes derived from allogenic adipose MSCs in patients critically ill with COVID-19 (ClinicalTrials.gov Identifier: NCT04276987). Similarly, several other, similar clinical trial studies have been registered worldwide (Table 9). Therefore, there is growing evidence that the use of MSC-Exos in COVID-19 therapy may limit the respiratory complications in patients.

Table 9. List of registered exosome cell based clinical trials for the treatment of COVID-19.

\begin{tabular}{|c|c|c|c|}
\hline Registration Number & Study Topic & Cell Source & Type of Study \\
\hline NCT04276987 & $\begin{array}{l}\text { A Pilot Clinical Study on Inhalation } \\
\text { of Mesenchymal Stem Cells } \\
\text { Exosomes Treating Severe Novel } \\
\text { Coronavirus Pneumonia }\end{array}$ & $\begin{array}{l}\text { Adipose MSC-derived } \\
\text { exosome }\end{array}$ & $\begin{array}{c}\text { Biological: } \\
\text { MSCs-derived exosomes }\end{array}$ \\
\hline NCT04493242 & $\begin{array}{l}\text { Extracellular Vesicle Infusion } \\
\text { Therapy for Severe COVID-19 } \\
\text { (EXIT COVID-19) }\end{array}$ & $\begin{array}{l}\text { Bone marrow derived } \\
\text { extracellular vesicles. }\end{array}$ & Intervention study \\
\hline NCT04389385 & $\begin{array}{l}\text { COVID-19 Specific T Cell Derived } \\
\text { Exosomes (CSTC-Exo) }\end{array}$ & $\begin{array}{c}\text { COVID-19 Specific T Cell } \\
\text { derived exosomes (CSTC-Exo) }\end{array}$ & Intervention study \\
\hline NCT04384445 & $\begin{array}{l}\text { Zofin (Organicell Flow) for Patients } \\
\text { With COVID-19 } \\
\text { Safety and Efficacy of Exosomes }\end{array}$ & $\begin{array}{l}\text { Human amniotic fluid } \\
\text { derived exosomes }\end{array}$ & Intervention study \\
\hline NCT04902183 & $\begin{array}{c}\text { Overexpressing CD24 in Two Doses } \\
\text { for Patients With Moderate or } \\
\text { Severe COVID-19 }\end{array}$ & - & Intervention study \\
\hline NCT04747574 & $\begin{array}{l}\text { Evaluation of the Safety of } \\
\text { CD24-Exosomes in Patients With } \\
\text { COVID-19 Infection }\end{array}$ & - & Intervention study \\
\hline NCT04491240 & $\begin{array}{c}\text { Evaluation of Safety and Efficiency } \\
\text { of Method of Exosome Inhalation in } \\
\text { SARS-CoV-2 Associated } \\
\text { Pneumonia. (COVID-19EXO) }\end{array}$ & - & Intervention study \\
\hline
\end{tabular}


Table 9. Cont.

\begin{tabular}{|c|c|c|c|}
\hline Registration Number & Study Topic & Cell Source & Type of Study \\
\hline NCT04798716 & $\begin{array}{l}\text { The Use of Exosomes for the } \\
\text { Treatment of Acute Respiratory } \\
\text { Distress Syndrome or Novel } \\
\text { Coronavirus Pneumonia Caused by } \\
\text { COVID-19 (ARDOXSO) }\end{array}$ & MSC-exosomes & Intervention study \\
\hline NCT04657406 & $\begin{array}{c}\text { Expanded Access to ZofinTM } \\
\text { (OrganicellTM Flow) for Patients } \\
\text { With COVID-19 }\end{array}$ & MSC-exosomes & Intervention study \\
\hline ChiCTR2000030484 & $\begin{array}{l}\text { Clinical application of umbilical } \\
\text { cord mesenchymal stem cells } \\
\text { combined with intravenous } \\
\text { exosome infusion to repair lung } \\
\text { injury of new coronavirus } \\
\text { pneumonia (COVID-19) }\end{array}$ & $\begin{array}{l}\text { Adipose MSC-derived } \\
\text { exosome }\end{array}$ & Intervention study \\
\hline ChiCTR2000030261 & & $\begin{array}{l}\text { Bone marrow derived } \\
\text { extracellular vesicles. }\end{array}$ & Intervention study \\
\hline
\end{tabular}

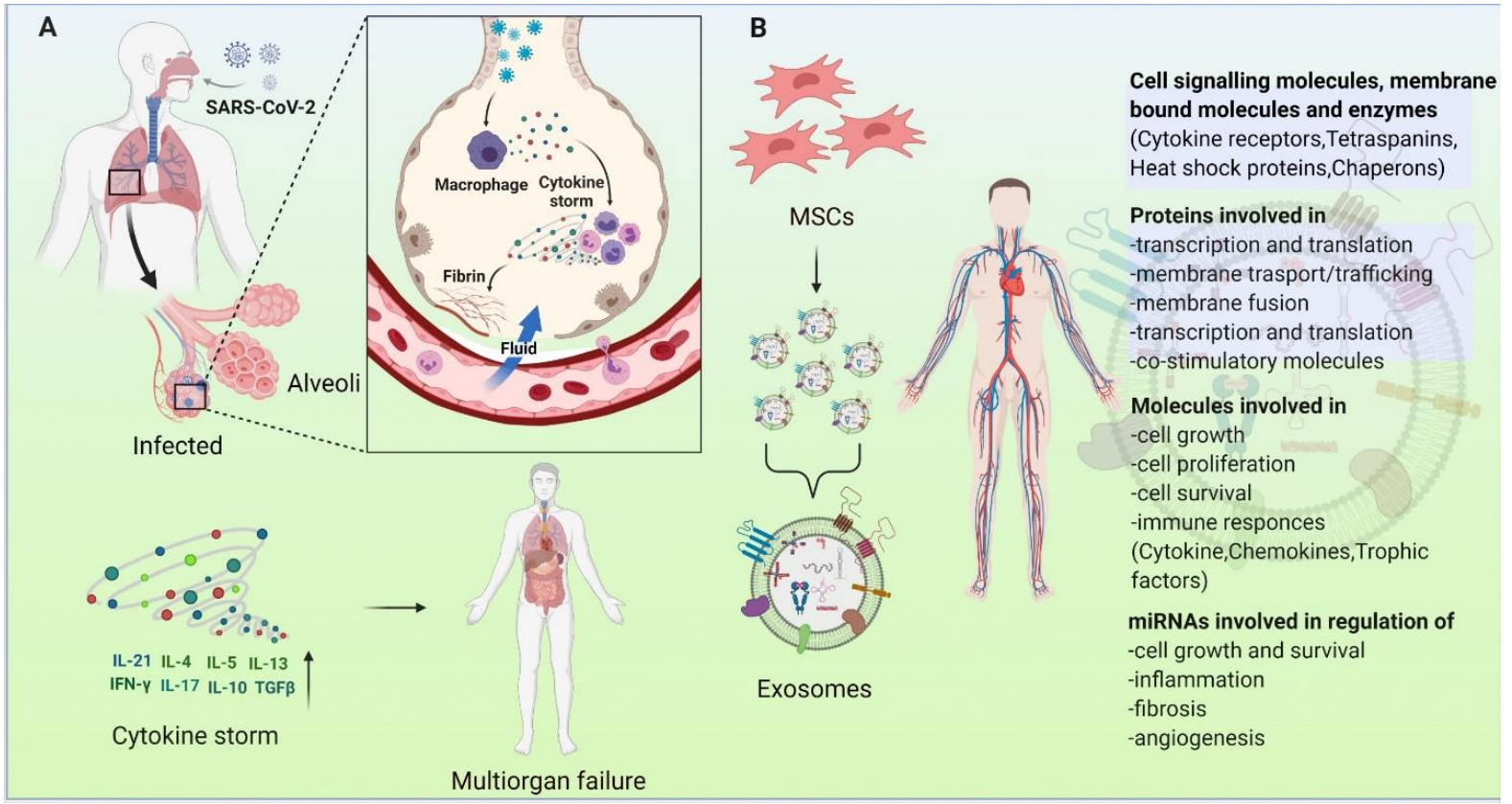

Figure 8. Schematic representation of role of cytokine storm in SARS-CoV-2 infection and possible therapeutic effects of MSCs and MSC-derived exosomes. (A) Pathogenesis of SARS-CoV-2; SARS-CoV-2 virus targets the lung epithelial cells. During this process, immune cells such as macrophages identify the virus particles and start to produce pro-inflammatory cytokines. These cytokines attract more immune cells, which in turn enhance the cytokine production. This creates a cycle of inflammation that damages the lung cells through the formation of fibrin. This damage results in weakened blood vessels, allowing fluid to seep in and fill the lung cavities, leading to respiratory failure and failure in multiple organs. MSCs and MSC-derived exosomes have the potent ability to suppress the inflammatory responses and prevent the progression towards multiple organ failure. (B) Putative mechanisms of MSC and MSC-derived exosome therapy in severe SARS-CoV2 cases; MSCs and MSC-derived exosomes have the potent ability to suppress the inflammatory responses and prevent the progression towards multiple organ failure. Isolated MSCs cultured in conditioned media that induces the release of exosomes. The MSCs identify the extracellular signals and start the packaging of several regulatory factors into exosomes that are released into the conditioned medium. These exosomes contain different growth factors, metabolic enzymes, molecules involved in immunomodulation, cytokine receptors, molecules important for cell division and proliferation, DNA, and regulatory miRNAs. In MSC-derived exosome therapy, exosomes are administered intravenously or via aerosol inhalation. The administered exosomes inhibit inflammatory cytokines and other immune regulatory cells which results in the suppression of the cytokine storm. 


\section{Conclusions and Perceptive}

In recent years, it has been established that exosomes have modulatory potential and play a critical role in diverse biological processes. Exosomes show tremendous therapeutic potential for disorders including chronic wound healing, neurological damages, and cardiovascular dysfunction. Exosomes have also gained widespread attention in the field of biomarker research and are now even being seen as an alternative strategy to stem cell-based regenerative therapies. Exosomes can be genetically engineered to deliver distinct therapeutic moieties to a desired target. These cargos include recombinant proteins, antagomirs, short interfering RNAs, antisense oligonucleotides, and immune modulators [427].

Although exosomes have attained significant achievements in several therapies, challenges remain. While numerous proteins, RNAs, lipids, and metabolic enzymes (Tables 2-4) have been identified in exosomes, little is known about their functions and sorting mechanisms. Exosomal cargo is also highly dependent on surrounding milieu and metabolic status of host cells. It remains ambiguous whether natural, physiological levels of small vesicles exert any pathological or regulatory roles in vivo. Despite several exosomal studies in chronic wound healing and skin regeneration, the exact molecular mechanism and the role of exosomes in these processes require further investigations. Additionally, for better exploitation of exosomes, an extensive study is needed in the areas of biogenesis, cellular uptake, and trafficking of exosomes. Moreover, other critical challenges involving the use of exosomes in regenerative medicine require further investigations, such as isolation, purification, optimization, standardization, quality control, and further exploration of molecular mechanisms of exosome communication with target cells. Overall, the potential of exosomes derived from various sources in regenerative medicine and tissue engineering is highly promising.

Author Contributions: Conceptualization, M.D.H. and C.N.S.; Writing-Original Draft Preparation, M.D.H. and C.N.S.; Visualization, M.D.H.; Writing—Review and Editing, M.D.H., C.N.S., and Z.S. Supervision, Z.S.; Funding Acquisition, Z.S. All authors have read and agreed to the published version of the manuscript.

Funding: This work was supported by the Florida State University startup fund to Z.S.

Institutional Review Board Statement: Not applicable.

Informed Consent Statement: Not applicable.

Data Availability Statement: No new data were created in this study. Data sharing is not applicable to this article.

Conflicts of Interest: The authors have declared that no conflict of interest exists.

\section{References}

1. Stremersch, S.; Vandenbroucke, R.E.; Van Wonterghem, E.; Hendrix, A.; De Smedt, S.C.; Raemdonck, K. Comparing exosome-like vesicles with liposomes for the functional cellular delivery of small RNAs. J. Control. Release 2016, 232, 51-61. [CrossRef]

2. Théry, C.; Zitvogel, L.; Amigorena, S. Exosomes: Composition, biogenesis and function. Nat. Rev. Immunol. 2002, 2, 569-579. [CrossRef] [PubMed]

3. Witwer, K.W.; Buzás, E.I.; Bemis, L.T.; Bora, A.; Lässer, C.; Lötvall, J.; Nolte-'t Hoen, E.N.; Piper, M.G.; Sivaraman, S.; Skog, J.; et al. Standardization of sample collection, isolation and analysis methods in extracellular vesicle research. J. Extracell. Vesicles 2013, 2. [CrossRef] [PubMed]

4. $\quad$ Blans, K.; Hansen, M.S.; Sørensen, L.V.; Hvam, M.L.; Howard, K.A.; Moeller, A.; Wiking, L.; Larsen, L.B.; Rasmussen, J.T. Pellet-free isolation of human and bovine milk extracellular vesicles by size-exclusion chromatography. J. Extracell. Vesicles 2017, 6, 1294340. [CrossRef] [PubMed]

5. Clayton, A.; Boilard, E.; I Buzas, E.; Cheng, L.; Falcón-Perez, J.M.; Gardiner, C.; Gustafson, D.; Gualerzi, A.; Hendrix, A.; Hoffman, A.; et al. Considerations towards a roadmap for collection, handling and storage of blood extracellular vesicles. J. Extracell. Vesicles 2019, 8, 1647027. [CrossRef] [PubMed]

6. Gallo, A.; Tandon, M.; Alevizos, I.; Illei, G.G. The Majority of MicroRNAs Detectable in Serum and Saliva Is Concentrated in Exosomes. PLoS ONE 2012, 7, e30679. [CrossRef] 
7. Iwai, K.; Minamisawa, T.; Suga, K.; Yajima, Y.; Shiba, K. Isolation of human salivary extracellular vesicles by iodixanol density gradient ultracentrifugation and their characterizations. J. Extracell. Vesicles 2016, 5, 30829. [CrossRef]

8. Kalani, M.Y.S.; Alsop, E.; Meechoovet, B.; Beecroft, T.; Agrawal, K.; Whitsett, T.; Huentelman, M.J.; Spetzler, R.F.; Nakaji, P.; Kim, S.; et al. Extracellular microRNAs in blood differentiate between ischaemic and haemorrhagic stroke subtypes. J. Extracell. Vesicles 2020, 9, 1713540. [CrossRef]

9. Simpson, R.J.; Lim, J.W.; Moritz, R.L.; Mathivanan, S. Exosomes: Proteomic insights and diagnostic potential. Expert Rev. Proteom. 2009, 6, 267-283. [CrossRef]

10. Srinivasan, S.; Duval, M.; Kaimal, V.; Cuff, C.; Clarke, S.H. Assessment of methods for serum extracellular vesicle small RNA sequencing to support biomarker development. J. Extracell. Vesicles 2019, 8, 1684425. [CrossRef] [PubMed]

11. Taylor, D.D.; Gercel-Taylor, C. MicroRNA signatures of tumor-derived exosomes as diagnostic biomarkers of ovarian cancer. Gynecol. Oncol. 2008, 110, 13-21. [CrossRef]

12. Zonneveld, M.; Brisson, A.R.; van Herwijnen, M.; Tan, S.; Van De Lest, C.H.A.; Redegeld, F.A.; Garssen, J.; Wauben, M.; Hoen, E.N.M.N.-. 'T Recovery of extracellular vesicles from human breast milk is influenced by sample collection and vesicle isolation procedures. J. Extracell. Vesicles 2014, 3. [CrossRef] [PubMed]

13. Harding, C.; Stahl, P. Transferrin recycling in reticulocytes: $\mathrm{pH}$ and iron are important determinants of ligand binding and processing. Biochem. Biophys. Res. Commun. 1983, 113, 650-658. [CrossRef]

14. Pan, B.-T.; Johnstone, R.M. Fate of the transferrin receptor during maturation of sheep reticulocytes in vitro: Selective externalization of the receptor. Cell 1983, 33, 967-978. [CrossRef]

15. Pan, B.T.; Teng, K.; Wu, C.; Adam, M.; Johnstone, R.M. Electron microscopic evidence for externalization of the transferrin receptor in vesicular form in sheep reticulocytes. J. Cell Biol. 1985, 101, 942-948. [CrossRef]

16. Johnstone, R.M.; Adam, M.; Hammond, J.R.; Orr, L.; Turbide, C. Vesicle formation during reticulocyte maturation. Association of plasma membrane activities with released vesicles (exosomes). J. Biol. Chem. 1987, 262, 9412-9420. [CrossRef]

17. Bobrie, A.; Colombo, M.; Raposo, G.; Théry, C. Exosome Secretion: Molecular Mechanisms and Roles in Immune Responses. Traffic 2011, 12, 1659-1668. [CrossRef] [PubMed]

18. Johnstone, R.M. Maturation of reticulocytes: Formation of exosomes as a mechanism for shedding membrane proteins. Biochem. Cell Biol. 1992, 70, 179-190. [CrossRef] [PubMed]

19. Pant, S.; Hilton, H.; Burczynski, M.E. The multifaceted exosome: Biogenesis, role in normal and aberrant cellular function, and frontiers for pharmacological and biomarker opportunities. Biochem. Pharmacol. 2012, 83, 1484-1494. [CrossRef]

20. Colombo, M.; Raposo, G.; Théry, C. Biogenesis, secretion, and intercellular interactions of exosomes and other extracellular vesicles. Annu. Rev. Cell Dev. Biol. 2014, 30, 255-289. [CrossRef]

21. Miller, I.V.; Grünewald, T.G.P. Tumour-derived exosomes: Tiny envelopes for big stories. Biol. Cell 2015, 107, 287-305. [CrossRef] [PubMed]

22. Bunggulawa, E.J.; Wang, W.; Yin, T.; Wang, N.; Durkan, C.; Wang, Y.; Wang, G. Recent advancements in the use of exosomes as drug delivery systems 06 biological sciences 0601 biochemistry and cell biology. J. Nanobiotechnol. 2018, 16, 81. [CrossRef]

23. Ha, D.; Yang, N.; Nadithe, V. Exosomes as therapeutic drug carriers and delivery vehicles across biological membranes: Current perspectives and future challenges. Acta Pharm. Sin. B 2016, 6, 287-296. [CrossRef]

24. O'Loughlin, C.A.W.A.M.J.W.A.J.; Woffindale, C.; Wood, M. Exosomes and the Emerging Field of Exosome-Based Gene Therapy. Curr. Gene Ther. 2012, 12, 262-274. [CrossRef] [PubMed]

25. Saari, H.; Turunen, T.; Lõhmus, A.; Turunen, M.; Jalasvuori, M.; Butcher, S.J.; Ylä-Herttuala, S.; Viitala, T.; Cerullo, V.; Siljander, P.R.M.; et al. Extracellular vesicles provide a capsid-free vector for oncolytic adenoviral DNA delivery. J. Extracell. Vesicles 2020, 9 , 1747206. [CrossRef]

26. Lai, R.C.; Yeo, R.W.Y.; Tan, K.H.; Lim, S.K. Exosomes for drug delivery-A novel application for the mesenchymal stem cell. Biotechnol. Adv. 2013, 31, 543-551. [CrossRef]

27. Min, L.; Zhu, S.; Chen, L.; Liu, X.; Wei, R.; Zhao, L.; Yang, Y.; Zhang, Z.; Kong, G.; Li, P.; et al. Evaluation of circulating small extracellular vesicles derived miRNAs as biomarkers of early colon cancer: A comparison with plasma total miRNAs. J. Extracell. Vesicles 2019, 8, 1643670. [CrossRef] [PubMed]

28. Bjørge, I.M.; Kim, S.Y.; Mano, J.F.; Kalionis, B.; Chrzanowski, W. Extracellular vesicles, exosomes and shedding vesicles in regenerative medicine-A new paradigm for tissue repair. Biomater. Sci. 2018, 6, 60-78. [CrossRef]

29. Yin, K.; Wang, S.; Zhao, R.C. Exosomes from mesenchymal stem/stromal cells: A new therapeutic paradigm. Biomark. Res. 2019, 7, 1-8. [CrossRef] [PubMed]

30. Lin, F. Adipose tissue-derived mesenchymal stem cells: A fat chance of curing kidney disease? Kidney Int. 2012, 82, 731-733. [CrossRef]

31. A Pelekanos, R.; Sardesai, V.S.; Futrega, K.; Lott, W.B.; Kuhn, M.; Doran, M.R. Isolation and Expansion of Mesenchymal Stem/Stromal Cells Derived from Human Placenta Tissue. J. Vis. Exp. 2016, 10, e54204. [CrossRef] [PubMed]

32. Erices, A.; Conget, P.; Minguell, J.J. Mesenchymal progenitor cells in human umbilical cord blood. Br. J. Haematol. 2000, 109, 235-242. [CrossRef] [PubMed]

33. Alonso-Goulart, V.; Ferreira, L.B.; Duarte, C.A.; de Lima, I.L.; Ferreira, E.R.; de Oliveira, B.C.; Vargas, L.N.; de Moraes, D.D.; Silva, I.B.B.; Faria, R.D.O.; et al. Mesenchymal stem cells from human adipose tissue and bone repair: A literature review. Biotechnol. Res. Innov. 2018, 2, 74-80. [CrossRef] 
34. Meirelles, L.D.S.; Chagastelles, P.C.; Nardi, N.B. Mesenchymal stem cells reside in virtually all post-natal organs and tissues. J. Cell Sci. 2006, 119 Pt 11, 2204-2213. [CrossRef]

35. Gang, E.J.; Jeong, J.A.; Hong, S.H.; Hwang, S.H.; Kim, S.W.; Yang, I.H.; Ahn, C.; Han, H.J.; Kim, H. Skeletal Myogenic Differentiation of Mesenchymal Stem Cells Isolated from Human Umbilical Cord Blood. Stem Cells 2004, 22, 617-624. [CrossRef]

36. Crapnell, K.; Blaesius, R.; Hastings, A.; Lennon, D.P.; Caplan, A.; Bruder, S.P. Growth, differentiation capacity, and function of mesenchymal stem cells expanded in serum-free medium developed via combinatorial screening. Exp. Cell Res. 2013, 319, 1409-1418. [CrossRef]

37. De Mayo, T.; Conget, P.; Becerra-Bayona, S.M.; Sossa, C.; Galvis, V.; Arango-Rodríguez, M.L. The role of bone marrow mesenchymal stromal cell derivatives in skin wound healing in diabetic mice. PLoS ONE 2017, 12, e0177533. [CrossRef]

38. Gnecchi, M.; Danieli, P.; Malpasso, G.; Ciuffreda, M.C. Paracrine Mechanisms of Mesenchymal Stem Cells in Tissue Repair. Methods Mol. Biol. 2016, 1416, 123-146. [CrossRef]

39. Kucharzewski, M.; Rojczyk, E.; Wilemska-Kucharzewska, K.; Wilk, R.; Hudecki, J.; Los, M.J. Novel trends in application of stem cells in skin wound healing. Eur. J. Pharmacol. 2019, 843, 307-315. [CrossRef]

40. Lou, P.; Liu, S.; Xu, X.; Pan, C.; Lu, Y.; Liu, J. Extracellular vesicle-based therapeutics for the regeneration of chronic wounds: Current knowledge and future perspectives. Acta Biomater. 2021, 119, 42-56. [CrossRef] [PubMed]

41. Walter, M.; Wright, K.; Fuller, H.; MacNeil, S.; Johnson, W. Mesenchymal stem cell-conditioned medium accelerates skin wound healing: An in vitro study of fibroblast and keratinocyte scratch assays. Exp. Cell Res. 2010, 316, 1271-1281. [CrossRef] [PubMed]

42. Barreca, M.M.; Cancemi, P.; Geraci, F. Mesenchymal and Induced Pluripotent Stem Cells-Derived Extracellular Vesicles: The New Frontier for Regenerative Medicine? Cells 2020, 9, 1163. [CrossRef]

43. Drommelschmidt, K.; Serdar, M.; Bendix, I.; Herz, J.; Bertling, F.; Prager, S.; Keller, M.; Ludwig, A.-K.; Duhan, V.; Radtke, S.; et al. Mesenchymal stem cell-derived extracellular vesicles ameliorate inflammation-induced preterm brain injury. Brain Behav. Immun. 2017, 60, 220-232. [CrossRef]

44. Nakano, M.; Nagaishi, K.; Konari, N.; Saito, Y.; Chikenji, T.S.; Mizue, Y.; Fujimiya, M. Bone marrow-derived mesenchymal stem cells improve diabetes-induced cognitive impairment by exosome transfer into damaged neurons and astrocytes. Sci. Rep. 2016, 6, 24805. [CrossRef]

45. Rani, S.; Ryan, A.E.; Griffin, M.D.; Ritter, T. Mesenchymal Stem Cell-derived Extracellular Vesicles: Toward Cell-free Therapeutic Applications. Mol. Ther. 2015, 23, 812-823. [CrossRef] [PubMed]

46. Yang, Y.; Ye, Y.; Su, X.; He, J.; Bai, W.; He, X. MSCs-Derived Exosomes and Neuroinflammation, Neurogenesis and Therapy of Traumatic Brain Injury. Front. Cell. Neurosci. 2017, 11. [CrossRef] [PubMed]

47. Lai, R.C.; Arslan, F.; Lee, M.M.; Sze, N.S.K.; Choo, A.; Chen, T.S.; Salto-Tellez, M.; Timmers, L.; Lee, C.N.; El Oakley, R.M.; et al. Exosome secreted by MSC reduces myocardial ischemia/reperfusion injury. Stem Cell Res. 2010, 4, 214-222. [CrossRef] [PubMed]

48. Shabbir, A.; Cox, A.; Rodriguez-Menocal, L.; Salgado, M.; Van Badiavas, E. Mesenchymal Stem Cell Exosomes Induce Proliferation and Migration of Normal and Chronic Wound Fibroblasts, and Enhance Angiogenesis In Vitro. Stem Cells Dev. 2015, 24, $1635-1647$. [CrossRef]

49. Zhang, B.; Yin, Y.; Lai, R.C.; Tan, S.S.; Choo, A.B.H.; Lim, S.K. Mesenchymal Stem Cells Secrete Immunologically Active Exosomes. Stem Cells Dev. 2014, 23, 1233-1244. [CrossRef] [PubMed]

50. Zhang, J.; Guan, J.; Niu, X.; Shangchun, G.; Guo, S.; Li, Q.; Xie, Z.; Zhang, C.; Wang, Y. Exosomes released from human induced pluripotent stem cells-derived MSCs facilitate cutaneous wound healing by promoting collagen synthesis and angiogenesis. $J$. Transl. Med. 2015, 13, 49. [CrossRef]

51. Zhang, Y.; Chopp, M.; Meng, Y.; Katakowski, M.; Xin, H.; Mahmood, A.; Xiong, Y. Effect of exosomes derived from multipluripotent mesenchymal stromal cells on functional recovery and neurovascular plasticity in rats after traumatic brain injury. $J$. Neurosurg. 2015, 122, 856-867. [CrossRef]

52. Bakhtyar, N.; Jeschke, M.G.; Mainville, L.; Herer, E.; Amini-Nik, S. Acellular Gelatinous Material of Human Umbilical Cord Enhances Wound Healing: A Candidate Remedy for Deficient Wound Healing. Front. Physiol. 2017, 8, 200. [CrossRef]

53. Brossa, A.; Fonsato, V.; Grange, C.; Tritta, S.; Tapparo, M.; Calvetti, R.; Cedrino, M.; Fallo, S.; Gontero, P.; Camussi, G.; et al. Extracellular vesicles from human liver stem cells inhibit renal cancer stem cell-derived tumor growth in vitro and in vivo. Int. J. Cancer 2020, 147, 1694-1706. [CrossRef]

54. Budgude, P.; Kale, V.; Vaidya, A. Mesenchymal stromal cell-derived extracellular vesicles as cell-free biologics for the ex vivo expansion of hematopoietic stem cells. Cell Biol. Int. 2020, 44, 1078-1102. [CrossRef]

55. Grange, C.; Bellucci, L.; Bussolati, B.; Ranghino, A. Potential Applications of Extracellular Vesicles in Solid Organ Transplantation. Cells 2020, 9, 369. [CrossRef] [PubMed]

56. Katsuda, T.; Tsuchiya, R.; Kosaka, N.; Yoshioka, Y.; Takagaki, K.; Oki, K.; Takeshita, F.; Sakai, Y.; Kuroda, M.; Ochiya, T. Human adipose tissue-derived mesenchymal stem cells secrete functional neprilysin-bound exosomes. Sci. Rep. 2013, 3, srep01197. [CrossRef]

57. Shao, M.; Xu, Q.; Wu, Z.; Chen, Y.; Shu, Y.; Cao, X.; Chen, M.; Zhang, B.; Zhou, Y.; Yao, R.; et al. Exosomes derived from human umbilical cord mesenchymal stem cells ameliorate IL-6-induced acute liver injury through miR-455-3p. Stem Cell Res. Ther. 2020, 11, 1-13. [CrossRef] [PubMed] 
58. Wong, K.L.; Zhang, S.; Wang, M.; Ren, X.; Afizah, H.; Lai, R.C.; Lim, S.K.; Lee, E.H.; Hui, J.H.P.; Toh, W.S. Intra-Articular Injections of Mesenchymal Stem Cell Exosomes and Hyaluronic Acid Improve Structural and Mechanical Properties of Repaired Cartilage in a Rabbit Model. Arthrosc. J. Arthrosc. Relat. Surg. 2020, 36, 2215-2228.e2. [CrossRef] [PubMed]

59. Yoon, Y.M.; Lee, J.H.; Song, K.-H.; Noh, H.; Lee, S.H. Melatonin-stimulated exosomes enhance the regenerative potential of chronic kidney disease-derived mesenchymal stem/stromal cells via cellular prion proteins. J. Pineal Res. 2020, 68, e12632. [CrossRef] [PubMed]

60. Katsuda, T.; Kosaka, N.; Takeshita, F.; Ochiya, T. The therapeutic potential of mesenchymal stem cell-derived extracellular vesicles. Proteom. 2013, 13, 1637-1653. [CrossRef]

61. Dilsiz, N. Role of exosomes and exosomal microRNAs in cancer. Futur. Sci. OA 2020, 6, FSO465. [CrossRef]

62. Maeda, Y.; Farina, N.H.; Matzelle, M.M.; Fanning, P.J.; Lian, J.B.; Gravallese, E.M. Synovium-Derived MicroRNAs Regulate Bone Pathways in Rheumatoid Arthritis. J. Bone Miner. Res. 2017, 32, 461-472. [CrossRef]

63. Ratajczak, J.; Miękus, K.; Kucia, M.; Zhang, J.; Reca, R.; Dvorak, P.; Ratajczak, M.Z. Embryonic stem cell-derived microvesicles reprogram hematopoietic progenitors: Evidence for horizontal transfer of mRNA and protein delivery. Leuk. 2006, 20, 847-856. [CrossRef]

64. Wang, L.; Wang, C.; Jia, X.; Yu, J. Circulating Exosomal miR-17 Inhibits the Induction of Regulatory T Cells via Suppressing TGFBR II Expression in Rheumatoid Arthritis. Cell. Physiol. Biochem. 2018, 50, 1754-1763. [CrossRef]

65. Wang, Y.; Zheng, F.; Gao, G.; Yan, S.; Zhang, L.; Wang, L.; Cai, X.; Wang, X.; Xu, D.; Wang, J. MiR-548a-3p regulates inflammatory response via TLR4/NF-kB signaling pathway in rheumatoid arthritis. J. Cell. Biochem. 2019, 120, 1133-1140. [CrossRef] [PubMed]

66. Xin, Y.; Yang, Z.; Fei, X.; Ke, L.; Juan, J.; Ting, F.; Xu, Z.; Gu, Z. THU0059 Plasma exosomal mir-92a are involved in the occurrence and development of bone destruction in ra patients by inhibiting apoptosis of fibroblast-like synoviocytes. Ann. Rheuma. Dis. 2018, 77, 254-255. [CrossRef]

67. Valadi, H.; Ekström, K.; Bossios, A.; Sjöstrand, M.; Lee, J.J.; Lötvall, J.O. Exosome-mediated transfer of mRNAs and microRNAs is a novel mechanism of genetic exchange between cells. Nat. Cell Biol. 2007, 9, 654-659. [CrossRef]

68. Choi, D.-S.; Kim, D.-K.; Kim, Y.-K.; Gho, Y.S. Proteomics, transcriptomics and lipidomics of exosomes and ectosomes. Proteomics 2013, 13, 1554-1571. [CrossRef] [PubMed]

69. Mathieu, M.; Martin-Jaular, L.; Lavieu, G.; Théry, C. Specificities of secretion and uptake of exosomes and other extracellular vesicles for cell-to-cell communication. Nat. Cell Biol. 2019, 21, 9-17. [CrossRef]

70. Skotland, T.; Hessvik, N.P.; Sandvig, K.; Llorente, A. Exosomal lipid composition and the role of ether lipids and phosphoinositides in exosome biology. J. Lipid Res. 2019, 60, 9-18. [CrossRef] [PubMed]

71. Skotland, T.; Sagini, K.; Sandvig, K.; Llorente, A. An emerging focus on lipids in extracellular vesicles. Adv. Drug Deliv. Rev. 2020, 159, 308-321. [CrossRef]

72. Skotland, T.; Sandvig, K.; Llorente, A. Lipids in exosomes: Current knowledge and the way forward. Prog. Lipid Res. 2017, 66, 30-41. [CrossRef]

73. Vidal, M.; Sainte-Marie, J.; Philippot, J.R.; Bienvenue, A. Asymmetric distribution of phospholipids in the membrane of vesicles released during in vitro maturation of guinea pig reticulocytes: Evidence precluding a role for ?aminophospholipid translocase? J. Cell. Physiol. 1989, 140, 455-462. [CrossRef]

74. Raposo, G.; Nijman, H.W.; Stoorvogel, W.; Liejendekker, R.; Harding, C.V.; Melief, C.J.; Geuze, H.J. B lymphocytes secrete antigen-presenting vesicles. J. Exp. Med. 1996, 183, 1161-1172. [CrossRef]

75. Hanson, P.I.; Cashikar, A. Multivesicular Body Morphogenesis. Annu. Rev. Cell Dev. Biol. 2012, 28, 337-362. [CrossRef] [PubMed]

76. Juan, T.; Fürthauer, M. Biogenesis and function of ESCRT-dependent extracellular vesicles. Semin. Cell Dev. Biol. 2018, 74, 66-77. [CrossRef] [PubMed]

77. Yáñez-Mó, M.; Siljander, P.R.-M.; Andreu, Z.; Zavec, A.B.; Borràs, F.E.; Buzas, E.I.; Buzas, K.; Casal, E.; Cappello, F.; Carvalho, J.; et al. Biological properties of extracellular vesicles and their physiological functions. J. Extracell. Vesicles 2015, 4, 27066. [CrossRef] [PubMed]

78. Colombo, M.; Moita, C.F.; van Niel, G.; Kowal, J.; Vigneron, J.; Benaroch, P.; Manel, N.; Moita, L.F.; Théry, C.; Raposo, G. Analysis of ESCRT functions in exosome biogenesis, composition and secretion highlights the heterogeneity of extracellular vesicles. J. Cell Sci. 2013, 126, 5553-5565. [CrossRef]

79. Farooqi, A.A.; Desai, N.N.; Qureshi, M.Z.; Nogueira-Librelotto, D.R.; Gasparri, M.L.; Bishayee, A.; Nabavi, S.M.; Curti, V.; Daglia, M. Exosome biogenesis, bioactivities and functions as new delivery systems of natural compounds. Biotechnol. Adv. 2018, 36, 328-334. [CrossRef]

80. Grant, B.D.; Donaldson, J.G. Pathways and mechanisms of endocytic recycling. Nat. Rev. Mol. Cell Biol. 2009, 10, 597-608. [CrossRef]

81. Kosaka, N.; Iguchi, H.; Yoshioka, Y.; Takeshita, F.; Matsuki, Y.; Ochiya, T. Secretory mechanisms and intercellular transfer of MicroRNAs in living cells. J. Biol. Chem. 2010, 285, 17442-17452. [CrossRef]

82. Monypenny, J.; Milewicz, H.; Flores-Borja, F.; Weitsman, G.; Cheung, A.; Chowdhury, R.; Burgoyne, T.; Arulappu, A.; Lawler, K.; Barber, P.R.; et al. ALIX Regulates Tumor-Mediated Immunosuppression by Controlling EGFR Activity and PD-L1 Presentation. Cell Rep. 2018, 24, 630-641. [CrossRef] [PubMed] 
83. Ostrowski, M.; Carmo, N.B.; Krumeich, S.; Fanget, I.; Raposo, G.; Savina, A.; Moita, C.F.; Schauer, K.; Hume, A.N.; Freitas, R.P.; et al. Rab27a and Rab27b control different steps of the exosome secretion pathway. Nat. Cell Biol. 2010, 12, 19-30. [CrossRef] [PubMed]

84. Peng, D.; Wang, H.; Li, L.; Ma, X.; Chen, Y.; Zhou, H.; Luo, Y.; Xiao, Y.; Liu, L. miR-34c-5p promotes eradication of acute myeloid leukemia stem cells by inducing senescence through selective RAB27B targeting to inhibit exosome shedding. Leukemia 2018, 32, 1180-1188. [CrossRef]

85. Poggio, M.; Hu, T.; Pai, C.-C.; Chu, B.; Belair, C.D.; Chang, A.; Montabana, E.; Lang, U.E.; Fu, Q.; Fong, L.; et al. Suppression of exosomal PD-L1 induces systemic anti-tumor immunity and memory. Cell 2019, 177, 414.e13-427.e13. [CrossRef]

86. Roucourt, B.; Meeussen, S.; Bao, J.; Zimmermann, P.; David, G. Heparanase activates the syndecan-syntenin-ALIX exosome pathway. Cell Res. 2015, 25, 412-428. [CrossRef] [PubMed]

87. Stenmark, H. Rab GTPases as coordinators of vesicle traffic. Nat. Rev. Mol. Cell Biol. 2009, 10, 513-525. [CrossRef]

88. Wenzel, E.M.; Schultz, S.W.; Schink, K.O.; Pedersen, N.M.; Nähse, V.; Carlson, A.; Brech, A.; Stenmark, H.; Raiborg, C. Concerted ESCRT and clathrin recruitment waves define the timing and morphology of intraluminal vesicle formation. Nat. Commun. 2018, 9, 1-18. [CrossRef] [PubMed]

89. Yang, L.; Peng, X.; Li, Y.; Zhang, X.; Ma, Y.; Wu, C.; Fan, Q.; Wei, S.; Li, H.; Liu, J. Long non-coding RNA HOTAIR promotes exosome secretion by regulating RAB35 and SNAP23 in hepatocellular carcinoma. Mol. Cancer 2019, 18, 1-12. [CrossRef]

90. Jahn, R.; Scheller, R.H. SNAREs-Engines for membrane fusion. Nat. Rev. Mol. Cell Biol. 2006, 7, 631-643. [CrossRef] [PubMed]

91. Hadacek, F. Low-molecular-weight metabolite systems chemistry. Front. Environ. Sci. 2015, 3, 12. [CrossRef]

92. Llorente, A.; Skotland, T.; Sylvänne, T.; Kauhanen, D.; Róg, T.; Orlowski, A.; Vattulainen, I.; Ekroos, K.; Sandvig, K. Molecular lipidomics of exosomes released by PC-3 prostate cancer cells. Biochim. et Biophys. Acta (BBA) Mol. Cell Biol. Lipids 2013, 1831, 1302-1309. [CrossRef]

93. Mittelbrunn, M.; Gutierrez-Vazquez, C.; Villarroya-Beltri, C.; González, S.; Sanchez-Cabo, F.; González, M.Á.; Bernad, A.; Sánchez-Madrid, F. Unidirectional transfer of microRNA-loaded exosomes from T cells to antigen-presenting cells. Nat. Commun. 2011, 2, 282. [CrossRef] [PubMed]

94. Montecalvo, A.; Larregina, A.T.; Shufesky, W.J.; Beer Stolz, D.; Sullivan, M.L.G.; Karlsson, J.M.; Baty, C.J.; Gibson, G.A.; Erdos, G.; Wang, Z.; et al. Mechanism of transfer of functional microRNAs between mouse dendritic cells via exosomes. Blood 2012, 119, 756-766. [CrossRef]

95. Nolte-'t Hoen, E.N.; Buermans, H.P.J.; Waasdorp, M.; Stoorvogel, W.; Wauben, M.H.M.; 't Hoen Hoen, P.A. Deep sequencing of RNA from immune cell-derived vesicles uncovers the selective incorporation of small non-coding RNA biotypes with potential regulatory functions. Nucleic Acids Res. 2012, 40, 9272-9285. [CrossRef]

96. Raimondo, F.; Morosi, L.; Chinello, C.; Magni, F.; Pitto, M. Advances in membranous vesicle and exosome proteomics improving biological understanding and biomarker discovery. Proteomics 2011, 11, 709-720. [CrossRef] [PubMed]

97. Boorn, J.G.V.D.; Daßler, J.; Coch, C.; Schlee, M.; Hartmann, G. Exosomes as nucleic acid nanocarriers. Adv. Drug Deliv. Rev. 2013, 65, 331-335. [CrossRef] [PubMed]

98. Zebrowska, A.; Skowronek, A.; Wojakowska, A.; Widlak, P.; Pietrowska, M. Metabolome of Exosomes: Focus on Vesicles Released by Cancer Cells and Present in Human Body Fluids. Int. J. Mol. Sci. 2019, 20, 3461. [CrossRef] [PubMed]

99. Keerthikumar, S.; Chisanga, D.; Ariyaratne, D.; Al Saffar, H.; Anand, S.; Zhao, K.; Samuel, M.; Pathan, M.; Jois, M.; Chilamkurti, N.; et al. ExoCarta: A Web-Based Compendium of Exosomal Cargo. J. Mol. Biol. 2016, 428, 688-692. [CrossRef]

100. Mathivanan, S.; Fahner, C.J.; Reid, G.; Simpson, R.J. ExoCarta 2012: Database of exosomal proteins, RNA and lipids. Nucleic Acids Res. 2011, 40, D1241-D1244. [CrossRef]

101. Mathivanan, S.; Simpson, R.J. ExoCarta: A compendium of exosomal proteins and RNA. Proteomics 2009, 9, 4997-5000. [CrossRef]

102. Simpson, R.J.; Kalra, H.; Mathivanan, S. ExoCarta as a resource for exosomal research. J. Extracell. Vesicles 2012, 1, 10-3402. [CrossRef]

103. Blanchard, N.; Lankar, D.; Faure, F.; Regnault, A.; Dumont, C.; Raposo, G.; Hivroz, C. TCR Activation of Human T Cells Induces the Production of Exosomes Bearing the TCR/CD3/ C Complex. J. Immunol. 2002, 168, 3235-3241. [CrossRef] [PubMed]

104. Kleijmeer, M.J.; Escola, J.M.; UytdeHaag, F.G.; Jakobson, E.; Griffith, J.M.; Osterhaus, A.D.; Stoorvogel, W.; Melief, C.J.; Rabouille, C.; Geuze, H.J. Antigen Loading of MHC Class I Molecules in the Endocytic Tract. Traffic 2001, 2, 124-137. [CrossRef] [PubMed]

105. Van Niel, G.; Raposo, G.; Candalh, C.; Boussac, M.; Hershberg, R.; Cerf-Bensussan, N.; Heyman, M. Intestinal epithelial cells secrete exosome-like vesicles. Gastroenterology 2001, 121, 337-349. [CrossRef] [PubMed]

106. Wolfers, J.; Lozier, A.; Raposo, G.; Regnault, A.; Théry, C.; Masurier, C.; Flament, C.; Pouzieux, S.; Faure, F.; Tursz, T.; et al. Tumor-derived exosomes are a source of shared tumor rejection antigens for CTL cross-priming. Nat. Med. 2001, 7, $297-303$. [CrossRef] [PubMed]

107. Zitvogel, L.; Regnault, A.; Lozier, A.; Wolfers, J.; Flament, C.; Tenza, D.; Ricciardi-Castagnoli, P.; Raposo, G.; Amigorena, S. Eradication of established murine tumors using a novel cell-free vaccine: Dendritic cell derived exosomes. Nat. Med. 1998, 4, 594-600. [CrossRef] [PubMed]

108. Raposo, G.; Tenza, D.; Mecheri, S.; Peronet, R.; Bonnerot, C.; Desaymard, C. Accumulation of Major Histocompatibility Complex Class II Molecules in Mast Cell Secretory Granules and Their Release upon Degranulation. Mol. Biol. Cell 1997, 8, $2631-2645$. [CrossRef] [PubMed] 
109. Liu, H.; Chen, L.; Peng, Y.; Yu, S.; Liu, J.; Wu, L.; Zhang, L.; Wu, Q.; Chang, X.; Yu, X.; et al. Dendritic cells loaded with tumor derived exosomes for cancer immunotherapy. Oncotarget 2017, 9, 2887-2894. [CrossRef]

110. Rieu, S.; Geminard, C.; Rabesandratana, H.; Sainte-Marie, J.; Vidal, M. Exosomes released during reticulocyte maturation bind to fibronectin via integrin $\alpha 4 \beta 1$. JBIC J. Biol. Inorg. Chem. 2000, 267, 583-590. [CrossRef] [PubMed]

111. Théry, C.; Regnault, A.; Garin, J.; Wolfers, J.; Zitvogel, L.; Ricciardi-Castagnoli, P.; Raposo, G.; Amigorena, S. Molecular Characterization of Dendritic Cell-Derived Exosomes. J. Cell Biol. 1999, 147, 599-610. [CrossRef] [PubMed]

112. Skokos, D.; Le Panse, S.; Villa, I.; Rousselle, J.-C.; Peronet, R.; David, B.; Namane, A.; Mécheri, S. Mast Cell-Dependent B and T Lymphocyte Activation Is Mediated by the Secretion of Immunologically Active Exosomes. J. Immunol. 2001, 166, 868-876. [CrossRef] [PubMed]

113. Clayton, A.; Court, J.; Navabi, H.; Adams, M.; Mason, M.D.; A Hobot, J.; Newman, G.R.; Jasani, B. Analysis of antigen presenting cell derived exosomes, based on immuno-magnetic isolation and flow cytometry. J. Immunol. Methods 2001, 247, 163-174. [CrossRef]

114. Escola, J.-M.; Kleijmeer, M.J.; Stoorvogel, W.; Griffith, J.M.; Yoshie, O.; Geuze, H.J. Selective Enrichment of Tetraspan Proteins on the Internal Vesicles of Multivesicular Endosomes and on Exosomes Secreted by Human B-lymphocytes. J. Biol. Chem. 1998, 273, 20121-20127. [CrossRef] [PubMed]

115. Heijnen, H.F.; Schiel, A.E.; Fijnheer, R.; Geuze, H.J.; Sixma, J.J. Activated Platelets Release Two Types of Membrane Vesicles: Microvesicles by Surface Shedding and Exosomes Derived From Exocytosis of Multivesicular Bodies and $\alpha$-Granules. Blood 1999, 94, 3791-3799. [CrossRef] [PubMed]

116. Vincent-Schneider, H.; Stumptner-Cuvelette, P.; Lankar, D.; Pain, S.; Raposo, G.; Benaroch, P.; Bonnerot, C. Exosomes bearing HLA-DR1 molecules need dendritic cells to efficiently stimulate specific T cells. Int. Immunol. 2002, 14, 713-722. [CrossRef]

117. Borges, T.J.; Wieten, L.; Van Herwijnen, M.J.C.; Broere, F.; Van Der Zee, R.; Bonorino, C.; Van Eden, W. The anti-inflammatory mechanisms of Hsp70. Front. Immunol. 2012, 3, 95. [CrossRef]

118. Chanteloup, G.; Cordonnier, M.; Isambert, N.; Bertaut, A.; Hervieu, A.; Hennequin, A.; Luu, M.; Zanetta, S.; Coudert, B.; Bengrine, L.; et al. Monitoring HSP70 exosomes in cancer patients' follow up: A clinical prospective pilot study. J. Extracell. Vesicles 2020, 9 , 1766192. [CrossRef] [PubMed]

119. Lancaster, G.I.; Febbraio, M.A. Exosome-dependent Trafficking of HSP70. J. Biol. Chem. 2005, 280, 23349-23355. [CrossRef] [PubMed]

120. Wyciszkiewicz, A.; Kalinowska-Łyszczarz, A.; Nowakowski, B.; Kaźmierczak, K.; Osztynowicz, K.; Michalak, S. Expression of small heat shock proteins in exosomes from patients with gynecologic cancers. Sci. Rep. 2019, 9, 1-9. [CrossRef]

121. Théry, C.; Boussac, M.; Véron, P.; Ricciardi-Castagnoli, P.; Raposo, G.; Garin, J.; Amigorena, S. Proteomic Analysis of Dendritic Cell-Derived Exosomes: A Secreted Subcellular Compartment Distinct from Apoptotic Vesicles. J. Immunol. 2001, 166, 7309-7318. [CrossRef] [PubMed]

122. Aoki, N.; Jin-No, S.; Nakagawa, Y.; Asai, N.; Arakawa, E.; Tamura, N.; Tamura, T.; Matsuda, T. Identification and Characterization of Microvesicles Secreted by 3T3-L1 Adipocytes: Redox- and Hormone-Dependent Induction of Milk Fat Globule-Epidermal Growth Factor 8-Associated Microvesicles. Endocrinol. 2007, 148, 3850-3862. [CrossRef]

123. Müller, G. Control of lipid storage and cell size between adipocytes by vesicle-associated glycosylphosphatidylinositol-anchored proteins. Arch. Physiol. Biochem. 2010, 117, 23-43. [CrossRef]

124. Müller, G.; Wied, S.; Dearey, E.-A.; Wetekam, E.-M.; Biemer-Daub, G. Lipid Storage in Large and Small Rat Adipocytes by Vesicle-Associated Glycosylphosphatidylinositol-Anchored Proteins. Chem. Biol. Pteridines Folates 2010, 52, 27-34. [CrossRef]

125. Ogawa, R.; Tanaka, C.; Sato, M.; Nagasaki, H.; Sugimura, K.; Okumura, K.; Nakagawa, Y.; Aoki, N. Adipocyte-derived microvesicles contain RNA that is transported into macrophages and might be secreted into blood circulation. Biochem. Biophys. Res. Commun. 2010, 398, 723-729. [CrossRef] [PubMed]

126. Subra, C.; Laulagnier, K.; Perret, B.; Record, M. Exosome lipidomics unravels lipid sorting at the level of multivesicular bodies. Biochimie 2007, 89, 205-212. [CrossRef] [PubMed]

127. Laulagnier, K.; Motta, C.; Hamdi, S.; Roy, S.; Fauvelle, F.; Pageaux, J.-F.; Kobayashi, T.; Salles, J.-P.; Perret, B.; Bonnerot, C.; et al. Mast cell- and dendritic cell-derived exosomes display a specific lipid composition and an unual membrane organization. Biochem. J. 2004, 380, 161-171. [CrossRef] [PubMed]

128. Brzozowski, J.S.; Jankowski, H.; Bond, D.R.; McCague, S.B.; Munro, B.R.; Predebon, M.J.; Scarlett, C.J.; Skelding, K.A.; Weidenhofer, J. Lipidomic profiling of extracellular vesicles derived from prostate and prostate cancer cell lines. Lipids Heal. Dis. 2018, 17, 1-12. [CrossRef]

129. Trajkovic, K.; Hsu, C.; Chiantia, S.; Rajendran, L.; Wenzel, D.; Wieland, F.; Schwille, P.; Brugger, B.; Simons, M. Ceramide Triggers Budding of Exosome Vesicles into Multivesicular Endosomes. Science 2008, 319, 1244-1247. [CrossRef]

130. Brouwers, J.F.; Aalberts, M.; Jansen, J.W.A.; Van Niel, G.; Wauben, M.; Stout, T.A.E.; Helms, J.B.; Stoorvogel, W. Distinct lipid compositions of two types of human prostasomes. Proteomics 2013, 13, 1660-1666. [CrossRef] [PubMed]

131. Skotland, T.; Ekroos, K.; Kauhanen, D.; Simolin, H.; Seierstad, T.; Berge, V.; Sandvig, K.; Llorente, A. Molecular lipid species in urinary exosomes as potential prostate cancer biomarkers. Eur. J. Cancer 2017, 70, 122-132. [CrossRef]

132. Simbari, F.; McCaskill, J.; Coakley, G.; Millar, M.; Maizels, R.M.; Fabriás, G.; Casas, J.; Buck, A.H. Plasmalogen enrichment in exosomes secreted by a nematode parasite versus those derived from its mouse host: Implications for exosome stability and biology. J. Extracell. Vesicles 2016, 5, 30741. [CrossRef] [PubMed] 
133. Pienimaeki-Roemer, A.; Kuhlmann, K.; Böttcher, A.; Konovalova, T.; Black, A.; Orsó, E.; Liebisch, G.; Ahrens, M.; Eisenacher, M.; Meyer, H.E.; et al. Lipidomic and proteomic characterization of platelet extracellular vesicle subfractions from senescent platelets. Transfusion 2015, 55, 507-521. [CrossRef]

134. Durcin, M.; Fleury, A.; Taillebois, E.; Hilairet, G.; Krupova, Z.; Henry, C.; Truchet, S.; Trötzmüller, M.; Köfeler, H.; Mabilleau, G.; et al. Characterisation of adipocyte-derived extracellular vesicle subtypes identifies distinct protein and lipid signatures for large and small extracellular vesicles. J. Extracell. Vesicles 2017, 6, 1305677. [CrossRef]

135. Zhang, L.; Li, H.; Yuan, M.; Li, D.; Sun, C.; Wang, G. Serum Exosomal MicroRNAs as Potential Circulating Biomarkers for Endometriosis. Dis. Markers 2020, 2020, 2456340. [CrossRef]

136. Zhao, Y.; Gan, Y.; Xu, G.; Yin, G.; Liu, D. MSCs-Derived Exosomes Attenuate Acute Brain Injury and Inhibit Microglial Inflammation by Reversing CysLT2R-ERK1/2 Mediated Microglia M1 Polarization. Neurochem. Res. 2020, 45, 1180-1190. [CrossRef]

137. Leidal, A.M.; Debnath, J. Unraveling the mechanisms that specify molecules for secretion in extracellular vesicles. Methods 2020, 177, 15-26. [CrossRef] [PubMed]

138. Zhou, M.; Tan, K.S.; Guan, W.-J.; Jiang, L.-J.; Deng, J.; Gao, W.-X.; Lee, Y.M.; Xu, Z.-F.; Luo, X.; Liu, C.; et al. Proteomics profiling of epithelium-derived exosomes from nasal polyps revealed signaling functions affecting cellular proliferation. Respir. Med. 2020, 162, 105871. [CrossRef]

139. Peterka, O.; Jirásko, R.; Chocholoušková, M.; Kuchař, L.; Wolrab, D.; Hájek, R.; Vrána, D.; Strouhal, O.; Melichar, B.; Holčapek, M. Lipidomic characterization of exosomes isolated from human plasma using various mass spectrometry techniques. Biochim. et Biophys. Acta (BBA) Mol. Cell Biol. Lipids 2020, 1865, 158634. [CrossRef] [PubMed]

140. Tiruvayipati, S.; Wolfgeher, D.; Yue, M.; Duan, F.; Andrade, J.; Jiang, H.; Schuger, L. Variability in protein cargo detection in technical and biological replicates of exosome-enriched extracellular vesicles. PLoS ONE 2020, 15, e0228871. [CrossRef] [PubMed]

141. Breglio, A.M.; May, L.A.; Barzik, M.; Welsh, N.C.; Francis, S.P.; Costain, T.Q.; Wang, L.; Anderson, D.E.; Petralia, R.S.; Wang, Y.-X.; et al. Exosomes mediate sensory hair cell protection in the inner ear. J. Clin. Investig. 2020, 130, 2657-2672. [CrossRef] [PubMed]

142. Jones, L.B.; Kumar, S.; Curry, A.J.; Price, J.S.; Krendelchtchikov, A.; Crenshaw, B.J.; Bell, C.R.; Williams, S.D.; Tolliver, T.A.; Saldanha, S.N.; et al. Alcohol Exposure Impacts the Composition of HeLa-Derived Extracellular Vesicles. Biomedicines $2019,7,78$. [CrossRef] [PubMed]

143. Srivastava, P. INTERACTION OFHEATSHOCKPROTEINS WITHPEPTIDES ANDANTIGENPRESENTINGCELLS: Chaperoning of the Innate and Adaptive Immune Responses. Annu. Rev. Immunol. 2002, 20, 395-425. [CrossRef]

144. Zeng, F.; Morelli, A.E. Extracellular vesicle-mediated MHC cross-dressing in immune homeostasis, transplantation, infectious diseases, and cancer. Semin. Immunopathol. 2018, 40, 477-490. [CrossRef]

145. Stubbs, J.D.; Lekutis, C.; Singer, K.L.; Bui, A.; Yuzuki, D.; Srinivasan, U.; Parry, G. cDNA cloning of a mouse mammary epithelial cell surface protein reveals the existence of epidermal growth factor-like domains linked to factor VIII-like sequences. Proc. Natl. Acad. Sci. USA 1990, 87, 8417-8421. [CrossRef] [PubMed]

146. Orozco, A.F.; Lewis, D.E. Flow cytometric analysis of circulating microparticles in plasma. Cytom. Part A 2010, 77, 502-514. [CrossRef]

147. Chu, Z.; Witte, D.P.; Qi, X. Saposin C-LBPA interaction in late-endosomes/lysosomes. Exp. Cell Res. 2005, 303, 300-307. [CrossRef]

148. Minciacchi, V.R.; Freeman, M.R.; Di Vizio, D. Extracellular Vesicles in Cancer: Exosomes, Microvesicles and the Emerging Role of Large Oncosomes. Semin. Cell Dev. Biol. 2015, 40, 41-51. [CrossRef]

149. Subra, C.; Grand, D.; Laulagnier, K.; Stella, A.; Lambeau, G.; Paillasse, M.; De Medina, P.; Monsarrat, B.; Perret, B.; Silvente-Poirot, S.; et al. Exosomes account for vesicle-mediated transcellular transport of activatable phospholipases and prostaglandins. J. Lipid Res. 2010, 51, 2105-2120. [CrossRef]

150. Fitzner, D.; Schnaars, M.; van Rossum, D.; Krishnamoorthy, G.; Dibaj, P.; Bakhti, M.; Regen, T.; Hanisch, U.-K.; Simons, M. Selective transfer of exosomes from oligodendrocytes to microglia by macropinocytosis. J. Cell Sci. 2011, 124, 447-458. [CrossRef]

151. Lydic, T.A.; Townsend, S.; Adda, C.G.; Collins, C.; Mathivanan, S.; Reid, G.E. Rapid and comprehensive "shotgun" lipidome profiling of colorectal cancer cell derived exosomes. Methods 2015, 87, 83-95. [CrossRef] [PubMed]

152. Haraszti, R.A.; Didiot, M.-C.; Sapp, E.; Leszyk, J.; Shaffer, S.A.; Rockwell, H.E.; Gao, F.; Narain, N.R.; DiFiglia, M.; Kiebish, M.A.; et al. High-resolution proteomic and lipidomic analysis of exosomes and microvesicles from different cell sources. J. Extracell. Vesicles 2016, 5, 32570. [CrossRef] [PubMed]

153. Abels, E.R.; Breakefield, X.O. Introduction to Extracellular Vesicles: Biogenesis, RNA Cargo Selection, Content, Release, and Uptake. Cell. Mol. Neurobiol. 2016, 36, 301-312. [CrossRef]

154. Chen, T.S.; Lai, R.C.; Lee, M.M.; Choo, A.B.H.; Lee, C.N.; Lim, S.K. Mesenchymal stem cell secretes microparticles enriched in pre-microRNAs. Nucleic Acids Res. 2009, 38, 215-224. [CrossRef] [PubMed]

155. Tan, S.S.; Chen, T.S.; Tan, K.H.; Lim, S.K. An Overview of the Proteomic and miRNA Cargo in MSC-Derived Exosomes. Mesenchymal Stem Cell Derived Exosomes 2015, 21-36.

156. Chen, T.S.; Lim, S.K. Measurement of Precursor miRNA in Exosomes from Human ESC-Derived Mesenchymal Stem Cells. Methods Mol. Biol. 2013, 1024, 69-86. [CrossRef]

157. Smalheiser, N.R. Exosomal transfer of proteins and RNAs at synapses in the nervous system. Biol. Direct 2007, 2, 35. [CrossRef] [PubMed]

158. Banerjee, J.; Sen, C.K. microRNA and Wound Healing. Adv. Exp. Med. Biol. 2015, 888, 291-305. [CrossRef] 
159. Liu, T.; Zhang, Q.; Zhang, J.; Li, C.; Miao, Y.-R.; Lei, Q.; Li, Q.; Guo, A.-Y. EVmiRNA: A database of miRNA profiling in extracellular vesicles. Nucleic Acids Res. 2019, 47, D89-D93. [CrossRef]

160. Vallabhaneni, K.C.; Penfornis, P.; Dhule, S.; Guillonneau, F.; Adams, K.V.; Mo, Y.Y.; Xu, R.; Liu, Y.; Watabe, K.; Vemuri, M.C.; et al. Extracellular vesicles from bone marrow mesenchymal stem/stromal cells transport tumor regulatory microRNA, proteins, and metabolites. Oncotarget 2015, 6, 4953-4967. [CrossRef]

161. Lee, J.-K.; Park, S.-R.; Jung, B.-K.; Jeon, Y.-K.; Lee, Y.-S.; Kim, M.-K.; Kim, Y.-G.; Jang, J.-Y.; Kim, C.-W. Exosomes Derived from Mesenchymal Stem Cells Suppress Angiogenesis by Down-Regulating VEGF Expression in Breast Cancer Cells. PLoS ONE 2013, 8, e84256. [CrossRef] [PubMed]

162. Singla, D.K. Stem cells and exosomes in cardiac repair. Curr. Opin. Pharmacol. 2016, 27, 19-23. [CrossRef] [PubMed]

163. Shao, L.; Zhang, Y.; Lan, B.; Wang, J.; Zhang, Z.; Zhang, L.; Xiao, P.; Meng, Q.; Geng, Y.-J.; Yu, X.-Y.; et al. MiRNA-Sequence Indicates That Mesenchymal Stem Cells and Exosomes Have Similar Mechanism to Enhance Cardiac Repair. BioMed Res. Int. 2017, 2017, 4150705. [CrossRef] [PubMed]

164. Zhao, B.; Li, X.; Shi, X.; Shi, X.; Zhang, W.; Wu, G.; Wang, X.; Su, L.; Hu, D. Exosomal MicroRNAs Derived from Human Amniotic Epithelial Cells Accelerate Wound Healing by Promoting the Proliferation and Migration of Fibroblasts. Stem Cells Int. 2018, 2018, 5420463. [CrossRef]

165. Gao, S.; Chen, T.; Hao, Y.; Zhang, F.; Tang, X.; Wang, D.; Wei, Z.; Qi, J. Exosomal miR-135a derived from human amnion mesenchymal stem cells promotes cutaneous wound healing in rats and fibroblast migration by directly inhibiting LATS2 expression. Stem Cell Res. Ther. 2020, 11, 1-11. [CrossRef] [PubMed]

166. Lvł, X.; Lił, Y.; Lił, H.; Zhou, L.; Wang, B.; Zhi, Z.; Tang, W. Molecular function predictions and diagnostic value analysis of plasma exosomal miRNAs in Hirschsprung's disease. Epigenomics 2020, 12, 409-422. [CrossRef]

167. Lv, Q.; Deng, J.; Chen, Y.; Wang, Y.; Liu, B.; Liu, J. Engineered Human Adipose Stem-Cell-Derived Exosomes Loaded with miR-21-5p to Promote Diabetic Cutaneous Wound Healing. Mol. Pharm. 2020, 17, 1723-1733. [CrossRef]

168. Li, P.; Kaslan, M.; Lee, S.H.; Yao, J.; Gao, Z. Progress in Exosome Isolation Techniques. Theranostics 2017, 7, 789-804. [CrossRef]

169. Yang, F.; Liao, X.; Tian, Y.; Li, G. Exosome separation using microfluidic systems: Size-based, immunoaffinity-based and dynamic methodologies. Biotechnol. J. 2017, 12. [CrossRef] [PubMed]

170. Livshits, M.A.; Khomyakova, E.; Evtushenko, E.; Lazarev, V.N.; Kulemin, N.; Semina, S.E.; Generozov, E.; Govorun, V.M. Isolation of exosomes by differential centrifugation: Theoretical analysis of a commonly used protocol. Sci. Rep. 2015, 5, 17319. [CrossRef] [PubMed]

171. Lobb, R.; Becker, M.; Wen, S.W.; Wong, C.S.F.; Wiegmans, A.P.; Leimgruber, A.; Möller, A. Optimized exosome isolation protocol for cell culture supernatant and human plasma. J. Extracell. Vesicles 2015, 4, 27031. [CrossRef] [PubMed]

172. Cvjetkovic, A.; Lötvall, J.; Lässer, C. The influence of rotor type and centrifugation time on the yield and purity of extracellular vesicles. J. Extracell. Vesicles 2014, 3. [CrossRef] [PubMed]

173. Street, J.M.; Koritzinsky, E.H.; Glispie, D.M.; Yuen, P.S.T. Urine Exosome Isolation and Characterization. Methods Mol. Biol. 2017, 1641, 413-423. [PubMed]

174. Yamashita, T.; Takahashi, Y.; Nishikawa, M.; Takakura, Y. Effect of exosome isolation methods on physicochemical properties of exosomes and clearance of exosomes from the blood circulation. Eur. J. Pharm. Biopharm. 2016, 98, 1-8. [CrossRef]

175. Hong, C.-S.; Funk, S.; Muller, L.; Boyiadzis, M.; Whiteside, T.L. Isolation of biologically active and morphologically intact exosomes from plasma of patients with cancer. J. Extracell. Vesicles 2016, 5, 29289. [CrossRef]

176. Quintana, J.F.; Makepeace, B.L.; A Babayan, S.; Ivens, A.; Pfarr, K.M.; Blaxter, M.; Debrah, A.; Wanji, S.; Ngangyung, H.F.; Bah, G.S.; et al. Extracellular Onchocerca-derived small RNAs in host nodules and blood. Parasites Vectors 2015, 8, 58. [CrossRef]

177. Zeringer, E.; Barta, T.; Li, M.; Vlassov, A.V. Strategies for Isolation of Exosomes. Cold Spring Harb. Protoc. 2015, $2015,319-323$. [CrossRef]

178. Bhattacharjee, C.; Singh, M. Studies on the applicability of artificial neural network (ANN) in continuous stirred ultrafiltration. Chem. Eng. Technol. 2002, 25, 1181-1192. [CrossRef]

179. Yu, L.-L.; Zhu, J.; Liu, J.-X.; Jiang, F.; Ni, W.-K.; Qu, L.-S.; Ni, R.-Z.; Lu, C.-H.; Xiao, M.-B. A Comparison of Traditional and Novel Methods for the Separation of Exosomes from Human Samples. BioMed Res. Int. 2018, 2018, 3634563. [CrossRef]

180. Böing, A.N.; van der Pol, E.; Grootemaat, A.E.; Coumans, F.A.W.; Sturk, A.; Nieuwland, R. Single-step isolation of extracellular vesicles by size-exclusion chromatography. J. Extracell. Vesicles 2014, 3. [CrossRef]

181. Foers, A.D.; Chatfield, S.; Dagley, L.F.; Scicluna, B.J.; Webb, A.I.; Cheng, L.; Hill, A.F.; Wicks, I.P.; Pang, K.C. Enrichment of extracellular vesicles from human synovial fluid using size exclusion chromatography. J. Extracell. Vesicles 2018, 7, 1490145. [CrossRef]

182. Feng, Y.; Huang, W.; Wani, M.; Yu, X.; Ashraf, M. Ischemic Preconditioning Potentiates the Protective Effect of Stem Cells through Secretion of Exosomes by Targeting Mecp2 via miR-22. PLoS ONE 2014, 9, e88685. [CrossRef]

183. Dhondt, B.; Geeurickx, E.; Tulkens, J.; Van Deun, J.; Vergauwen, G.; Lippens, L.; Miinalainen, I.; Rappu, P.; Heino, J.; Ost, P.; et al. Unravelling the proteomic landscape of extracellular vesicles in prostate cancer by density-based fractionation of urine. $J$. Extracell. Vesicles 2020, 9, 1736935. [CrossRef]

184. Rood, I.M.; Deegens, J.K.; Merchant, M.L.; Tamboer, W.P.; Wilkey, D.W.; Wetzels, J.F.; Klein, J.B. Comparison of three methods for isolation of urinary microvesicles to identify biomarkers of nephrotic syndrome. Kidney Int. 2010, 78, 810-816. [CrossRef] [PubMed] 
185. La Shu, S.; Yang, Y.; Allen, C.L.; Hurley, E.; Tung, K.H.; Minderman, H.; Wu, Y.; Ernstoff, M.S. Purity and yield of melanoma exosomes are dependent on isolation method. J. Extracell. Vesicles 2020, 9, 1692401. [CrossRef]

186. Xu, L.; Ihara, K.-I.; Yoshimura, S.; Konno, D.; Tachibana, A.; Nakanishi, T.; Tachibana, T. Generation of the Rat Monoclonal Antibody Against the Extracellular Domain of Human CD63 by DNA Immunization. Monoclon. Antibodies Immunodiagn. Immunother. 2020, 39, 74-76. [CrossRef]

187. Xu, Y.; Shen, L.; Li, F.; Yang, J.; Wan, X.; Ouyang, M. microRNA-16-5p-containing exosomes derived from bone marrow-derived mesenchymal stem cells inhibit proliferation, migration, and invasion, while promoting apoptosis of colorectal cancer cells by downregulating ITGA2. J. Cell. Physiol. 2019, 234, 21380-21394. [CrossRef] [PubMed]

188. Zarovni, N.; Corrado, A.; Guazzi, P.; Zocco, D.; Lari, E.; Radano, G.; Muhhina, J.; Fondelli, C.; Gavrilova, J.; Chiesi, A. Integrated isolation and quantitative analysis of exosome shuttled proteins and nucleic acids using immunocapture approaches. Methods 2015, 87, 46-58. [CrossRef]

189. Karttunen, J.; Heiskanen, M.; Navarro-Ferrandis, V.; Das Gupta, S.; Lipponen, A.; Puhakka, N.; Rilla, K.; Koistinen, A.; Pitkänen, A. Precipitation-based extracellular vesicle isolation from rat plasma co-precipitate vesicle-free microRNAs. J. Extracell. Vesicles 2019, 8, 1555410. [CrossRef] [PubMed]

190. Ludwig, A.-K.; De Miroschedji, K.; Doeppner, T.R.; Börger, V.; Ruesing, J.; Rebmann, V.; Durst, S.; Jansen, S.; Bremer, M.; Behrmann, E.; et al. Precipitation with polyethylene glycol followed by washing and pelleting by ultracentrifugation enriches extracellular vesicles from tissue culture supernatants in small and large scales. J. Extracell. Vesicles 2018, 7, 1528109. [CrossRef] [PubMed]

191. Doyle, L.M.; Wang, M.Z. Overview of Extracellular Vesicles, Their Origin, Composition, Purpose, and Methods for Exosome Isolation and Analysis. Cells 2019, 8, 727. [CrossRef]

192. Van Deun, J.; Mestdagh, P.; Sormunen, R.; Cocquyt, V.; Vermaelen, K.; Vandesompele, J.; Bracke, M.; De Wever, O.; Hendrix, A. The impact of disparate isolation methods for extracellular vesicles on downstream RNA profiling. J. Extracell. Vesicles 2014, 3, 10-3402. [CrossRef]

193. Wang, C.; Chang, I.; Hou, P.; Tai, Y.; Li, W.; Hsu, P.; Wu, S.; Chiu, W.; Li, C.; Shan, Y.; et al. DUSP2 regulates extracellular vesicle-VEGF-C secretion and pancreatic cancer early dissemination. J. Extracell. Vesicles 2020, 9, 1746529. [CrossRef]

194. Guo, S.-C.; Tao, S.-C.; Dawn, H. Microfluidics-based on-a-chip systems for isolating and analysing extracellular vesicles. J. Extracell. Vesicles 2018, 7, 1508271. [CrossRef] [PubMed]

195. Iliescu, F.S.; Vrtačnik, D.; Neuzil, P.; Iliescu, C. Microfluidic Technology for Clinical Applications of Exosomes. Micromachines 2019, 10, 392. [CrossRef] [PubMed]

196. Jia, Y.; Ni, Z.; Sun, H.; Wang, C. Microfluidic Approaches Toward the Isolation and Detection of Exosome Nanovesicles. IEEE Access 2019, 7, 45080-45098. [CrossRef]

197. Dehdashtian, A.; Stringer, T.P.; Warren, A.J.; Mu, E.W.; Amirlak, B.; Shahabi, L. Anatomy and Physiology of the Skin. Cancer Treat. Res. 2018, 15-26.

198. Gantwerker, E.A.; Hom, D.B. Skin: Histology and Physiology of Wound Healing. Facial Plast. Surg. Clin. N. Am. 2011, 19, 441-453. [CrossRef] [PubMed]

199. Kolarsick, P.A.J.; Kolarsick, M.A.; Goodwin, C. Anatomy and Physiology of the Skin. J. Dermatol. Nurses' Assoc. $2011,3,203-213$. [CrossRef]

200. Dinh, T.; Braunagel, S.; Rosenblum, B.I. Growth Factors in Wound Healing. Clin. Podiatr. Med. Surg. 2015, 32, 109-119. [CrossRef]

201. Li, M.; Wang, T.; Tian, H.; Wei, G.; Zhao, L.; Shi, Y. Macrophage-derived exosomes accelerate wound healing through their anti-inflammation effects in a diabetic rat model. Artif. Cells Nanomed. Biotechnol. 2019, 47, 3793-3803. [CrossRef]

202. Lo Sicco, C.; Reverberi, D.; Balbi, C.; Ulivi, V.; Principi, E.; Pascucci, L.; Becherini, P.; Bosco, M.C.; Varesio, L.; Franzin, C.; et al Mesenchymal Stem Cell-Derived Extracellular Vesicles as Mediators of Anti-Inflammatory Effects: Endorsement of Macrophage Polarization. Stem Cells Transl. Med. 2017, 6, 1018-1028. [CrossRef] [PubMed]

203. Monaco, J.L.; Lawrence, W.T. Acute wound healing. Clin. Plast. Surg. 2003, 30, 1-12. [CrossRef]

204. Osada-Oka, M.; Shiota, M.; Izumi, Y.; Nishiyama, M.; Tanaka, M.; Yamaguchi, T.; Sakurai, E.; Miura, K.; Iwao, H. Macrophagederived exosomes induce inflammatory factors in endothelial cells under hypertensive conditions. Hypertens. Res. 2017, 40, 353-360. [CrossRef]

205. Bannon, P.; Wood, S.; Restivo, T.; Campbell, L.; Hardman, M.J.; Mace, K.A. Diabetes induces stable intrinsic changes to myeloid cells that contribute to chronic inflammation during wound healing in mice. Dis. Model. Mech. 2013, 6, 1434-1447. [CrossRef]

206. Hart, J. Inflammation 2: Its role in the healing of chronic wounds. J. Wound Care 2002, 11, 245-249. [CrossRef] [PubMed]

207. Liu, Y.-C.; Zou, X.-B.; Chai, Y.-F.; Yao, Y.-M. Macrophage Polarization in Inflammatory Diseases. Int. J. Biol. Sci. 2014, 10, 520-529. [CrossRef]

208. Robson, M.C.; Steed, D.L.; Franz, M.G. Wound healing: Biologic features and approaches to maximize healing trajectories. Curr. Probl. Surg. 2001, 38, 72-140. [CrossRef] [PubMed]

209. Velnar, T.; Bailey, T.; Smrkolj, V. The Wound Healing Process: An Overview of the Cellular and Molecular Mechanisms. J. Int. Med Res. 2009, 37, 1528-1542. [CrossRef]

210. Szpaderska, A.M.; DiPietro, L.A. Inflammation in surgical wound healing: Friend or foe? Surgery 2005, 137, 571-573. [CrossRef] [PubMed] 
211. Cha, H.; Hong, S.; Park, J.H.; Park, H.H. Stem Cell-Derived Exosomes and Nanovesicles: Promotion of Cell Proliferation, Migration, and Anti-Senescence for Treatment of Wound Damage and Skin Ageing. Pharmaceutics 2020, 12, 1135. [CrossRef]

212. Eming, S.A.; Martin, P.; Tomic-Canic, M. Wound repair and regeneration: Mechanisms, signaling, and translation. Sci. Transl. Med. 2014, 6, 265sr6. [CrossRef]

213. Chen, C.-C.; Mo, F.-E.; Lau, L.F. The Angiogenic Factor Cyr61 Activates a Genetic Program for Wound Healing in Human Skin Fibroblasts. J. Biol. Chem. 2001, 276, 47329-47337. [CrossRef] [PubMed]

214. Macedo, L.; Pinhal-Enfield, G.; Alshits, V.; Elson, G.; Cronstein, B.; Leibovich, S.J. Wound Healing Is Impaired in MyD88-Deficient Mice: A Role for MyD88 in the Regulation of Wound Healing by Adenosine A2A Receptors. Am. J. Pathol. 2007, 171, 1774-1788. [CrossRef] [PubMed]

215. Min, J.-K.; Lee, Y.-M.; Kim, J.H.; Kim, Y.-M.; Kim, S.W.; Lee, S.-Y.; Gho, Y.S.; Oh, G.T.; Kwon, Y.-G. Hepatocyte Growth Factor Suppresses Vascular Endothelial Growth Factor-Induced Expression of Endothelial ICAM-1 and VCAM-1 by Inhibiting the Nuclear Factor-кB Pathway. Circ. Res. 2005, 96, 300-307. [CrossRef]

216. Pola, R.; Ling, L.E.; Silver, M.; Corbley, M.J.; Kearney, M.; Pepinsky, R.B.; Shapiro, R.; Taylor, F.R.; Baker, D.P.; Asahara, T.; et al The morphogen Sonic hedgehog is an indirect angiogenic agent upregulating two families of angiogenic growth factors. Nat. Med. 2001, 7, 706-711. [CrossRef]

217. Shiffman, M. Stem Cells in Aesthetic Procedures: Art, Science, and Clinical Techniques; Springer: Berlin/Heidelberg, Germany, 2014.

218. Zhang, Z.; Schluesener, H.J. Mammalian toll-like receptors: From endogenous ligands to tissue regeneration. Cell. Mol. Life Sci. 2006, 63, 2901-2907. [CrossRef]

219. Ishida, Y.; Gao, J.-L.; Murphy, P.M. Chemokine Receptor CX3CR1 Mediates Skin Wound Healing by Promoting Macrophage and Fibroblast Accumulation and Function. J. Immunol. 2007, 180, 569-579. [CrossRef]

220. Ishida, Y.; Kondo, T.; Kimura, A.; Matsushima, K.; Mukaida, N. Absence of IL-1 Receptor Antagonist Impaired Wound Healing along with Aberrant NF-kB Activation and a Reciprocal Suppression of TGF- $\beta$ Signal Pathway. J. Immunol. 2006, 176, 5598-5606. [CrossRef]

221. Barrientos, S.; Stojadinovic, O.; Golinko, M.S.; Brem, H.; Tomic-Canic, M. PERSPECTIVE ARTICLE: Growth factors and cytokines in wound healing. Wound Repair Regen. 2008, 16, 585-601. [CrossRef] [PubMed]

222. Lamar, J.; Iyer, V.; DiPersio, C.M. Integrin $\alpha 3 \beta 1$ Potentiates TGF $\beta$-Mediated Induction of MMP-9 in Immortalized Keratinocytes. J. Investig. Dermatol. 2008, 128, 575-586. [CrossRef]

223. Munger, J.S.; Sheppard, D. Cross Talk among TGF- Signaling Pathways, Integrins, and the Extracellular Matrix. Cold Spring Harb. Perspect. Biol. 2011, 3, a005017. [CrossRef]

224. Pastar, I.; Stojadinovic, O.; Krzyzanowska, A.; Barrientos, S.; Stuelten, C.; Zimmerman, K.; Blumenberg, M.; Brem, H.; Tomic-Canic, M. Attenuation of the Transforming Growth Factor $\beta$-Signaling Pathway in Chronic Venous Ulcers. Mol. Med. 2010, 16, 92-101. [CrossRef]

225. Philipp, K.; Riedel, F.; Germann, G.; Hormann, K.; Sauerbier, M. TGF- $\beta$ antisense oligonucleotides reduce mRNA expression of matrix metalloproteinases in cultured wound-healing-related cells. Int. J. Mol. Med. 2005, 15, 299-303. [CrossRef] [PubMed]

226. Shapouri-Moghaddam, A.; Mohammadian, S.; Vazini, H.; Taghadosi, M.; Esmaeili, S.-A.; Mardani, F.; Seifi, B.; Mohammadi, A.; Afshari, J.T.; Sahebkar, A. Macrophage plasticity, polarization, and function in health and disease. J. Cell. Physiol. 2018, 233, 6425-6440. [CrossRef]

227. Stuelten, C.; Byfield, S.D.; Arany, P.; Karpova, T.; Stetler-Stevenson, W.; Roberts, A.B. Breast cancer cells induce stromal fibroblasts to express MMP-9 via secretion of TNF- $\alpha$ and TGF- $\beta$. J. Cell Sci. 2005, 118, 2143-2153. [CrossRef] [PubMed]

228. Yuan, W.; Varga, J. Transforming Growth Factor- $\beta$ Repression of Matrix Metalloproteinase-1 in Dermal Fibroblasts Involves Smad3. J. Biol. Chem. 2001, 276, 38502-38510. [CrossRef] [PubMed]

229. Lin, Z.-Q.; Kondo, T.; Ishida, Y.; Takayasu, T.; Mukaida, N. Essential involvement of IL-6 in the skin wound-healing process as evidenced by delayed wound healing in IL-6-deficient mice. J. Leukoc. Biol. 2003, 73, 713-721. [CrossRef] [PubMed]

230. Mast, B.A.; Schultz, G.S. Interactions of cytokines, growth factors, and proteases in acute and chronic wounds. Wound Repair Regen. 1996, 4, 411-420. [CrossRef]

231. McFarland-Mancini, M.M.; Funk, H.M.; Paluch, A.M.; Zhou, M.; Giridhar, P.V.; Mercer, C.; Kozma, S.C.; Drew, A.F. Differences in Wound Healing in Mice with Deficiency of IL-6 versus IL-6 Receptor. J. Immunol. 2010, 184, 7219-7228. [CrossRef]

232. Di-Poï, N.; Tan, N.S.; Michalik, L.; Wahli, W.; Desvergne, B. Antiapoptotic Role of PPAR $\beta$ in Keratinocytes via Transcriptional Control of the Akt1 Signaling Pathway. Mol. Cell 2002, 10, 721-733. [CrossRef]

233. Tan, N.S.; Michalik, L.; Di-Poï, N.; Desvergne, B.; Wahli, W. Critical roles of the nuclear receptor PPAR $\beta$ (peroxisome-proliferatoractivated receptor $\beta$ ) in skin wound healing. Biochem. Soc. Trans. 2004, 32, 97-102. [CrossRef] [PubMed]

234. Wiegand, C.; Schönfelder, U.; Abel, M.; Ruth, P.; Kaatz, M.; Hipler, U.-C. Protease and pro-inflammatory cytokine concentrations are elevated in chronic compared to acute wounds and can be modulated by collagen type I in vitro. Arch. Dermatol. Res. 2009, 302, 419-428. [CrossRef] [PubMed]

235. Yan, C.; Gao, N.; Sun, H.; Yin, J.; Lee, P.; Zhou, L.; Fan, X.; Yu, F.-S. Targeting Imbalance between IL-1 $\beta$ and IL-1 Receptor Antagonist Ameliorates Delayed Epithelium Wound Healing in Diabetic Mouse Corneas. Am. J. Pathol. 2016, 186, 1466-1480. [CrossRef] [PubMed]

236. Rodrigues, M.; Kosaric, N.; Bonham, C.A.; Gurtner, G.C. Wound Healing: A Cellular Perspective. Physiol. Rev. 2019, 99, 665-706. [CrossRef] [PubMed] 
237. Rückerl, D.; Heßmann, M.; Yoshimoto, T.; Ehlers, S.; Hölscher, C. Alternatively activated macrophages express the IL-27 receptor alpha chain WSX-1. Immunobiology 2006, 211, 427-436. [CrossRef]

238. Yang, B.; Suwanpradid, J.; Sanchez, R.T.; Choi, H.W.; Hoang, P.; Wang, D.; Abraham, S.N.; MacLeod, A.S. IL-27 Facilitates Skin Wound Healing through Induction of Epidermal Proliferation and Host Defense. J. Investig. Dermatol. 2017, 137, 1166-1175. [CrossRef]

239. Xu, H.; Fan, G. The Role of Cytokines in Modulating Vocal Fold Fibrosis: A Contemporary Review. Laryngoscope 2021, 131, 139-145. [CrossRef]

240. Antsiferova, M.; E Klatte, J.; Bodó, E.; Paus, R.; Jorcano, J.L.; Matzuk, M.M.; Werner, S.; Kögel, H. Keratinocyte-derived follistatin regulates epidermal homeostasis and wound repair. Lab. Investig. 2008, 89, 131-141. [CrossRef] [PubMed]

241. Kuai, L.; Zhang, J.-T.; Deng, Y.; Xu, S.; Xu, X.-Z.; Wu, M.-F.; Guo, D.-J.; Chen, Y.; Wu, R.-J.; Zhao, X.-Q.; et al. Sheng-ji Hua-yu formula promotes diabetic wound healing of re-epithelization via Activin/Follistatin regulation. BMC Complement. Altern. Med. 2018, 18, 32. [CrossRef]

242. Werner, S.; Alzheimer, C. Roles of activin in tissue repair, fibrosis, and inflammatory disease. Cytokine Growth Factor Rev. 2006, 17, 157-171. [CrossRef]

243. Werner, S.; Beer, H.-D.; Mauch, C.; Lüscher, B.; Werner, S. The Mad1 transcription factor is a novel target of activin and TGF- $\beta$ action in keratinocytes: Possible role of Mad1 in wound repair and psoriasis. Oncogene 2001, 20, 7494-7504. [CrossRef] [PubMed]

244. Bikfalvi, A.; Klein, S.; Pintucci, G.; Rifkin, D.B. Biological Roles of Fibroblast Growth Factor-2*. Endocr. Rev. 1997, 18, 26-45. [CrossRef] [PubMed]

245. Greenhalgh, D.G.; Sprugel, K.H.; Murray, M.J.; Ross, R. PDGF and FGF stimulate wound healing in the genetically diabetic mouse. Am. J. Pathol. 1990, 136, 1235-1246. [PubMed]

246. Pierce, G.F.; Berg, J.V.; Rudolph, R.; Tarpley, J.; Mustoe, T.A. Platelet-derived growth factor-BB and transforming growth factor beta 1 selectively modulate glycosaminoglycans, collagen, and myofibroblasts in excisional wounds. Am. J. Pathol. 1991, 138, 629-646. [PubMed]

247. Powers, C.J.; McLeskey, S.W.; Wellstein, A. Fibroblast growth factors, their receptors and signaling. Endocrine-Related Cancer 2000, 7, 165-197. [CrossRef] [PubMed]

248. Soares, C.D.; Morais, T.M.L.; Araújo, R.M.F.G.; Meyer, P.F.; Oliveira, E.A.F.; Silva, R.M.V.; Carreiro, E.M.; Carreiro, E.P.; Belloco, V.G.; Mariz, B.A.L.A.; et al. Effects of subcutaneous injection of ozone during wound healing in rats. Growth Factors 2019, 37, 95-103. [CrossRef] [PubMed]

249. Pengzong, Z.; Yuanmin, L.; Xiaoming, X.; Shang, D.; Wei, X.; Zhigang, L.; Dongzhou, D.; Wenjing, Y.; Jianbiao, Y.; Yang, X.; et al. Wound Healing Potential of the Standardized Extract of Boswellia serrata on Experimental Diabetic Foot Ulcer via Inhibition of Inflammatory, Angiogenetic and Apoptotic Markers. Planta Medica 2019, 85, 657-669. [CrossRef]

250. Dinh, P.-U.C.; Paudel, D.; Brochu, H.; Popowski, K.D.; Gracieux, M.C.; Cores, J.; Huang, K.; Hensley, M.T.; Harrell, E.; Vandergriff, A.C.; et al. Inhalation of lung spheroid cell secretome and exosomes promotes lung repair in pulmonary fibrosis. Nat. Commun. 2020, 11, 1064. [CrossRef]

251. Jiang, C.K.; Magnaldo, T.; Ohtsuki, M.; Freedberg, I.M.; Bernerd, F.; Blumenberg, M. Epidermal growth factor and transforming growth factor alpha specifically induce the activation- and hyperproliferation-associated keratins 6 and 16. Proc. Natl. Acad. Sci. USA 1993, 90, 6786-6790. [CrossRef]

252. Oda, K.; Matsuoka, Y.; Funahashi, A.; Kitano, H. A comprehensive pathway map of epidermal growth factor receptor signaling. Mol. Syst. Biol. 2005, 1, 2005.0010. [CrossRef]

253. Shirakata, Y.; Kimura, R.; Nanba, D.; Iwamoto, R.; Tokumaru, S.; Morimoto, C.; Yokota, K.; Nakamura, M.; Sayama, K.; Mekada, E.; et al. Heparin-binding EGF-like growth factor accelerates keratinocyte migration and skin wound healing. J. Cell Sci. 2005, 118, 2363-2370. [CrossRef] [PubMed]

254. Zhu, Y.-Z.; Hu, X.; Zhang, J.; Wang, Z.-H.; Wu, S.; Yi, Y.-Y. Extracellular Vesicles Derived From Human Adipose-Derived Stem Cell Prevent the Formation of Hypertrophic Scar in a Rabbit Model. Ann. Plast. Surg. 2020, 84, 602-607. [CrossRef]

255. Braun, S.; Keller, U.A.D.; Steiling, H.; Werner, S. Fibroblast growth factors in epithelial repair and cytoprotection. Philos. Trans. R. Soc. B: Biol. Sci. 2004, 359, 753-757. [CrossRef]

256. Plichta, J.K.; Radek, K.A. Sugar-Coating Wound Repair. J. Burn. Care Res. 2012, 33, 299-310. [CrossRef] [PubMed]

257. Seeger, M.; Paller, A.S. The Roles of Growth Factors in Keratinocyte Migration. Adv. Wound Care 2015, 4, 213-224. [CrossRef] [PubMed]

258. Di, R.; Murray, A.F.; Xiong, J.; Esposito, D.; Komarnytsky, S.; Gianfagna, T.J.; Munafo, J.P. Lily steroidal glycoalkaloid promotes early inflammatory resolution in wounded human fibroblasts. J. Ethnopharmacol. 2020, 258, 112766. [CrossRef]

259. Satish, L.; Wells, A.; Yager, D. Glu-Leu-Arg-Negative CXC Chemokine Interferon $\gamma$ Inducible Protein-9 As a Mediator of Epidermal-Dermal Communication During Wound Repair. J. Investig. Dermatol. 2003, 120, 1110-1117. [CrossRef]

260. Tortelli, F.; Pisano, M.; Briquez, P.S.; Martino, M.M.; Hubbell, J.A. Fibronectin Binding Modulates CXCL11 Activity and Facilitates Wound Healing. PLoS ONE 2013, 8, e79610. [CrossRef]

261. Rajesh, A.; Stuart, G.; Real, N.; Ahn, J.; Tschirley, A.; Wise, L.; Hibma, M. Depletion of langerin + cells enhances cutaneous wound healing. Immunology 2020, 160, 366-381. [CrossRef] [PubMed] 
262. Kim, B.-S.; Breuer, B.; Arnke, K.; Ruhl, T.; Hofer, T.; Simons, D.; Knobe, M.; Ganse, B.; Guidi, M.; Beier, J.P.; et al. The effect of the macrophage migration inhibitory factor (MIF) on excisional wound healing in vivo. J. Plast. Surg. Hand Surg. 2020, 54, 137-144. [CrossRef] [PubMed]

263. Teng, M.; Huang, Y.; Zhang, H. Application of stems cells in wound healing-An update. Wound Repair Regen. 2014, 22, 151-160. [CrossRef]

264. Chen, L.; Tredget, E.E.; Wu, P.Y.G.; Wu, Y. Paracrine Factors of Mesenchymal Stem Cells Recruit Macrophages and Endothelial Lineage Cells and Enhance Wound Healing. PLoS ONE 2008, 3, e1886. [CrossRef]

265. Yew, T.-L.; Hung, Y.-T.; Li, H.-Y.; Chen, H.-W.; Chen, L.-L.; Tsai, K.-S.; Chiou, S.-H.; Chao, K.-C.; Huang, T.-F.; Chen, H.-L.; et al. Enhancement of Wound Healing by Human Multipotent Stromal Cell Conditioned Medium: The Paracrine Factors and p38 MAPK Activation. Cell Transplant. 2011, 20, 693-706. [CrossRef]

266. Cardoso, R.M.S.; Rodrigues, S.C.; Gomes, C.F.; Duarte, F.V.; Romao, M.; Leal, E.C.; Freire, P.C.; Neves, R.; Simões-Correia, J. Development of an optimized and scalable method for isolation of umbilical cord blood-derived small extracellular vesicles for future clinical use. Stem Cells Transl. Med. 2021, 10, 910-921. [CrossRef] [PubMed]

267. Hu, L.; Wang, J.; Zhou, X.; Xiong, Z.; Zhao, J.; Yu, R.; Huang, F.; Zhang, H.; Chen, L. Exosomes derived from human adipose mensenchymal stem cells accelerates cutaneous wound healing via optimizing the characteristics of fibroblasts. Sci. Rep. 2016, 6, 32993. [CrossRef]

268. Ding, J.; Wang, X.; Chen, B.; Zhang, J.; Xu, J. Exosomes Derived from Human Bone Marrow Mesenchymal Stem Cells Stimulated by Deferoxamine Accelerate Cutaneous Wound Healing by Promoting Angiogenesis. BioMed Res. Int. 2019, $2019,9742765$. [CrossRef]

269. Goodarzi, P.; Larijani, B.; Alavi-Moghadam, S.; Tayanloo-Beik, A.; Mohamadi-Jahani, F.; Ranjbaran, N.; Payab, M.; Falahzadeh, K.; Mousavi, M.; Arjmand, B. Mesenchymal Stem Cells-Derived Exosomes for Wound Regeneration. Adv. Exp. Med. Biol. 2018, 1119, 119-131. [CrossRef] [PubMed]

270. Han, G.; Ceilley, R. Chronic Wound Healing: A Review of Current Management and Treatments. Adv. Ther. 2017, 34, 599-610. [CrossRef] [PubMed]

271. McBride, J.D.; Jenkins, A.; Liu, X.; Zhang, B.; Lee, K.; Berry, W.L.; Janknecht, R.; Griffin, C.T.; Aston, C.E.; Lyons, T.J.; et al Elevated Circulation Levels of an Antiangiogenic SERPIN in Patients with Diabetic Microvascular Complications Impair Wound Healing through Suppression of Wnt Signaling. J. Investig. Dermatol. 2014, 134, 1725-1734. [CrossRef]

272. Ren, S.; Chen, J.; Duscher, D.; Liu, Y.; Guo, G.; Kang, Y.; Xiong, H.; Zhan, P.; Wang, Y.; Wang, C.; et al. Microvesicles from human adipose stem cells promote wound healing by optimizing cellular functions via AKT and ERK signaling pathways. Stem Cell Res. Ther. 2019, 10, 1-14. [CrossRef]

273. Zhang, B.; Wang, M.; Gong, A.; Zhang, X.; Wu, X.; Zhu, Y.; Shi, H.; Wu, L.; Zhu, W.; Qian, H.; et al. HucMSC-Exosome Mediated-Wnt4 Signaling Is Required for Cutaneous Wound Healing. Stem Cells 2015, 33, 2158-2168. [CrossRef] [PubMed]

274. Hoang, D.H.; Nguyen, T.D.; Nguyen, H.-P.; Nguyen, X.-H.; Do, P.T.X.; Dang, V.D.; Dam, P.T.M.; Bui, H.T.H.; Trinh, M.Q.; Vu, D.M.; et al. Differential Wound Healing Capacity of Mesenchymal Stem Cell-Derived Exosomes Originated From Bone Marrow, Adipose Tissue and Umbilical Cord Under Serum- and Xeno-Free Condition. Front. Mol. Biosci. 2020, 7, 119. [CrossRef] [PubMed]

275. Kim, Y.-J.; Yoo, S.M.; Park, H.H.; Lim, H.J.; Kim, Y.-L.; Lee, S.; Seo, K.-W.; Kang, K.-S. Exosomes derived from human umbilical cord blood mesenchymal stem cells stimulates rejuvenation of human skin. Biochem. Biophys. Res. Commun. 2017, 493, 1102-1108. [CrossRef]

276. Jiang, T.; Wang, Z.; Sun, J. Human bone marrow mesenchymal stem cell-derived exosomes stimulate cutaneous wound healing mediates through TGF- $\beta$ /Smad signaling pathway. Stem Cell Res. Ther. 2020, 11, 1-10. [CrossRef]

277. Shi, A.; Li, J.; Qiu, X.; Sabbah, M.; Boroumand, S.; Huang, T.C.-T.; Zhao, C.; Terzic, A.; Behfar, A.; Moran, S.L. TGF- $\beta$ loaded exosome enhances ischemic wound healing in vitro and in vivo. Theranostics 2021, 11, 6616-6631. [CrossRef] [PubMed]

278. Heo, J.S.; Kim, S.; Yang, C.E.; Choi, Y.; Song, S.Y.; Kim, H.O. Human Adipose Mesenchymal Stem Cell-Derived Exosomes: A Key Player in Wound Healing. Tissue Eng. Regen. Med. 2021, 1-12. [CrossRef]

279. Banerjee, J.; Chan, Y.C.; Sen, C.K. Micrornas in skin and wound healing. Physiol. Genom. 2011, 43, 543-556. [CrossRef]

280. Ferguson, S.W.; Wang, J.; Lee, C.J.; Liu, M.; Neelamegham, S.; Canty, J.M.; Nguyen, J. The microRNA regulatory landscape of MSC-derived exosomes: A systems view. Sci. Rep. 2018, 8, 1419. [CrossRef]

281. Qiu, G.; Zheng, G.; Ge, M.; Wang, J.; Huang, R.; Shu, Q.; Xu, J. Mesenchymal stem cell-derived extracellular vesicles affect disease outcomes via transfer of microRNAs. Stem Cell Res. Ther. 2018, 9, 320. [CrossRef]

282. Reza, A.M.M.T.; Choi, Y.-J.; Yasuda, H.; Kim, J.-H. Human adipose mesenchymal stem cell-derived exosomal-miRNAs are critical factors for inducing anti-proliferation signalling to A2780 and SKOV-3 ovarian cancer cells. Sci. Rep. 2016, 6, 38498. [CrossRef]

283. Soliman, A.M.; Das, S.; Ghafar, N.A.; Teoh, S.L. Role of MicroRNA in Proliferation Phase of Wound Healing. Front. Genet. 2018, 9. [CrossRef] [PubMed]

284. Gil You, D.; Lim, G.T.; Kwon, S.; Um, W.; Oh, B.H.; Song, S.H.; Lee, J.; Jo, D.-G.; Cho, Y.W.; Park, J.H. Metabolically engineered stem cell-derived exosomes to regulate macrophage heterogeneity in rheumatoid arthritis. Sci. Adv. 2021, 7, 0083. [CrossRef]

285. Herter, E.K.; Landén, N.X. Non-Coding RNAs: New Players in Skin Wound Healing. Adv. Wound Care 2017, 6, 93-107. [CrossRef] [PubMed]

286. Mulholland, E.; Dunne, N.; McCarthy, H.O. MicroRNA as Therapeutic Targets for Chronic Wound Healing. Mol. Ther. Nucleic Acids 2017, 8, 46-55. [CrossRef] [PubMed] 
287. Nahid, A.; Yao, B.; Dominguez-Gutierrez, P.R.; Kesavalu, L.; Satoh, M.; Chan, E.K.L. Regulation of TLR2-Mediated Tolerance and Cross-Tolerance through IRAK4 Modulation by miR-132 and miR-212. J. Immunol. 2013, 190, 1250-1263. [CrossRef]

288. Essandoh, K.; Li, Y.; Huo, J.; Fan, G.-C. MiRNA-Mediated Macrophage Polarization and its Potential Role in the Regulation of Inflammatory Response. Shock 2016, 46, 122-131. [CrossRef]

289. Li, N.; Landén, N.X. MicroRNAs in skin wound healing. Eur. J. Dermatol. EJD 2017, 27, 12-14. [CrossRef]

290. Wang, Y.; Han, B.; Wang, Y.; Wang, C.; Zhang, H.; Xue, J.; Wang, X.; Niu, T.; Niu, Z.; Chen, Y. Mesenchymal stem cell-secreted extracellular vesicles carrying TGF- $\beta 1$ up-regulate miR-132 and promote mouse M2 macrophage polarization. J. Cell. Mol. Med. 2020, 24, 12750-12764. [CrossRef]

291. Chen, C.-Y.; Rao, S.-S.; Ren, L.; Hu, X.-K.; Tan, Y.-J.; Hu, Y.; Luo, J.; Liu, Y.-W.; Yin, H.; Huang, J.; et al. Exosomal DMBT1 from human urine-derived stem cells facilitates diabetic wound repair by promoting angiogenesis. Theranostics 2018, 8, 1607-1623. [CrossRef]

292. Tao, S.-C.; Guo, S.-C.; Li, M.; Ke, Q.-F.; Guo, Y.-P.; Zhang, C.-Q. Chitosan Wound Dressings Incorporating Exosomes Derived from MicroRNA-126-Overexpressing Synovium Mesenchymal Stem Cells Provide Sustained Release of Exosomes and Heal Full-Thickness Skin Defects in a Diabetic Rat Model. Stem Cells Transl. Med. 2016, 6, 736-747. [CrossRef]

293. Templeton, D.M.; Liu, Y. Genetic regulation of cell function in response to iron overload or chelation. Biochim. et Biophys. Acta (BBA) Gen. Subj. 2003, 1619, 113-124. [CrossRef]

294. Luo, Z.; Wu, F.; Xue, E.; Huang, L.; Yan, P.; Pan, X.; Zhou, Y. Hypoxia preconditioning promotes bone marrow mesenchymal stem cells survival by inducing HIF-1 $\alpha$ in injured neuronal cells derived exosomes culture system. Cell Death Dis. 2019, 10, 1-13. [CrossRef] [PubMed]

295. Wang, S.Y.; Kim, H.; Kwak, G.; Jo, S.D.; Cho, D.; Yang, Y.; Kwon, I.C.; Jeong, J.H.; Kim, S.H. Development of microRNA-21 mimic nanocarriers for the treatment of cutaneous wounds. Theranostics 2020, 10, 3240-3253. [CrossRef] [PubMed]

296. Yang, X.; Wang, J.; Guo, S.-L.; Fan, K.-J.; Li, J.; Wang, Y.-L.; Teng, Y.; Yang, X. miR-21 Promotes Keratinocyte Migration and Re-epithelialization During Wound Healing. Int. J. Biol. Sci. 2011, 7, 685-690. [CrossRef] [PubMed]

297. Shi, R.; Jin, Y.; Hu, W.; Lian, W.; Cao, C.; Han, S.; Zhao, S.; Yuan, H.; Yang, X.; Shi, J.; et al. Exosomes derived from mmu_circ_0000250-modified adipose-derived mesenchymal stem cells promote wound healing in diabetic mice by inducing miR-128-3p/SIRT1-mediated autophagy. Am. J. Physiol. Physiol. 2020, 318, C848-C856. [CrossRef]

298. Zhang, B.; Shi, Y.; Gong, A.; Pan, Z.; Shi, H.; Yang, H.; Fu, H.; Yan, Y.; Zhang, X.; Wang, M.; et al. HucMSC Exosome-Delivered 14-3-3 $\zeta$ Orchestrates Self-Control of the Wnt Response via Modulation of YAP During Cutaneous Regeneration. Stem Cells 2016, 34, 2485-2500. [CrossRef]

299. Choi, J.S.; Cho, W.L.; Choi, Y.J.; Kim, J.D.; Park, H.-A.; Kim, S.Y.; Park, J.H.; Jo, D.-G.; Cho, Y.W. Functional recovery in photodamaged human dermal fibroblasts by human adipose-derived stem cell extracellular vesicles. J. Extracell. Vesicles 2019, 8 , 1565885. [CrossRef]

300. Ferreira, A.D.F.; Cunha, P.D.S.; Carregal, V.M.; Silva, P.D.C.D.; De Miranda, M.C.; Kunrath-Lima, M.; De Melo, M.I.A.; Faraco, C.C.F.; Barbosa, J.L.; Frezard, F.; et al. Extracellular Vesicles from Adipose-Derived Mesenchymal Stem/Stromal Cells Accelerate Migration and Activate AKT Pathway in Human Keratinocytes and Fibroblasts Independently of miR-205 Activity. Stem Cells Int. 2017, 2017, 9841035. [CrossRef]

301. Henriques-Antunes, H.; Cardoso, R.; Zonari, A.; Correia, J.S.; Leal, E.; Jiménez-Balsa, A.; Lino, M.M.; Barradas, A.; Kostic, I.; Gomes, C.; et al. The Kinetics of Small Extracellular Vesicle Delivery Impacts Skin Tissue Regeneration. ACS Nano 2019, 13, 8694-8707. [CrossRef]

302. Li, M.; Ke, Q.-F.; Tao, S.-C.; Guo, S.-C.; Rui, B.-Y.; Guo, Y.-P. Fabrication of hydroxyapatite/chitosan composite hydrogels loaded with exosomes derived from miR-126-3p overexpressed synovial mesenchymal stem cells for diabetic chronic wound healing. $J$. Mater. Chem. B 2016, 4, 6830-6841. [CrossRef]

303. Huang, J.; Xiong, J.; Yang, L.; Zhang, J.; Sun, S.; Liang, Y. Cell-free exosome-laden scaffolds for tissue repair. Nanoscale 2021, 13, 8740-8750. [CrossRef]

304. Cooper, D.R.; Wang, C.; Patel, R.; Trujillo, A.; Patel, N.A.; Prather, J.; Gould, L.J.; Wu, M.H. Human Adipose-Derived Stem Cell Conditioned Media and Exosomes Containing MALAT1 Promote Human Dermal Fibroblast Migration and Ischemic Wound Healing. Adv. Wound Care 2018, 7, 299-308. [CrossRef] [PubMed]

305. Fang, S.; Xu, C.; Zhang, Y.; Xue, C.; Yang, C.; Bi, H.; Qian, X.; Wu, M.; Ji, K.; Zhao, Y.; et al. Umbilical Cord-Derived Mesenchymal Stem Cell-Derived Exosomal MicroRNAs Suppress Myofibroblast Differentiation by Inhibiting the Transforming Growth Factor$\beta /$ SMAD2 Pathway During Wound Healing. Stem Cells Transl. Med. 2016, 5, 1425-1439. [CrossRef]

306. Ti, D.; Hao, H.; Tong, C.; Liu, J.; Dong, L.; Zheng, J.; Zhao, Y.; Liu, H.; Fu, X.; Han, W. LPS-preconditioned mesenchymal stromal cells modify macrophage polarization for resolution of chronic inflammation via exosome-shuttled let-7b. J. Transl. Med. 2015, 13, 308. [CrossRef]

307. Bian, X.; Li, B.; Yang, J.; Ma, K.; Sun, M.; Zhang, C.; Fu, X. Regenerative and protective effects of dMSC-sEVs on high-glucoseinduced senescent fibroblasts by suppressing RAGE pathway and activating Smad pathway. Stem Cell Res. Ther. 2020, 11, 1-16. [CrossRef] [PubMed]

308. Kim, D.-K.; Nishida, H.; An, S.Y.; Shetty, A.K.; Bartosh, T.J.; Prockop, D.J. Chromatographically isolated CD63+CD81+ extracellular vesicles from mesenchymal stromal cells rescue cognitive impairments after TBI. Proc. Natl. Acad. Sci. 2016, 113, 170-175. [CrossRef] 
309. Shi, Y.; Shi, H.; Nomi, A.; Lei-Lei, Z.; Zhang, B.; Qian, H. Mesenchymal stem cell-derived extracellular vesicles: A new impetus of promoting angiogenesis in tissue regeneration. Cytotherapy 2019, 21, 497-508. [CrossRef]

310. Forsberg, M.H.; Kink, J.A.; Hematti, P.; Capitini, C.M. Mesenchymal Stromal Cells and Exosomes: Progress and Challenges. Front. Cell Dev. Biol. 2020, 8, 665. [CrossRef]

311. Dabrowska, S.; Andrzejewska, A.; Lukomska, B.; Janowski, M. Neuroinflammation as a target for treatment of stroke using mesenchymal stem cells and extracellular vesicles. J. Neuroinflamm. 2019, 16, 178. [CrossRef] [PubMed]

312. Kharazi, U.; Badalzadeh, R. A review on the stem cell therapy and an introduction to exosomes as a new tool in reproductive medicine. Reprod. Biol. 2020, 20, 447-459. [CrossRef]

313. Rahmani, A.; Saleki, K.; Javanmehr, N.; Khodaparast, J.; Saadat, P.; Nouri, H.R. Mesenchymal stem cell-derived extracellular vesicle-based therapies protect against coupled degeneration of the central nervous and vascular systems in stroke. Ageing Res. Rev. 2020, 62, 101106. [CrossRef]

314. Roura, S.; Monguió-Tortajada, M.; Munizaga-Larroudé, M.; Clos-Sansalvador, M.; Franquesa, M.; Rosell, A.; Borràs, F.E. Potential of Extracellular Vesicle-Associated TSG-6 from Adipose Mesenchymal Stromal Cells in Traumatic Brain Injury. Int. J. Mol. Sci. 2020, 21, 6761. [CrossRef] [PubMed]

315. Zhang, Y.; Chopp, M.; Zhang, Z.G.; Katakowski, M.; Xin, H.; Qu, C.; Ali, M.; Mahmood, A.; Xiong, Y. Systemic administration of cell-free exosomes generated by human bone marrow derived mesenchymal stem cells cultured under 2D and 3D conditions improves functional recovery in rats after traumatic brain injury. Neurochem. Int. 2017, 111, 69-81. [CrossRef] [PubMed]

316. Zhang, L.; Li, Y.-J.; Wu, X.-Y.; Hong, Z.; Wei, W.-S. MicroRNA-181c negatively regulates the inflammatory response in oxygenglucose-deprived microglia by targeting Toll-like receptor 4. J. Neurochem. 2015, 132, 713-723. [CrossRef] [PubMed]

317. Zhang, Z.G.; Buller, B.; Chopp, M. Exosomes-Beyond stem cells for restorative therapy in stroke and neurological injury. Nat. Rev. Neurol. 2019, 15, 193-203. [CrossRef] [PubMed]

318. Muhammad, S.A. Mesenchymal stromal cell secretome as a therapeutic strategy for traumatic brain injury. BioFactors 2019, 45, 880-891. [CrossRef] [PubMed]

319. Kim, S.; Lee, S.K.; Kim, H.; Kim, T.M. Exosomes Secreted from Induced Pluripotent Stem Cell-Derived Mesenchymal Stem Cells Accelerate Skin Cell Proliferation. Int. J. Mol. Sci. 2018, 19, 3119. [CrossRef]

320. Xiong, Y.; Mahmood, A.; Chopp, M. Emerging potential of exosomes for treatment of traumatic brain injury. Neural Regen. Res. 2017, 12, 19-22. [CrossRef]

321. Singh, M.; Pandey, P.K.; Bhasin, A.; Padma, M.V.; Mohanty, S. Application of Stem Cells in Stroke: A Multifactorial Approach. Front. Neurosci. 2020, 14, 473. [CrossRef]

322. Yousif, G.; Qadri, S.; Haik, M.; Haik, Y.; Parray, A.S.; Shuaib, A. Circulating Exosomes of Neuronal Origin as Potential Early Biomarkers for Development of Stroke. Mol. Diagn. Ther. 2021, 25, 163-180. [CrossRef]

323. Hong, S.-B.; Yang, H.; Manaenko, A.; Lu, J.; Mei, Q.; Hu, Q. Potential of Exosomes for the Treatment of Stroke. Cell Transplant. 2018, 28, 662-670. [CrossRef]

324. Zagrean, A.-M.; Hermann, D.M.; Opris, I.; Zagrean, L.; Popa-Wagner, A. Multicellular Crosstalk Between Exosomes and the Neurovascular Unit After Cerebral Ischemia. Therapeutic Implications. Front. Neurosci. 2018, 12, 811. [CrossRef] [PubMed]

325. Chang, Y.-H.; Wu, K.-C.; Harn, H.-J.; Lin, S.-Z.; Ding, D.-C. Exosomes and Stem Cells in Degenerative Disease Diagnosis and Therapy. Cell Transplant. 2018, 27, 349-363. [CrossRef] [PubMed]

326. Chen, J.; Chopp, M. Exosome Therapy for Stroke. Stroke 2018, 49, 1083-1090. [CrossRef]

327. Cunningham, C.J.; Redondo-Castro, E.; Allan, S.M. The therapeutic potential of the mesenchymal stem cell secretome in ischaemic stroke. Br. J. Pharmacol. 2018, 38, 1276-1292. [CrossRef]

328. Najar, M.; Martel-Pelletier, J.; Pelletier, J.P.; Fahmi, H. Novel insights for improving the therapeutic safety and efficiency of mesenchymal stromal cells. World J. Stem Cells 2020, 12, 1474-1491. [CrossRef]

329. Xin, H.; Li, Y.; Cui, Y.; Yang, J.J.; Zhang, Z.G.; Chopp, M. Systemic Administration of Exosomes Released from Mesenchymal Stromal Cells Promote Functional Recovery and Neurovascular Plasticity After Stroke in Rats. J. Cereb. Blood Flow Metab. 2013, 33, 1711-1715. [CrossRef]

330. Zheng, X.; Hermann, D.M.; Bähr, M.; Doeppner, T.R. The role of small extracellular vesicles in cerebral and myocardial ischemiaMolecular signals, treatment targets, and future clinical translation. Stem Cells 2021, 39, 403-413. [CrossRef] [PubMed]

331. Um, S.; Ha, J.; Choi, S.J.; Oh, W.; Jin, H.J. Prospects for the therapeutic development of umbilical cord blood-derived mesenchymal stem cells. World J. Stem Cells 2020, 12, 1511-1528. [CrossRef]

332. Bang, O.Y.; Kim, E.H. Mesenchymal Stem Cell-Derived Extracellular Vesicle Therapy for Stroke: Challenges and Progress. Front. Neurol. 2019, 10, 211. [CrossRef]

333. Asrani, S.K.; Devarbhavi, H.; Eaton, J.; Kamath, P.S. Burden of liver diseases in the world. J. Hepatol. 2019, 70, 151-171. [CrossRef] [PubMed]

334. Bandopadhyay, M.; Bharadwaj, M. Exosomal miRNAs in hepatitis B virus related liver disease: A new hope for biomarker. Gut Pathog. 2020, 12, 23. [CrossRef]

335. Cho, Y.-E.; Kim, S.-H.; Lee, B.-H.; Baek, M.-C. Circulating Plasma and Exosomal microRNAs as Indicators of Drug-Induced Organ Injury in Rodent Models. Biomol. Ther. 2017, 25, 367-373. [CrossRef]

336. $\mathrm{Hu}, \mathrm{C}$; $\mathrm{Li}, \mathrm{L}$. Improvement of mesenchymal stromal cells and their derivatives for treating acute liver failure. J. Mol. Med. 2019, 97, 1065-1084. [CrossRef] [PubMed] 
337. Mahmood, A.; Seetharaman, R.; Kshatriya, P.; Patel, D.; Srivastava, A.S. Stem Cell Transplant for Advanced Stage Liver Disorders: Current Scenario and Future Prospects. Curr. Med. Chem. 2020, 27, 6276-6293. [CrossRef]

338. Momen-Heravi, F.; Saha, B.; Kodys, K.; Catalano, D.; Satishchandran, A.; Szabo, G. Increased number of circulating exosomes and their microRNA cargos are potential novel biomarkers in alcoholic hepatitis. J. Transl. Med. 2015, 13, 1-13. [CrossRef] [PubMed]

339. Tomimaru, Y.; Eguchi, H.; Nagano, H.; Wada, H.; Kobayashi, S.; Marubashi, S.; Tanemura, M.; Tomokuni, A.; Takemasa, I.; Umeshita, K.; et al. Circulating microRNA-21 as a novel biomarker for hepatocellular carcinoma. J. Hepatol. 2012, 56, 167-175. [CrossRef]

340. Chen, L.; Charrier, A.; Zhou, Y.; Chen, R.; Yu, B.; Agarwal, K.; Tsukamoto, H.; Lee, L.J.; Paulaitis, M.E.; Brigstock, D.R. Epigenetic regulation of connective tissue growth factor by MicroRNA-214 delivery in exosomes from mouse or human hepatic stellate cells. Hepatology 2014, 59, 1118-1129. [CrossRef]

341. Chen, L.; Chen, R.; Velazquez, V.M.; Brigstock, D.R. Fibrogenic Signaling Is Suppressed in Hepatic Stellate Cells through Targeting of Connective Tissue Growth Factor (CCN2) by Cellular or Exosomal MicroRNA-199a-5p. Am. J. Pathol. 2016, 186, $2921-2933$. [CrossRef]

342. Lee, Y.-S.; Kim, S.Y.; Ko, E.; Lee, J.-H.; Yi, H.-S.; Yoo, Y.J.; Je, J.; Suh, S.J.; Jung, Y.K.; Kim, J.H.; et al. Exosomes derived from palmitic acid-treated hepatocytes induce fibrotic activation of hepatic stellate cells. Sci. Rep. 2017, 7, 1-10. [CrossRef]

343. Jun, J.H.; Kim, J.Y.; Choi, J.H.; Lim, J.-Y.; Kim, K.; Kim, G.J. Exosomes from Placenta-Derived Mesenchymal Stem Cells Are Involved in Liver Regeneration in Hepatic Failure Induced by Bile Duct Ligation. Stem Cells Int. 2020, 2020, 5485738. [CrossRef] [PubMed]

344. Nojima, H.; Freeman, C.M.; Schuster, R.M.; Japtok, L.; Kleuser, B.; Edwards, M.J.; Gulbins, E.; Lentsch, A.B. Hepatocyte exosomes mediate liver repair and regeneration via sphingosine-1-phosphate. J. Hepatol. 2016, 64, 60-68. [CrossRef] [PubMed]

345. Tan, C.Y.; Lai, R.C.; Wong, W.; Dan, Y.Y.; Lim, S.-K.; Ho, H.K. Mesenchymal stem cell-derived exosomes promote hepatic regeneration in drug-induced liver injury models. Stem Cell Res. Ther. 2014, 5, 76. [CrossRef] [PubMed]

346. Yan, Y.; Jiang, W.; Tan, Y.; Zou, S.; Zhang, H.; Mao, F.; Gong, A.; Qian, H.; Xu, W. hucMSC Exosome-Derived GPX1 Is Required for the Recovery of Hepatic Oxidant Injury. Mol. Ther. 2017, 25, 465-479. [CrossRef] [PubMed]

347. Nong, K.; Wang, W.; Niu, X.; Hu, B.; Ma, C.; Bai, Y.; Wu, B.; Wang, Y.; Ai, K. Hepatoprotective effect of exosomes from humaninduced pluripotent stem cell-derived mesenchymal stromal cells against hepatic ischemia-reperfusion injury in rats. Cytotherapy 2016, 18, 1548-1559. [CrossRef] [PubMed]

348. Virani, S.S.; Alonso, A.; Benjamin, E.J.; Bittencourt, M.S.; Callaway, C.W.; Carson, A.P.; Chamberlain, A.M.; Chang, A.R.; Cheng, S.; Delling, F.N.; et al. Heart Disease and Stroke Statistics-2020 Update: A Report From the American Heart Association. Circulation 2020, 141, E139-E596. [CrossRef]

349. Zamani, P.; Fereydouni, N.; Butler, A.E.; Navashenaq, J.G.; Sahebkar, A. The therapeutic and diagnostic role of exosomes in cardiovascular diseases. Trends Cardiovasc. Med. 2019, 29, 313-323. [CrossRef]

350. Vagnozzi, R.J.; Maillet, M.; Sargent, M.A.; Khalil, H.; Johansen, A.K.Z.; Schwanekamp, J.A.; York, A.J.; Huang, V.; Nahrendorf, M.; Sadayappan, S.; et al. An acute immune response underlies the benefit of cardiac stem cell therapy. Nat. Cell Biol. 2020, 577, 405-409. [CrossRef]

351. Wysoczynski, M.; Khan, A.; Bolli, R. New Paradigms in Cell Therapy. Circ. Res. 2018, 123, 138-158. [CrossRef] [PubMed]

352. Bang, C.; Batkai, S.; Dangwal, S.; Gupta, S.K.; Foinquinos, A.; Holzmann, A.; Just, A.; Remke, J.; Zimmer, K.; Zeug, A.; et al. Cardiac fibroblast-derived microRNA passenger strand-enriched exosomes mediate cardiomyocyte hypertrophy. J. Clin. Investig. 2014, 124, 2136-2146. [CrossRef]

353. Barile, L.; Cervio, E.; Lionetti, V.; Milano, G.; Ciullo, A.; Biemmi, V.; Bolis, S.; Altomare, C.; Matteucci, M.; Di Silvestre, D.; et al. Cardioprotection by cardiac progenitor cell-secreted exosomes: Role of pregnancy-associated plasma protein-A. Cardiovasc. Res. 2018, 114, 992-1005. [CrossRef] [PubMed]

354. Beltrami, C.; Besnier, M.; Shantikumar, S.; Shearn, A.I.; Rajakaruna, C.; Laftah, A.; Sessa, F.; Spinetti, G.; Petretto, E.; Angelini, G.; et al. Human Pericardial Fluid Contains Exosomes Enriched with Cardiovascular-Expressed MicroRNAs and Promotes Therapeutic Angiogenesis. Mol. Ther. 2017, 25, 679-693. [CrossRef] [PubMed]

355. Minghua, W.; Zhijian, G.; Chahua, H.; Qiang, L.; Minxuan, X.; Luqiao, W.; Weifang, Z.; Peng, L.; Biming, Z.; Lingling, Y.; et al. Plasma exosomes induced by remote ischaemic preconditioning attenuate myocardial ischaemia/reperfusion injury by transferring miR-24. Cell Death Dis. 2018, 9, 1-14. [CrossRef]

356. Pironti, G.; Strachan, R.T.; Abraham, D.; Yu, S.M.-W.; Chen, M.; Chen, W.; Hanada, K.; Mao, L.; Watson, L.J.; Rockman, H.A. Circulating Exosomes Induced by Cardiac Pressure Overload Contain Functional Angiotensin II Type 1 Receptors. Circulation 2015, 131, 2120-2130. [CrossRef]

357. Qiao, L.; Hu, S.; Liu, S.; Zhang, H.; Ma, H.; Huang, K.; Li, Z.; Su, T.; Vandergriff, A.; Tang, J.; et al. microRNA-21-5p dysregulation in exosomes derived from heart failure patients impairs regenerative potential. J. Clin. Investig. 2019, 129, 2237-2250. [CrossRef]

358. Rautou, P.-E.; Bresson, J.; Sainte-Marie, Y.; Vion, A.-C.; Paradis, V.; Renard, J.; Devue, C.; Heymes, C.; Letteron, P.; Elkrief, L.; et al. Abnormal Plasma Microparticles Impair Vasoconstrictor Responses in Patients With Cirrhosis. Gastroenterology 2012, 143, 166-176. [CrossRef] [PubMed]

359. Sahoo, S.; Klychko, E.; Thorne, T.; Misener, S.; Schultz, K.M.; Millay, M.; Ito, A.; Liu, T.; Kamide, C.; Agrawal, H.; et al. Exosomes From Human CD34 + Stem Cells Mediate Their Proangiogenic Paracrine Activity. Circ. Res. 2011, 109, 724-728. [CrossRef] 
360. Yamaguchi, T.; Izumi, Y.; Nakamura, Y.; Yamazaki, T.; Shiota, M.; Sano, S.; Tanaka, M.; Osada-Oka, M.; Shimada, K.; Miura, K.; et al. Repeated remote ischemic conditioning attenuates left ventricular remodeling via exosome-mediated intercellular communication on chronic heart failure after myocardial infarction. Int. J. Cardiol. 2015, 178, 239-246. [CrossRef]

361. Beretti, F.; Zavatti, M.; Casciaro, F.; Comitini, G.; Franchi, F.; Barbieri, V.; La Sala, G.B.; Maraldi, T. Amniotic fluid stem cell exosomes: Therapeutic perspective. BioFactors 2018, 44, 158-167. [CrossRef] [PubMed]

362. Mentkowski, K.; Snitzer, J.D.; Rusnak, S.; Lang, J.K. Therapeutic Potential of Engineered Extracellular Vesicles. AAPS J. 2018, 20, 50. [CrossRef]

363. Giricz, Z.; Varga, Z.; Baranyai, T.; Sipos, P.; Pálóczi, K.; Kittel, Á.; Buzás, E.I.; Ferdinandy, P. Cardioprotection by remote ischemic preconditioning of the rat heart is mediated by extracellular vesicles. J. Mol. Cell. Cardiol. 2014, 68, 75-78. [CrossRef]

364. Sahoo, S.; Losordo, D. Exosomes and Cardiac Repair After Myocardial Infarction. Circ. Res. 2014, 114, 333-344. [CrossRef] [PubMed]

365. Vicencio, J.M.; Yellon, D.M.; Sivaraman, V.; Das, D.; Boi-Doku, C.; Arjun, S.; Zheng, Y.; A Riquelme, J.; Kearney, J.; Sharma, V.; et al. Plasma Exosomes Protect the Myocardium From Ischemia-Reperfusion Injury. J. Am. Coll. Cardiol. 2015, 65, 1525-1536. [CrossRef]

366. Huang, P.; Wang, L.; Li, Q.; Tian, X.; Xu, J.; Xu, J.; Xiong, Y.; Chen, G.; Qian, H.; Jin, C.; et al. Atorvastatin enhances the therapeutic efficacy of mesenchymal stem cells-derived exosomes in acute myocardial infarction via up-regulating long non-coding RNA H19. Cardiovasc. Res. 2020, 116, 353-367. [CrossRef]

367. Wang, X.; Chen, Y.; Zhao, Z.; Meng, Q.; Yu, Y.; Sun, J.; Yang, Z.; Chen, Y.; Li, J.; Ma, T.; et al. Engineered Exosomes With Ischemic Myocardium-Targeting Peptide for Targeted Therapy in Myocardial Infarction. J. Am. Hear. Assoc. 2018, 7, e008737. [CrossRef] [PubMed]

368. Pan, J.; Alimujiang, M.; Chen, Q.; Shi, H.; Luo, X. Exosomes derived from miR-146a-modified adipose-derived stem cells attenuate acute myocardial infarction-induced myocardial damage via downregulation of early growth response factor 1. J. Cell. Biochem. 2019, 120, 4433-4443. [CrossRef]

369. Liu, J.; Jiang, M.; Deng, S.; Lu, J.; Huang, H.; Zhang, Y.; Gong, P.; Shen, X.; Ruan, H.; Jin, M.; et al. miR-93-5p-Containing Exosomes Treatment Attenuates Acute Myocardial Infarction-Induced Myocardial Damage. Mol. Ther. Nucleic Acids 2018, 11, 103-115. [CrossRef] [PubMed]

370. Zhu, L.-P.; Tian, T.; Wang, J.-Y.; He, J.-N.; Chen, T.; Pan, M.; Xu, L.; Zhang, H.-X.; Qiu, X.-T.; Li, C.-C.; et al. Hypoxia-elicited mesenchymal stem cell-derived exosomes facilitates cardiac repair through miR-125b-mediated prevention of cell death in myocardial infarction. Theranostics 2018, 8, 6163-6177. [CrossRef] [PubMed]

371. Li, J.; Xue, H.; Li, T.; Chu, X.; Xin, D.; Xiong, Y.; Qiu, W.; Gao, X.; Qian, M.; Xu, J.; et al. Exosomes derived from mesenchymal stem cells attenuate the progression of atherosclerosis in ApoE- / - mice via miR-let7 mediated infiltration and polarization of M2 macrophage. Biochem. Biophys. Res. Commun. 2019, 510, 565-572. [CrossRef] [PubMed]

372. de Couto, G.; Gallet, R.; Cambier, L.; Jaghatspanyan, E.; Makkar, N.; Dawkins, J.F.; Berman, B.P.; Marbán, E. Exosomal MicroRNA Transfer Into Macrophages Mediates Cellular Postconditioning. Circulation 2017, 136, 200-214. [CrossRef]

373. Zhao, J.; Li, X.; Hu, J.; Chen, F.; Qiao, S.; Sun, X.; Gao, L.; Xie, J.; Xu, B. Mesenchymal stromal cell-derived exosomes attenuate myocardial ischaemia-reperfusion injury through miR-182-regulated macrophage polarization. Cardiovasc. Res. 2019, 115, 1205-1216. [CrossRef]

374. Lankford, K.L.; Arroyo, E.J.; Nazimek, K.; Bryniarski, K.; Askenase, P.W.; Kocsis, J.D. Intravenously delivered mesenchymal stem cell-derived exosomes target M2-type macrophages in the injured spinal cord. PLoS ONE 2018, 13, e0190358. [CrossRef]

375. Beg, F.; Wang, R.; Saeed, Z.; Devaraj, S.; Masoor, K.; Nakshatri, H. Inflammation-associated microRNA changes in circulating exosomes of heart failure patients. BMC Res. Notes 2017, 10, 1-6. [CrossRef] [PubMed]

376. Wang, C.; Zhang, C.; Liu, L.; A, X.; Chen, B.; Li, Y.; Du, J. Macrophage-Derived mir-155-Containing Exosomes Suppress Fibroblast Proliferation and Promote Fibroblast Inflammation during Cardiac Injury. Mol. Ther. 2017, 25, 192-204. [CrossRef] [PubMed]

377. Gao, W.; Liu, H.; Yuan, J.; Wu, C.; Huang, D.; Ma, Y.; Zhu, J.; Ma, L.; Guo, J.; Shi, H.; et al. Exosomes derived from mature dendritic cells increase endothelial inflammation and atherosclerosis via membrane TNF $-\alpha$ mediated NF $-\kappa B$ pathway. J. Cell. Mol. Med. 2016, 20, 2318-2327. [CrossRef]

378. Bureau, U.C. Statistical Abstract of the United States 2012. Available online: http://www.census.gov/library/publications/2011 / compendia/statab/131ed.html (accessed on 31 July 2021).

379. Riggs, B.L.; Melton, I.J. Thin bones may break without sticks or stones. Trends Endocrinol. Metabol. 1996, 7, 152-153.

380. Osteoporosis I The Second Fifty Years: Promoting Health and Preventing Disability I The National Academies Press. Available online: https: / / www.nap.edu/read/1578/chapter/8 (accessed on 23 April 2021).

381. van der Eerden, B.C. MicroRNAs in the skeleton: Cell-restricted or potent intercellular communicators? Arch. Biochem. Biophys. 2014, 561, 46-55. [CrossRef]

382. Xie, Y.; Chen, Y.; Zhang, L.; Ge, W.; Tang, P. The roles of bone-derived exosomes and exosomal microRNAs in regulating bone remodelling. J. Cell. Mol. Med. 2017, 21, 1033-1041. [CrossRef]

383. Claes, L.; Recknagel, S.; Ignatius, A. Fracture healing under healthy and inflammatory conditions. Nat. Rev. Rheumatol. 2012, 8 , 133-143. [CrossRef]

384. Cui, Y.; Luan, J.; Li, H.; Zhou, X.; Han, J. Exosomes derived from mineralizing osteoblasts promote ST2 cell osteogenic differentiation by alteration of microRNA expression. FEBS Lett. 2016, 590, 185-192. [CrossRef] [PubMed] 
385. Kuang, M.-J.; Huang, Y.; Zhao, X.-G.; Zhang, R.; Ma, J.-X.; Wang, D.-C.; Ma, X.-L. Exosomes derived from Wharton's jelly of human umbilical cord mesenchymal stem cells reduce osteocyte apoptosis in glucocorticoid-induced osteonecrosis of the femoral head in rats via the miR-21-PTEN-AKT signalling pathway. Int. J. Biol. Sci. 2019, 15, 1861-1871. [CrossRef] [PubMed]

386. Li, D.; Liu, J.; Guo, B.; Liang, C.; Dang, L.; Lu, C.; He, X.; Cheung, H.Y.-S.; Xu, L.; Lu, C.; et al. Osteoclast-derived exosomal miR-214-3p inhibits osteoblastic bone formation. Nat. Commun. 2016, 7, 10872. [CrossRef]

387. Qin, Y.; Peng, Y.; Zhao, W.; Pan, J.; Ksiezak-Reding, H.; Cardozo, C.; Wu, Y.; Pajevic, P.D.; Bonewald, L.F.; Bauman, W.A.; et al. Myostatin inhibits osteoblastic differentiation by suppressing osteocyte-derived exosomal microRNA-218: A novel mechanism in muscle-bone communication. J. Biol. Chem. 2017, 292, 11021-11033. [CrossRef] [PubMed]

388. Ren, L.; Song, Z.-J.; Cai, Q.-W.; Chen, R.-X.; Zou, Y.; Fu, Q.; Ma, Y.-Y. Adipose mesenchymal stem cell-derived exosomes ameliorate hypoxia/serum deprivation-induced osteocyte apoptosis and osteocyte-mediated osteoclastogenesis in vitro. Biochem. Biophys. Res. Commun. 2019, 508, 138-144. [CrossRef]

389. Sun, W.; Zhao, C.; Li, Y.; Wang, L.; Nie, G.; Peng, J.; Wang, A.; Zhang, P.; Tian, W.; Li, Q.; et al. Osteoclast-derived microRNAcontaining exosomes selectively inhibit osteoblast activity. Cell Discov. 2016, 2, 16015. [CrossRef] [PubMed]

390. Yang, J.-X.; Xie, P.; Li, Y.-S.; Wen, T.; Yang, X.-C. Osteoclast-derived miR-23a-5p-containing exosomes inhibit osteogenic differentiation by regulating Runx2. Cell. Signal. 2020, 70, 109504. [CrossRef]

391. Xu, J.-F.; Yang, G.-H.; Pan, X.-H.; Zhang, S.-J.; Zhao, C.; Qiu, B.-S.; Gu, H.-F.; Hong, J.-F.; Cao, L.; Chen, Y.; et al. Altered MicroRNA Expression Profile in Exosomes during Osteogenic Differentiation of Human Bone Marrow-Derived Mesenchymal Stem Cells. PLoS ONE 2014, 9, e114627. [CrossRef]

392. Lu, Z.; Chen, Y.; Dunstan, C.; Roohani-Esfahani, S.; Zreiqat, H. Priming Adipose Stem Cells with Tumor Necrosis Factor-Alpha Preconditioning Potentiates Their Exosome Efficacy for Bone Regeneration. Tissue Eng. Part A 2017, 23, 1212-1220. [CrossRef]

393. Zhang, J.; Liu, X.; Li, H.; Chen, C.; Hu, B.; Niu, X.; Li, Q.; Zhao, B.; Xie, Z.; Wang, Y. Exosomes/tricalcium phosphate combination scaffolds can enhance bone regeneration by activating the PI3K/Akt signaling pathway. Stem Cell Res. Ther. 2016, 7, 1-14. [CrossRef]

394. Cappariello, A.; Loftus, A.; Muraca, M.; Maurizi, A.; Rucci, N.; Teti, A. Osteoblast-Derived Extracellular Vesicles Are Biological Tools for the Delivery of Active Molecules to Bone. J. Bone Miner. Res. 2018, 33, 517-533. [CrossRef]

395. Huynh, N.; VonMoss, L.; Smith, D.; Rahman, I.; Felemban, M.; Zuo, J.; Rody, J.W.; McHugh, K.; Holliday, L. Characterization of Regulatory Extracellular Vesicles from Osteoclasts. J. Dent. Res. 2016, 95, 673-679. [CrossRef]

396. Furuta, T.; Miyaki, S.; Ishitobi, H.; Ogura, T.; Kato, Y.; Kamei, N.; Miyado, K.; Higashi, Y.; Ochi, M. Mesenchymal Stem Cell-Derived Exosomes Promote Fracture Healing in a Mouse Model. Stem Cells Transl. Med. 2016, 5, 1620-1630. [CrossRef]

397. Zhang, S.; Chu, W.; Lai, R.C.; Lim, S.K.; Hui, J.H.P.; Toh, W. Exosomes derived from human embryonic mesenchymal stem cells promote osteochondral regeneration. Osteoarthr. Cartil. 2016, 24, 2135-2140. [CrossRef] [PubMed]

398. Grundnes, O.; Reikeraas, O. Effects of macrophage activation on bone healing. J. Orthop. Sci. 2000, 5, 243-247. [CrossRef]

399. Schmidt-Bleek, K.; Schell, H.; Schulz, N.; Hoff, P.; Perka, C.; Buttgereit, F.; Volk, H.-D.; Lienau, J.; Duda, G.N. Inflammatory phase of bone healing initiates the regenerative healing cascade. Cell Tissue Res. 2011, 347, 567-573. [CrossRef] [PubMed]

400. Yu, B.; Zhang, X.; Li, X. Exosomes Derived from Mesenchymal Stem Cells. Int. J. Mol. Sci. 2014, 15, 4142-4157. [CrossRef] [PubMed]

401. Chen, W.; Huang, Y.; Han, J.; Yukai, H.; Li, Y.; Lu, Z.; Li, H.; Liu, Z.; Shi, C.; Duan, F.; et al. Immunomodulatory effects of mesenchymal stromal cells-derived exosome. Immunol. Res. 2016, 64, 831-840. [CrossRef]

402. Zhang, W.; Wray, L.S.; Rnjak-Kovacina, J.; Xu, L.; Zou, D.; Wang, S.; Zhang, M.; Dong, J.; Li, G.; Kaplan, D.L.; et al. Vascularization of hollow channel-modified porous silk scaffolds with endothelial cells for tissue regeneration. Biomaterials 2015, 56, 68-77. [CrossRef]

403. Deregibus, M.C.; Cantaluppi, V.; Calogero, R.; Lo Iacono, M.; Tetta, C.; Biancone, L.; Bruno, S.; Bussolati, B.; Camussi, G. Endothelial progenitor cell-derived microvesicles activate an angiogenic program in endothelial cells by a horizontal transfer of mRNA. Blood 2007, 110, 2440-2448. [CrossRef]

404. Bian, S.; Zhang, L.; Duan, L.; Wang, X.; Min, Y.; Yu, H. Extracellular vesicles derived from human bone marrow mesenchymal stem cells promote angiogenesis in a rat myocardial infarction model. J. Mol. Med. 2014, 92, 387-397. [CrossRef]

405. Zhang, H.; Liu, X.-B.; Huang, S.; Bi, X.-Y.; Wang, H.-X.; Xie, L.-X.; Wang, Y.-Q.; Cao, X.-F.; Lv, J.; Xiao, F.-J.; et al. Microvesicles Derived from Human Umbilical Cord Mesenchymal Stem Cells Stimulated by Hypoxia Promote Angiogenesis Both In Vitro and In Vivo. Stem Cells Dev. 2012, 21, 3289-3297. [CrossRef] [PubMed]

406. Xie, H.; Wang, Z.; Zhang, L.; Lei, Q.; Zhao, A.; Wang, H.; Li, Q.; Cao, Y.; Zhang, W.J.; Chen, Z. Extracellular Vesicle-functionalized Decalcified Bone Matrix Scaffolds with Enhanced Pro-angiogenic and Pro-bone Regeneration Activities. Sci. Rep. 2017, 7, srep45622. [CrossRef] [PubMed]

407. Qi, X.; Zhang, J.; Yuan, H.; Xu, Z.; Li, Q.; Niu, X.; Hu, B.; Wang, Y.; Li, X. Exosomes Secreted by Human-Induced Pluripotent Stem Cell-Derived Mesenchymal Stem Cells Repair Critical-Sized Bone Defects through Enhanced Angiogenesis and Osteogenesis in Osteoporotic Rats. Int. J. Biol. Sci. 2016, 12, 836-849. [CrossRef] [PubMed]

408. Wei, J.; Li, H.; Wang, S.; Li, T.; Fan, J.; Liang, X.; Li, J.; Han, Q.; Zhu, L.; Fan, L.; et al. let-7 Enhances Osteogenesis and Bone Formation While Repressing Adipogenesis of Human Stromal/Mesenchymal Stem Cells by Regulating HMGA2. Stem Cells Dev. 2014, 23, 1452-1463. [CrossRef] 
409. Xu, S.; Santini, G.C.; De Veirman, K.; Broek, I.V.; Leleu, X.; De Becker, A.; Van Camp, B.; Vanderkerken, K.; Van Riet, I. Upregulation of miR-135b Is Involved in the Impaired Osteogenic Differentiation of Mesenchymal Stem Cells Derived from Multiple Myeloma Patients. PLoS ONE 2013, 8, e79752. [CrossRef] [PubMed]

410. Bakhshandeh, B.; Hafizi, M.; Ghaemi, N.; Soleimani, M. Down-regulation of miRNA-221 triggers osteogenic differentiation in human stem cells. Biotechnol. Lett. 2012, 34, 1579-1587. [CrossRef] [PubMed]

411. Sun, Y.; Xu, L.; Huang, S.; Hou, Y.; Liu, Y.; Chan, K.-M.; Pan, X.-H.; Li, G. mir-21 Overexpressing Mesenchymal Stem Cells Accelerate Fracture Healing in a Rat Closed Femur Fracture Model. BioMed Res. Int. 2015, 2015, 412327. [CrossRef]

412. Li, H.; Liang, A.; Yang, F.; Wang, Z.; Fu, Q. MicroRNA-21 promotes osteogenic differentiation by targeting small mothers against decapentaplegic 7. Mol. Med. Rep. 2012, 12, 1561-1567. [CrossRef]

413. Meng, Y.-B.; Li, X.; Li, Z.-Y.; Zhao, J.; Yuan, X.-B.; Ren, Y.; Cui, Z.-D.; Liu, Y.-D.; Yang, X.-J. microRNA-21 promotes osteogenic differentiation of mesenchymal stem cells by the PI3K/ $\beta$-catenin pathway. J. Orthop. Res. 2015, 33, 957-964. [CrossRef]

414. Chan, J.F.-W.; Yuan, S.; Kok, K.-H.; To, K.K.-W.; Chu, H.; Yang, J.; Xing, F.; Liu, J.; Yip, C.C.-Y.; Poon, R.W.-S.; et al. A familial cluster of pneumonia associated with the 2019 novel coronavirus indicating person-to-person transmission: A study of a family cluster. Lancet 2020, 395, 514-523. [CrossRef]

415. Wu, F.; Zhao, S.; Yu, B.; Chen, Y.-M.; Wang, W.; Song, Z.-G.; Hu, Y.; Tao, Z.-W.; Tian, J.-H.; Pei, Y.-Y.; et al. A new coronavirus associated with human respiratory disease in China. Nature 2020, 579, 265-269. [CrossRef]

416. Zhu, N.; Zhang, D.; Wang, W.; Li, X.; Yang, B.; Song, J.; Zhao, X.; Huang, B.; Shi, W.; Lu, R.; et al. A Novel Coronavirus from Patients with Pneumonia in China, 2019. N. Engl. J. Med. 2020, 382, 727-733. [CrossRef] [PubMed]

417. Chin, A.W.H.; Chu, J.T.S.; Perera, M.R.A.; Hui, K.P.Y.; Yen, H.-L.; Chan, M.C.W.; Peiris, M.; Poon, L.L.M. Stability of SARS-CoV-2 in different environmental conditions. Lancet Microbe 2020, 1, e10. [CrossRef]

418. Bernardo, M.E.; Fibbe, W.E. Mesenchymal Stromal Cells: Sensors and Switchers of Inflammation. Cell Stem Cell 2013, 13, 392-402. [CrossRef]

419. DelaRosa, O.; Sánchez-Correa, B.; Morgado, S.; Ramírez, C.; Del Río, B.; Menta, R.; Lombardo, E.; Tarazona, R.; Casado, J.G. Human Adipose-Derived Stem Cells Impair Natural Killer Cell Function and Exhibit Low Susceptibility to Natural KillerMediated Lysis. Stem Cells Dev. 2012, 21, 1333-1343. [CrossRef] [PubMed]

420. Raffaghello, L.; Bianchi, G.; Bertolotto, M.B.; Montecucco, F.; Busca, A.; Dallegri, F.; Ottonello, L.C.; Pistoia, V. Human Mesenchymal Stem Cells Inhibit Neutrophil Apoptosis: A Model for Neutrophil Preservation in the Bone Marrow Niche. Stem Cells 2008, 26, 151-162. [CrossRef] [PubMed]

421. Hoffmann, M.; Kleine-Weber, H.; Krüger, N.; Müller, M.; Drosten, C.; Pöhlmann, S. The novel coronavirus 2019 (2019-ncov) uses the sars-coronavirus receptor ace2 and the cellular protease tmprss2 for entry into target cells. bioRxiv 2020. [CrossRef]

422. Li, F.; Li, W.; Farzan, M.; Harrison, S.C. Structure of SARS Coronavirus Spike Receptor-Binding Domain Complexed with Receptor. Science 2005, 309, 1864-1868. [CrossRef] [PubMed]

423. Leng, Z.; Zhu, R.; Hou, W.; Feng, Y.; Yang, Y.; Han, Q.; Shan, G.; Meng, F.; Du, D.; Wang, S.; et al. Transplantation of ACE2Mesenchymal Stem Cells Improves the Outcome of Patients with COVID-19 Pneumonia. Aging Dis. 2020, 11, 216-228. [CrossRef]

424. Liang, B.; Chen, J.; Li, T.; Wu, H.; Yang, W.; Li, Y.; Li, J.; Yu, C.; Nie, F.; Ma, Z.; et al. Clinical remission of a critically ill COVID-19 patient treated by human umbilical cord mesenchymal stem cells. Medicine 2020, 99, 1-6. [CrossRef]

425. Li, X.; Liu, L.; Yang, J.; Yu, Y.; Chai, J.; Wang, L.; Ma, L.; Yin, H. Exosome Derived From Human Umbilical Cord Mesenchymal Stem Cell Mediates MiR-181c Attenuating Burn-induced Excessive Inflammation. EBioMedicine 2016, 8, 72-82. [CrossRef] [PubMed]

426. Long, Q.; Upadhya, D.; Hattiangady, B.; Kim, D.-K.; An, S.Y.; Shuai, B.; Prockop, D.J.; Shetty, A.K. Intranasal MSC-derived A1-exosomes ease inflammation, and prevent abnormal neurogenesis and memory dysfunction after status epilepticus. Proc. Natl. Acad. Sci. USA 2017, 114, E3536-E3545. [CrossRef] [PubMed]

427. Batrakova, E.V.; Kim, M. Using exosomes, naturally-equipped nanocarriers, for drug delivery. J. Control. Release 2015, 219, 396-405. [CrossRef] [PubMed] 